\title{
An integrated material flows, stakeholders and policies approach to identify and exploit regional resource potentials
}

Rebekka Volk $^{(\mathrm{a})^{*}}$, Richard Müller ${ }^{(a)}$, Joachim Reinhardt ${ }^{(\mathrm{b})}$, Frank Schultmann ${ }^{(\mathrm{a})}$

(a) Karlsruhe Institute of Technology (KIT), Institute for Industrial Production (IIP), Hertzstr. 16, 76187 Karlsruhe, Germany

(b) ifeu Institut für Energie und Umweltforschung Heidelberg GmbH

* corresponding author: rebekka.volk@kit.edu

\begin{abstract}
Material flows in the construction and demolition (C\&D) sector remain high in many countries. But, their changes or reductions are essential for successful circular economies. Existing material flow analyses do not cover regional characteristics, stakeholders and impacts of policy measures and interactions.

We contribute a new, unprecedented way of integrating regional building and infrastructure material stock and flow modelling with stakeholders, policy measures, their impacts and mutual interactions. Stakeholders are considered with their objectives, influences, interactions, willingness to act, to cooperate or contribute to resource conservation. 31 policy measures are crystallized from literature and evaluated in two surveys regarding their expected impact, their bundling and temporal effects. The integrated bottom-up simulation model was tested for the federal state of Baden-Württemberg (Germany).

The results show that until 2030 net stock piling can be expected and secondary raw materials from building stock will be sufficient to supply future recycling concrete production until 2030. Most
\end{abstract}


effective policy measures are additional cost/taxes on primary resources, increased disposal fees and curriculae adaption. Bundling these leads to a combined RESPOT of $30.8 \%$. The results are useful for political decision makers, educational institutions, disposal site operators as well as primary and secondary raw material extraction industries.

Key words: Material flow analysis; stakeholder analysis; stakeholder model; resource efficiency; reduced environmental impact; construction and demolition sector; policy recommendations

\section{Introduction}

Due to high volumes ${ }^{1}$, construction and deconstruction (C\&D) waste plays an important role in the transition to a circular economy in industrialized countries. In some countries high volumes of C\&D waste are processed and "recycled" in road works². In other both industrialized and developing countries, high shares of C\&D waste are still disposed in landfills (Jin et al. 2017) and motivate research, industry and politics for resource conservation actions. However, in many countries closed-loop recycling and circular economy is envisioned for future sustainable development and resource management (Schiller et al. 2017a). Closed-loop recycling refers to the collection, sorting and processing of post-consumer products to new products of the same kind. Especially for C\&D waste, recycling leads to significant reductions in emissions, energy use, global warming potential and landfill space (Marzouk and Azab 2014, p. 41).

\footnotetext{
${ }^{1}$ For example, in Germany, the relative share of the C\&D waste fraction lowered since 2000 from $64 \%$ to $52 \%$ (UBA (2018b)). The total amount decreased from 261 million tons in 2000 (64\%) to 185 million tons in 2005 (55\% share), but then increased again to 208 million tons in 2015 (52\%).208 of 402 million tons results from the sector in 2015 constituting $52 \%$ of the total annual waste generation (equals 2.5 per capita) (DESTATIS (2015)). Newer data show ca. 224 Mio. tons of C\&D waste in 2016 (53.7\%, total: 417 million tons of waste) (Statistikportal 2019a). About 25\% origins in debris from demolished buildings and infrastructure, whereas ca. $60 \%$ are excavated material and ca. $7 \%$ are road construction wastes (KRW-Bau (2017), p.6). In Germany, the C\&D waste material recycling rate is $89 \%$, including backfilling (Destatis (2017b)). $50.9 \%$ of the total waste and thus most C\&D waste and excavated material is in recycled by non-thermal recycling plants (without backfilling or landfill disposal) (Statistikportal 2019b). But, C\&D waste amounts and recycling rates stagnated in recent years and followed the economic development of the construction industry up to now (UBA (2018b,c)) instead of decoupling from economic development.

${ }^{2}$ In 2010, ca. 52\% of secondary construction materials in Germany stem from other sectors and 46\% from waste treatment/ recycling of former construction materials/ deconstruction waste (Schiller et al. 2015, p. 179).
} 
An European action plan ${ }^{3}$ for circular economy defines recycling rates of $70 \%$ until 2020 for all waste fractions, not only but also in the C\&D sector. Current strategies for resource efficiency in the C\&D sector aim at cutting emissions, reducing waste, land-use, dependencies on scarce materials (European Commission 2014) and decoupling of C\&D waste generation and economic growth (GDP) (Destatis (2018b), p. 30). Remaining problems are high C\&D waste streams, high demands for primary building materials and down-cycling ${ }^{4}$ problems. And, increasing energetic building requirements, limited primary resources and increasing raw materials prices, limited disposal sites and capacities, low transportation ranges $(<25 \mathrm{~km})^{5}$ and regionally differing demographic and structural developments demand for regionally adapted resource management strategies.

A number of C\&D material flow analysis (MFA) approaches were already developed, mostly on national level (e.g. Schiller et al. 2017a,b; Tanikawa et al. 2015; Augiseau and Barles 2017). As transportation of bulky C\&D waste and recycling material is comparably costly, analyses and measures on regional level are required for change. Thus, economically feasible closed-loop reuse and recycling potentials are highest on regional level (<50 km range) (Schiller et al. 2017a, p.121).

Thus, a detailed, regional analysis and projection of impacts of buildings and infrastructure on energy and especially material stocks and flows in the anthropogenic sphere as well as their sustainability is required (Schiller et al. 2010, Deilmann et al. 2014) and already provided by latest works on county ${ }^{6}$ level (e.g. Schiller et al. 2017a, Hiete et al. 2011). Especially, regional impacts (in particular around cities) like land use conflicts and scarcity of local resources should be considered (Augiseau and Barles (2017), p. 153; Wu et al. 2014, p. 1686) as well as local cultural, socio-economic, environmental and political particularities (Menegaki and Damigos (2018), p. 13).

Basic requirement for a high-quality resource management is a detailed knowledge about the stock, the amount, location and time of waste generation, its quality and purity, and the cost for its recovery

\footnotetext{
${ }^{3}$ Closing the loop - An EU action plan for the Circular Economy, https://eurlex.europa.eu/resource.html?uri=cellar:8a8ef5e8-99a0-11e5-b3b7-01aa75ed71a1.0012.02/DOC 1\&format=PDF, last access: 13 June 2018.

4 Use of processed C\&D waste fractions in road construction, dams, fillings, etc. instead of the original use, e.g. in buildings.

${ }^{5}$ Schiller et al. 2010, Hiete et al., 2011. The upper limit of economic feasible transport distances is considered to be $50-$ $70 \mathrm{~km}$ (Knappe and Lansche 2010, Schebek et al. 2017).

${ }^{6}$ County and urban/rural district is used synonymously in this article.
} 
(Clement et al. 2009). Due to lacking precise data on material composition of the building and infrastructure stock, the total amount of the different waste fractions and the trends of their development can often only roughly be assumed. An extensive raw material cadastre is lacking.

Like in every C\&D project, many stakeholders in the C\&D sector are involved with their differing objectives, diverging interests and willingness for cooperation (BBSR 2015b). The resulting stakeholder motivations, goal and interest conflicts and their consequences are challenging and not yet fully analysed in research (Abarca-Guerrero et al. 2017, Park and Tucker 2017, Jin et al. 2017, Knoeri et al. 2011), considered by policy makers or connected with material flow models. Furthermore, there is a need to consider willingness to act and policy impacts to reduce C\&D waste and enable higher quality reuse, recycling and management of the respective material fractions.

Policy impacts of different resource conservation measures and industrial ecology policies to reduce resource depletion and enhance circular economy haven't been fully investigated, such as "closing of material flows, [...] dematerialisation of products and economic activities, [...] development of local recovery industries, [...] incentives and coercive measures [...], R\&D subsidies, labelling, training, taxes, or adaptation of construction standards [...]" (Augiseau and Barles 2017, p. 162). Also, their reinforcing or hampering effects or timely developments haven't been studied thoroughly.

This study aims at investigating the impact of stakeholder modelling and policies on conventional C\&D waste and material flow analyses and to derive consequences for national and regional resource policy in different development scenarios. As circular economy is increasingly important to decouple resource consumption and depletion from economic growth and income, a methodology and tool for analysis and future projections is needed. The innovation and original contribution of this study is the combination of the material flow modelling and the stakeholder perspective modelling to analyse the impacts of C\&D avoidance, recycling and management policies. This can be used to answer a wide range of questions that are of importance to support circular economy. To the authors, no similar approach is known.

Addressees of the study are stakeholders of C\&D industry, political decision makers and academia that are interested in future C\&D waste and resource management on national and regional level, 
education of C\&D professionals and the development of secondary resource markets in this sector. Also, operators of landfills and investors in C\&D recycling technology are interested in projected scenarios of future C\&D waste and material flows.

Thus, the imposed research questions in this study are:

- How can the total environmental impact of C\&D waste be minimized on county and regional level (measured in differentiated waste streams and RC material demand matching)?

- How can resource demands and RC material supply developments be projected and lowered until $2030 ?$

- Which policy measures for resource efficiency and industrial ecology are most promising to realise a sustainable, regional circular economy in the C\&D industry?

In the following, this work reviews existing literature (section 2) and defines the research approach (section 3). Focus of the study is the description of the developed model with its model structure, material flow model, stakeholder data generation and measure modelling, the mathematical formulation and the considered scenarios (section 4). A case study for the German federal state of Baden-Württemberg (BW) demonstrates the model application (section 5). Finally, a discussion (section 6) and a research outlook is given (section 7).

\section{Review of literature}

Literature can be differentiated into deductive (top-down) and inductive (bottom-up) approaches (Schiller et al. 2017a, p. 119f.). Furthermore, quantitative approaches based on inflows and outflows (ibidem) and qualitative stakeholder research can be distinguished. We differentiate also approaches of material stock and flow modelling and waste flow modelling (section 2.1) from stakeholder analyses and modelling (section 2.2.). 


\subsection{Resource, material and waste modelling of building and infrastructure stocks}

Plenty of works classify the building stock according to its energetic characteristics (IWU 2005, 2011, 2012). Building stock models coping with material stocks and flows are less available (Naber et al. 2017), but are increasing (Wu et al. 2014; Dürkoop et al. 2016). Bottom-up models are common, facing challenges of data aggregation and (pre)processing, the building heterogeneity and incomplete documentation (Naber et al. 2017). Song et al. 2017 divide existing studies into the categories of management strategies or qualitative analysis, quantified modelling and technical analysis.

Existing studies aim at estimating present or forecasting future stocks, input and output material flows and parameters' influence on future flows (Augiseau and Barles 2017, p. 153). Most works aim at accounting; only few are used for simulation (Naber et al. 2017) or to investigate the causes or drivers of stock accumulation (Fishman et al. 2015). Only very few models focus on answering the challenges of circular economy, e.g. by matching spatially localized material supply and demand (e.g. Hiete et al. 2011, Schiller et al. 2017a,b).

A search in the sciencedirect database for the keywords „building stock material“ resulted in more than $75,000^{7}$ items. The search for "building stock construction material“ still resulted in more than 22,000 items, consisting of review articles $(>1,600)$, research papers $\left(>21,200^{8}\right)$ and data articles $(7)$. Many of these research papers are published in energy-related journals ${ }^{9}$. Further relevant papers were found in the web-of-science database with the key words "building material flow analysis", "building stock", "construction waste" and "urban mining". Here, only the most important studies ${ }^{10}$ are

\footnotetext{
${ }^{7}$ Thereof, between 1995-2005 ca. 1,100-1,700 items, between 2006-2011 (ca. 2,000-2,500 items) and between 2012-today $(3,000-5,300$ items), the number of research contributions is strongly increasing, especially in the last 3 years.

${ }^{8}$ Thereof, research papers sum up to $>13,300$ in the last 10 years. And, at least $>2380$ contributions (of the basic search with $>21,200$ results) are published in energy-related journals: Energy and Buildings (692), Energy Policy (677), Renewable and Sustainable Energy Reviews (383), Energy Procedia (351), and Energy (279).

${ }^{9}$ In the most frequent journals, 13,300 journal papers of the last 10 years distribute as follows: Energy and Buildings (610), Journal of Cleaner Production (539), Energy Policy (444), Construction and Building Materials (401), Renewable and Sustainable Energy Reviews (363), Energy Procedia (351), Procedia Engineering (271), Applied Energy (201), Building and Environment (201) and Resources, Conservation and Recycling (190).

10 Predominantly, German research is cited here due to the focus on a German case study region (Baden-Württemberg) (see section 5). For an overview on international research in the field see Augiseau and Barles (2017) and Wu et al. (2014) (C\&D stock and flow models) as well as Müller et al. (2014) and Tanikawa et al. (2015) (mainly metal stocks and flows).
} 
described and reviewed (see Table 1, Table 2). A comprehensive review of 57 studies on building stock and C\&D waste quantification approaches and their applied methods is performed by Wu et al. (2014).

Table 1: Overview on research areas in material stock and flow analyses of the C\&D sector

\begin{tabular}{|l|l|}
\hline Research area & Literature in the field \\
\hline $\begin{array}{l}\text { Residential buildings } \\
\text { (RBs) }\end{array}$ & $\begin{array}{l}\text { Görg 1997; Klauß et al. 2009; Schiller et al. 2010; Gruhler and Böhm 2011a; } \\
\text { Deilmann et al. 2014; Schiller et al. 2017a,b; IÖR 2018; Gontia et al. 2018 }\end{array}$ \\
\hline $\begin{array}{l}\text { Non-residential } \\
\text { buildings (NRBs) }\end{array}$ & $\begin{array}{l}\text { Görg 1997; Gruhler and Böhm 2011b; Dirlich et al. 2011; Deilmann et al. } \\
\text { 2013, 2014; Schebek et al. 201711; Ortlepp et al. 2016, 2017; ÖR 2018 }\end{array}$ \\
\hline Districts & Naber et al. 2017 \\
\hline $\begin{array}{l}\text { Cities, megacities and } \\
\text { urban/metropolitan } \\
\text { areas }\end{array}$ & $\begin{array}{l}\text { Barles 2009; Zhao et al. 2010; De Melo et al. 2011; Rechberger and } \\
\text { Clement 2011; Lu and Tam 2013; Ding and Xiao 2014; Kleemann et al. } \\
\text { 2015; Tanikawa and Hashimoto 2009; Wu et al. 2016a,b; Yang et al. 2017; } \\
\text { Condeixa et al. 2017; Schebek et al. 2017; Mastrucci et al. 2017; Stephan } \\
\text { and Athanassiadis 2018; Wang et al. 2018 }\end{array}$ \\
\hline Remote areas & $\begin{array}{l}\text { Crawford et al. 2017 } \\
\text { Regional areas } \\
\text { eüller et al. 2004 (only timber); Barles 2014; Hassan et al. 2012; Serrand } \\
\text { 2015; Daxbeck et al. 2015; Schiller et al. 2016, 2017a,b }\end{array}$ \\
\hline $\begin{array}{l}\text { National material } \\
\text { stocks and flows }\end{array}$ & $\begin{array}{l}\text { Kohler and Hassler 2002; Buchert et al. 2004; Cochran et al. 2007; Kohler } \\
\text { and Yang 2007; Yang and Kohler 2008; Schiller et al. 2010, 2015, 2017b,c; } \\
\text { Coelho and de Brito 2011a,b; Deilmann et al. 2014; Oyedele et al. 2014; } \\
\text { Wu et al. 2014 (Review); Duan et al. 2015; Tanikawa et al. 2015; Hong et } \\
\text { al. 2016; Lu et al. 2016; Ortlepp et al. 2016; Abarca-Guerrero et al. 2017; } \\
\text { Ajayi and Oyedele 2017; Jin et al. 2017; Schiller et al. 2017a,b; Ortlepp et } \\
\text { al. 2017; Polat et al. 2017; Zheng et al. 2017; Ortlepp et al. 2018 }\end{array}$ \\
\hline $\begin{array}{l}\text { National C\&D material } \\
\text { flows (only) }\end{array}$ & Marzouk and Azab 2014, Abdelhamid 2014, Song et al. 2017 \\
\hline
\end{tabular}

The most capable urban material metabolism model in Germany considers material stocks and flows analyses and their dynamics in buildings, infrastructures and other durable capital and consumer goods $^{12}$ (Schiller et al. 2010, 2015, 2017a,b,c). They analyse top down economic development and bottom up analyses of product-related material indicators and combine it with waste fraction analyses. However, between top down and bottom up approaches there is still a major gap (Schiller et al. 2015, p. LI), e.g. due to unavailable data. The model distinguishes six structurally different county types of

\footnotetext{
${ }^{11}$ Schebek et al (2017) developed a method to inventory non-residential buildings in a German case study metropolitan area to provide more insight into typical gross volumes, construction periods and building uses (functions). They found that ca. 33\% of the considered 19 non-residential buildings originate before 1948 (so retrofitting is important for future use) and specific material contents vary largely (p.24). But, they could not provide the retrofit status of the buildings (p.28).

${ }^{12}$ Durable capital and consumer goods are not further specified by only categorized into their material (predominantly made from metal, non-metal, biomass or plastics).
} 
urban areas, suburban and rural areas with higher or lower dynamics in Eastern and Western Germany. Also, they show that county level is reasonable from an economic point of view with on average a diameter of $32 \mathrm{~km}$ per county and thus with reasonable respective transportation distances (Schiller et al. 2017a, p. 121, based on Buchert et al. 2004, Schiller et al. 2010). The implementation in the DyMAS model envisions a localized material stock and flows per rural/urban districts, but data are missing yet (Hedemann et al. 2017). The latest approach of Schiller et al. 2017a,b provides a national model for Germany with a high spatial resolution (on county level) and is based on a bottom-up approach using material composition indicators (see also Ortlepp et al. 2016, 2018). They calculate inflows and outflows of the residential and non-residential building stock as a function of the population development, the technology applied in capture, processing and admixture. Also, they reveal the loss of material due to processing and sorting technologies (Schiller et al. 2017a, p. 123-126). However, major drawbacks are the restriction of demand and supply matching only within counties, the lack of retrofitting ${ }^{13}$ activities, the focus on masonry and concrete recycling only, the lacking modelling of road infrastructure or other sectors and the old data base from 2005 and 2009 (Schiller et al. 2017a, p.121; Schiller et al. 2017b, p. 679).

Deilmann et al. (2013) use commercial geospatial information on building footprints and usage type of four German states (incl. Baden-Württemberg) and additional, typical building and storey heights to calculate net and gross areas and volumes. Open sources like open street map don't provide the necessary attributes. Further GIS related work was reviewed and done by Kleemann et al. (2016) for the city of Vienna.

Deilmann et al. (2014) project the development of building stock, C\&D waste and recycling until 2050 with different scenarios and sensitivities based on building types, statistics, recycling technologies and rates for 16 building products, material recipes and renovation cycles. They investigate business-asusual and sustainability scenarios with expert-estimated future recycling rates for the considered construction products and a projection of C\&D material flow development for 2030 and 2050 including

\footnotetext{
${ }^{13}$ They name renewal rates as a driver of new dwellings (Schiller et al. 2017b, p.675), but it is not clear if this refers to replacements or retrofitting activities.
} 
recycling technology innovations. But, they neglect technical infrastructure networks, a regional differentiation, changes in framework conditions and stakeholder decision making.

Building-related material flow analyses (MFA) were performed for single urban areas (Brunner et al. 1998), and only for some regions like Saxony (see e.g. Schiller et al. 2016) but not for BadenWürttemberg so far. Only for some counties in Northern Baden-Württemberg and neighbouring federal states ${ }^{14}$, a MFA on C\&D waste was done for residential buildings to quantify annual expected demolition material flows and minimum transport cost to recycling/treatment and disposal facilities (Hiete et al. 2011).

For modelling national C\&D material flow systems in general (without localisation or system boundaries) some approaches use system dynamics (e.g. Marzouk and Azab 2014) or statistical methods and neural networks (Song et al. 2017). System dynamics is a method to model, simulate, analyse and design dynamic and complex socio-economic systems. For a literature review of system dynamics models in the C\&D sector see Marzouk and Azab (2014), p. $42 f$.

\footnotetext{
${ }^{14}$ However, the case study region only comprises of an area of $1880 \mathrm{~km}^{2}$ and a population of 773,000 located in the northwest part of Baden-Württemberg, and has a rural character surrounded by densely populated areas.
} 
Table 2: Overview on key literature in the field as well as literature focusing on regional models (alphabetical order)

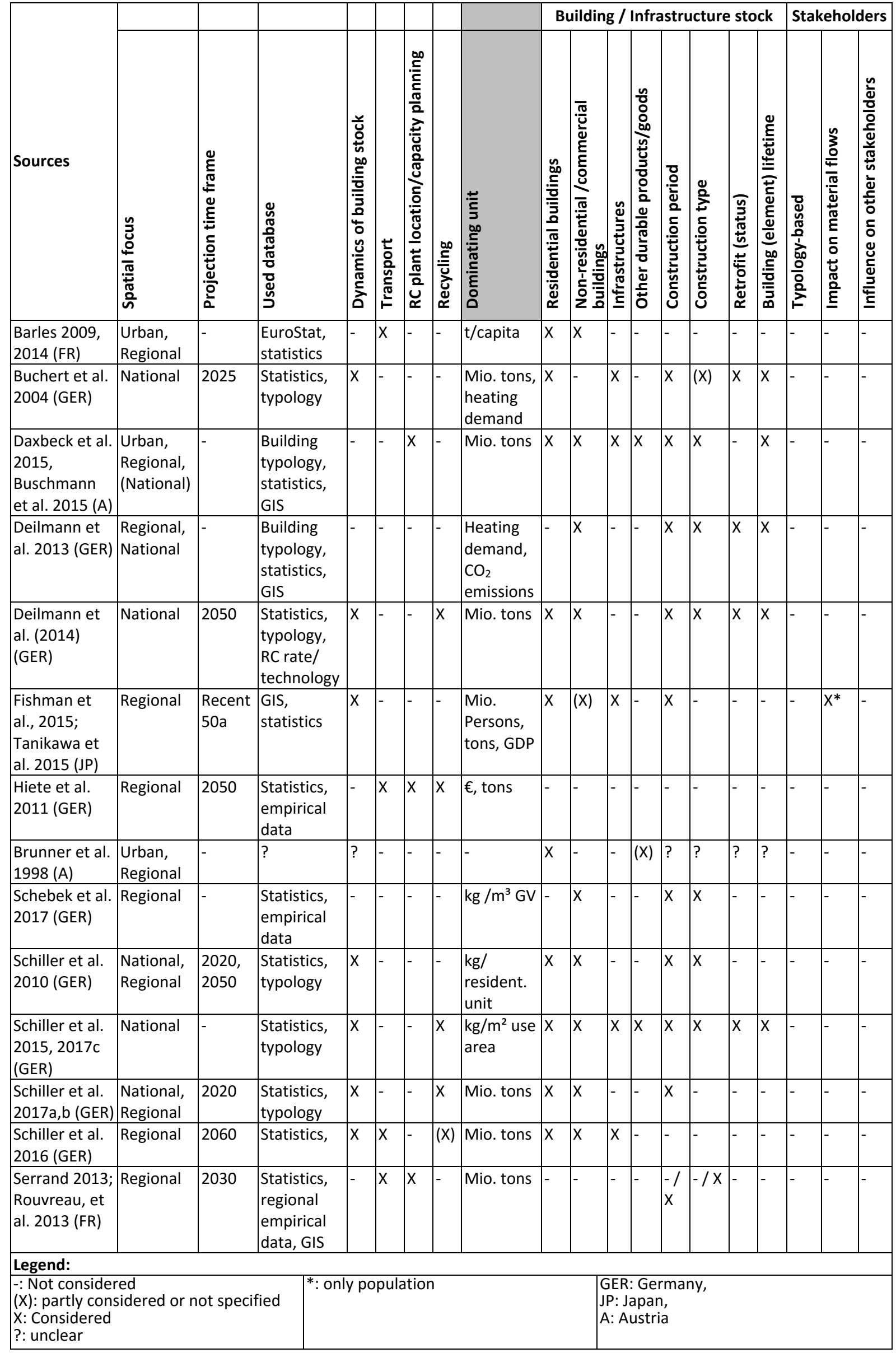




\subsection{Stakeholder perspective, policy impact and influence modelling}

General literature names qualitative and quantitative models, multi-stakeholder networks and agentbased models. Most models identify project supporters and opponents and quantify and assess the cooperation and thread potential for project success. Only few approaches of stakeholder (network) analysis for the C\&D industry were found (Knappe et al. 2012, Ajayi and Oyedele 2017).

We concentrate on quantitative approaches that consider multiple stakeholders. Very widespread are power/interest considerations according to Mitchell et al. (1997) and analyses on project level instead of urban or regional level or the C\&D sector as a whole. Existing approaches deal with stakeholder positioning, stakeholder integration, identification of qualitative cooperation potentials and conflict resolution, but neglect stakeholder interaction or networks and their influences on the whole system so far (see Table 3).

Internationally, Menegaki and Damigos (2018) as well as Ajayi and Oyedele (2017) identified barriers and motivations by literature review, semi-structured interviews, group discussions and questionnaires. In the German C\&D industry, Knappe et al. (2012) identified stakeholders, barriers for system change, interactions and mutual influences. They proposed and performed communication measures to increase dialogue and name many measures to increase resource efficiency in the C\&D sector, but neglect reinforcing or mitigating effects and measure impacts.

Only recently, literature explored construction professionals' views on effective policies for minimizing landfilling of C\&D waste for the first time (Ajayi and Oyedele 2017, p. 63). However, they refrain from quantifying impacts and investigating interdependencies of the assessed policy measures. Lu and Tam (2013) performed a longitudinal study and analysed the past policies' impact on development of C\&D waste in Hong Kong ex-post on a macro-economic level. They found that financial incentives were changing the trend and that education and an interlocking policy system is helpful to reduce C\&D waste (in particular based on a construction waste disposal charging scheme). But, they did not specify their stakeholder-based analysis and refrain from proposing future policies (Lu and Tam 2013, p.221f.). Furthermore, they face the specific situation in Hong Kong where inert C\&D waste used for land 
reclamation projects is seen as reused RC material. Abdelhamid 2014 compares two C\&D waste management approaches from different stakeholder perspectives via qualitative analysis. Different key stakeholders are identified. However, the approach is limited as material flows and costs are not quantified and the underlying database and decision support is unclear.

Table 3: Overview on applied stakeholder methods in the construction sector or related sectors

\begin{tabular}{|c|c|c|}
\hline Topic & Aims & Used method \\
\hline $\begin{array}{l}\text { - Stakeholder management in large } \\
\text { transport infrastructure projects } \\
\text { (Wadenpohl, 2011) } \\
\text { - Evaluation of stakeholder influence in } \\
\text { the implementation of construction } \\
\text { projects (Olander and Landin, 2005) } \\
\text { - Comparative study of factors affecting } \\
\text { the external stakeholder management } \\
\text { process (Olander and Landin, 2008) } \\
\text { - Evaluation of sustainable aspects in real } \\
\text { estate management (Persson and } \\
\text { Olander, 2004) }\end{array}$ & $\begin{array}{l}\text { - Qualitative stakeholder analysis for their } \\
\text { best integration into a project } \\
\text { - Analysis of influence factors in stakeholder } \\
\text { management } \\
\text { - Identification of interest and power of } \\
\text { stakeholders in a construction project } \\
\text { - Decision making in stakeholder } \\
\text { management } \\
\text { - Assessment of stakeholder influence on a } \\
\text { project }\end{array}$ & $\begin{array}{l}\text { - Stakeholder-Issue-Map } \\
\text { acc. to Winch (2007) } \\
\text { - Vested Interest - Impact } \\
\text { Index (Vill) acc. to } \\
\text { Olander (2007) }\end{array}$ \\
\hline
\end{tabular}

- Evaluation of stakeholder influence in the implementation of construction projects (Olander, 2007)

- Stakeholder impact analysis in construction project management (Olander, 2007)

- Analysis of key stakeholders and the need for teaching modules \& action manuals for planners (BMVBS, 2008)

- An agent operationalization approach for context specific agent-based modelling (Knoeri et al., 2011a)

- Social network model of construction (Chinowsky et al., 2008)

- Identification and evaluation of stakeholder influences and their decision Power/Interest Matrix making in a construction project

- Identification of stakeholders and evaluation of their interactions

- Determination of the strength of their Networking matrix effect on sustainability in real estate management to adapt course contents

- Analysis and modelling of decision making an relations between stakeholders that influence demand of recycled construction materials

- Determination of efficient teams based on knowledge sharing

- Effective project management

Agent based modelling (ABM) based on Structural Agent Analysis (SAA)

SNA: integration of knowledge and interaction

- Analysis and grouping of projects

- Managing stakeholders of megaprojects - Analysis of challenges in stakeholder (predominantly construction projects) (Littau, 2015) management

- Analysis of stakeholder networks

- 5P : Process, Product, People, Planet, Profit - Analysis of Influence, interests and influence of stakeholders

- Stakeholder analysis regarding their positioning, influence and power in a project and their attitude towards sustainability

- Management of sustainability in construction works (Persson, 2009)

- External stakeholder analysis in construction project management (Olander, 2006)

- Analysis of the project and stakeholder environment

STURE Model

- Analysis of sustainability programs

- Analysis of different implementation possibilities of sustainability 


\subsection{Literature gaps and conclusive remarks on the literature review}

Concluding the literature review, the following issues can be stated:

(1) Considerable modelling and simulation of C\&D mass flows has been done in recent years to quantify and reduce C\&D landfilling and to increase recycling rates. Lacking regional C\&D waste generation and management studies is still major research gap, as literature mainly focuses on national studies or urban scale (see Table 1, Wu et al. 2014, Ding and Xiao 2014, Menegaki and Damigos 2018). In regional C\&D waste management modelling and optimization, only few models (Hiete et al. 2011, Serrand et al. 2013, Schiller et al. 2017a,b) are available (Deilmann et al. 2014) (see Table 1). These focus on the C\&D waste management network, the transport optimization (e.g. Barles 2009, 2014 based on freight statistics), the location planning, the capturing, separation, recycling and treatment techniques and standards that have to be fulfilled. But, they neglect often stakeholders and decision makers, their decision making and their RC material demand as well as policy measures and their impact yet. Also, the social, economic, political and technical factors influencing the mechanisms of stock accumulation and removal in urban areas are not fully considered yet (Augiseau and Barles (2017), p. 163). First works can be found in Fishman et al. (2015).

Up to 36 main factors influence the generation and efficient management of C\&D waste (Menegaki and Damigos 2018). However, a quantitative study is lacking and (according to Menegaki and Damigos 2018, p. 13) main influencing factors in C\&D waste generation and management are still unclear and might vary regionally. As well, there is ambiguity in literature about the most effective barriers: regulatory and incentive environment, lack of wasteprocessing facilities, poor communication among involved parties, poor awareness and behaviour of project stakeholders, lack of awareness of environmental implications of waste disposal, cultural resistance and poor project processes (Menegaki and Damigos 2018, p.13; Park and Tucker 2017, p.228; Ajayi and Oyedele 2017, p. 57). Also, Schiller et al. 2017a see the need for integrating additional input variables to investigate the "enormous range of analytical 
possibilities that can be applied over the entire material loop". Also, they name the development of scenarios as "an interesting field" to reveal the socio-technical conservation potential and to draw up circular economy policies (Schiller et al. 2017a, p. 129).

(2) Furthermore, only few (5 out of 57 reviewed) studies considered civil works and infrastructures (Wu et al. 2014). Material considerations on networks, civil and underground works are neglected, e.g. because of lacking data or remote sensing (Augieseau and Barles 2017, p.161, Deilmann et al 2014). However, singular works exist e.g. for roads (Knappe et al. 2015).

(3) For NRBs stock data (number, its usage area and volume) only hybrid approaches are used (Naber et al. (2017)) based on the public and industrial gross building assets, new construction cost and statistics. Further data, material categories and projections on regional or district level or differentiated into structural and civil engineering is not available yet. Gaps in NRBs data were reduced in recent years (Schebek et al. 2017, Ortlepp et al. 2015a,b, Kleemann et al. 2014, Gruhler and Böhm 2011b, Schiller et al. 2010), but still are an issue.

(4) Main works in the field still depend on building types and building representatives only. GIS based approaches are only available on urban scale (Naber et al. 2017, Kleemann et al. 2016, Mastrucci et al. 2017).

(5) No or only few coverage of retrofits and (average) life time data (except for Deilmann et al. 2014) as well as no analysis or validation of model parameters prevail, either by case studies or linkages of top-down \& bottom-up model results (Augieseau and Barles 2017, p.161-163). Single works like Schiller et al. (2015) link top-down and bottom-up approaches, but still mention considerable data gaps.

(6) Stakeholders, policies and their impact on C\&D material flows are only very sparsely analysed in literature. One study investigated the stakeholder's influence on material decisions, when the decisions are made and by whom they are influenced (Knoeri et al. 2011). And, only two studies were found that combine building stock and material flow modelling with stakeholder perspectives (Ajayi and Oyedele 2017) or impacts of policy measures (Lu and Tam 2013). 
In this paper, we focus on (1) regional modelling, on (2) integration of infrastructure and (5) retrofitting activities and most important on (6) the impact of stakeholder objectives on resource conservation, the impact of different policies and the mutual interaction between stakeholders and policies.

Figure 1 visualizes the cited and reviewed literature in this paper via the counting of the key words of these papers and the references. The higher the counting of equal key words, the larger the bubbles. The figure also shows the respective references between the papers with connection lines and indicates the most frequent publication dates of the key words by its color.

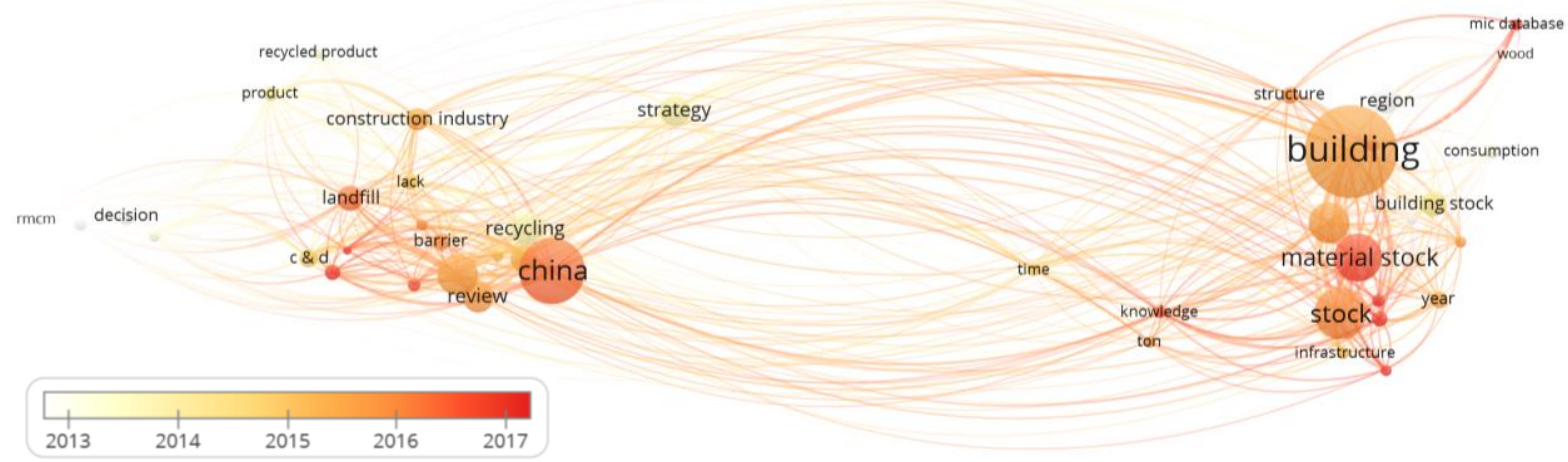

Figure 1: Network analysis (bottom) of title and abstract or international journal publications in English from reference list (except publications regarding balanced score card), visualized with VoSviewer (38 items; 2 clusters; minimum total count: 5; 364 links)

\section{Research approach}

In a first step, a desk-based research with key words based on the snowball system was performed to identify models and data on occurring and future material streams on a detailed district level. In this step, existing transferable models and data are analysed for their applicability and transferability (section 2). Using these results, we consolidated specific material characteristic values per building type and construction period (Figure 2) and modelled the regional building and infrastructure stock as well as its input and output material flows. Regarding RBs, existing census-based approaches are modified and used (sections 2.1, 4.2.1). Regarding NRBs, existing approaches are not suitable and a new hybrid method of approximating the stock and flows is developed (section 4.2.1). Regarding the road infrastructure, existing data and study results from Knappe et al. 2015 are used (section 4.2.2, 5.2). Data gaps especially for older buildings are filled with regression approaches per material, building type and construction periods. 


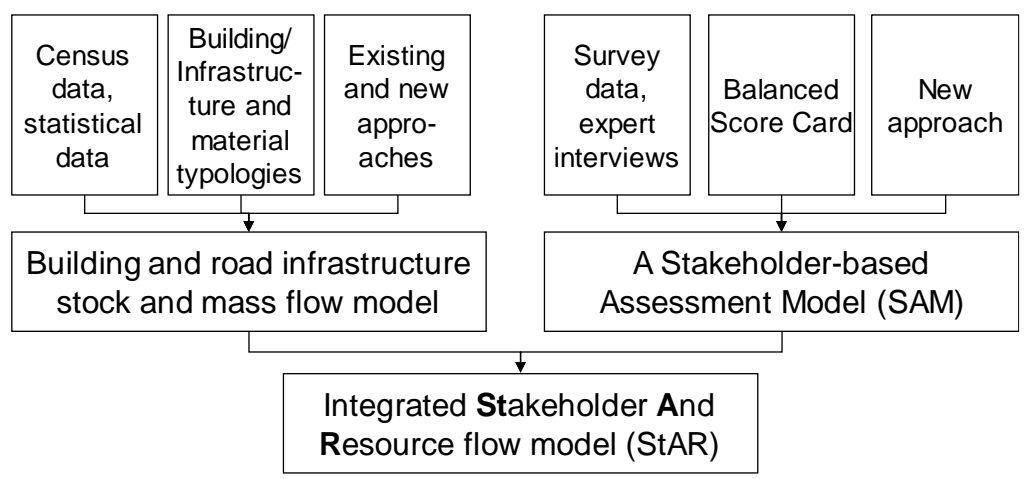

Figure 2: Research approach

In a second step, we analysed the stakeholder perspective with a desk-based research on stakeholder types and (political) measures for increase of resource efficiency and reduction of environmental impact. Also, we performed a survey to model stakeholder interaction, stakeholder willingness to act, stakeholder influence/power to change and the temporal course of measure effects. For the stakeholder assessment in the case study region, we developed and conducted two stakeholder surveys, evaluated the results and used the result in the newly developed stakeholder model.

In a last step, the material stock and flow submodel (section 4.2) is combined with the stakeholder submodel (section 4.3). The model results are analysed with different scenarios and sensitivity studies to understand model parameter influences. And, the results are compared with existing data and research, if possible. Model result is the output per input relation and balance of materials in buildings and infrastructures to detect future recycling and resource saving potentials as well as the stakeholder influence and impact.

In contrast to existing building stock and C\&D MFA approaches on county level (e.g. Schiller et al. 2017a,b), we combined a spatially localised MFA model for residential and non-residential buildings with road infrastructure on county level (as recommended e.g. by Schiller et al. 2017b, p. 684). And, we further combined this MFA model with policy measures and stakeholder perspectives (objectives, goal conflicts, mutual influence). Main contribution of this study to existing approaches is the investigation and impact analysis of proposed policy measures for resource conservation in the C\&D sector, the stakeholder perspective as well as the combination of both with conventional MFA modelling. 


\section{Integrated stakeholder and resource flow model (StAR model)}

\subsection{Model structure and main parameters}

Aim of the StAR model is to identify those measures or bundle of measures with the highest potential to reduce the annual mass flow balances and thus save primary resources on district and regional level. The model is structured into two main parts (see Figure 3, blue and orange): the building and infrastructure stock and flow model (section 4.2) and the stakeholder model (section 4.3). Both submodels are merged by an interface, where material stocks and flows are adjusted by the stakeholder decisions (section 4.4, Eq. (5)).

The model calculates the annual material input into and output from building and road infrastructure stock $^{15}$ per district and year as well as the net mass balance of material flows and the output per input relation of material flows. This balance increases or decreases due to building and infrastructure developments or resource efficiency or saving measures. An increase ${ }^{16}$ of the material flow balance in comparison to the previous year indicates the usage of additional primary materials (e.g. higher input and constant output). A decrease of the annual balance indicates resource savings by less primary input materials or higher use of secondary (recycling) materials from outputs, e.g. by prolongation of building product life cycles, decrease of population or higher recycling rates.

The model is implemented in Microsoft Excel and easily usable. All main model input parameters (see Table 4) of material flows, stakeholders and measures can be modified or extended in a user interface. It allows the free selection of bundles of measures (up to three simultaneously) with different application periods of the measures. Then, the model simulates the development of future material flows and balances per district and material category and for selected resource saving measures in

\footnotetext{
${ }^{15}$ For buildings, all values are calculated in gross volume $\left[\mathrm{m}^{3}\right]$ and in mass [kg]. For road infrastructures, mass values [kg] have been used per material due to the available data (based on Knappe et al. 2015) (see section 5.2).

${ }^{16}$ Theoretically, an increase of the balance could be induced by less input material and higher outputs. Then, more recycling material would be used and the stagnating of increasing population would be satisfied with less buildings and infrastructure. According to the published projections of future development in Germany, this case is highly improbable. It might only be the case in few shrinking districts or counties.
} 
several scenarios (see section 5.3). Results are shown and interpreted for a case study in the German

federal state Baden-Württemberg (section 5).

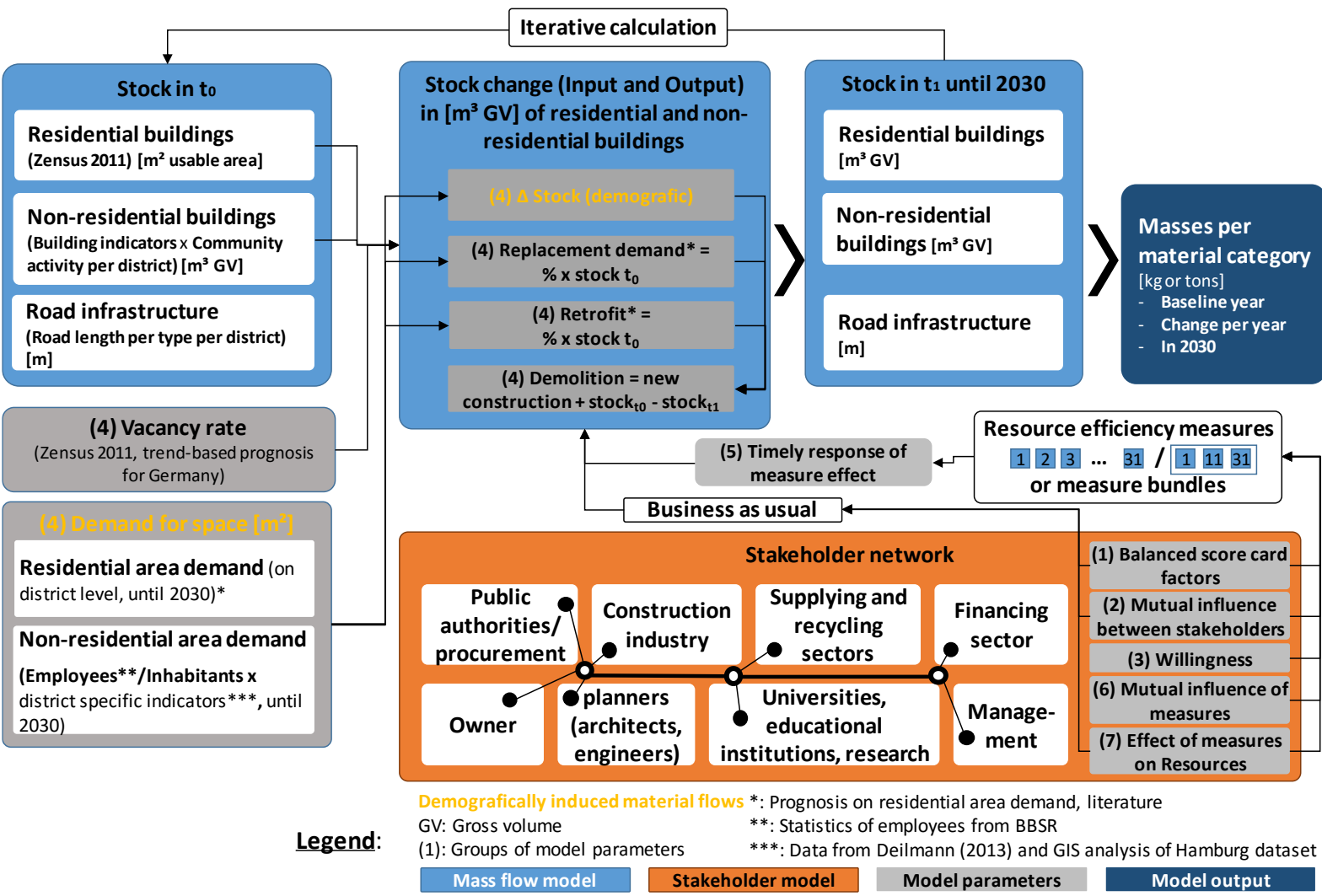

Figure 3: Model structure with material flow model (blue), stakeholder model (orange), model parameters (grey) and model output (dark blue) (own illustration)

Table 4: Main model input parameters

\begin{tabular}{|l|l|}
\hline No. & Main model input parameters \\
\hline$(1)$ & $\begin{array}{l}\text { Stakeholder characteristics (objectives, balanced score card factors, stakeholder influence on } \\
\text { resource conservation) }\end{array}$ \\
\hline$(2)$ & Stakeholder interrelationships (influence) \\
\hline$(3)$ & $\begin{array}{l}\text { Effects of measures on stakeholders (willingness of stakeholders to act according the measure, } \\
\text { impact of measure on stakeholders) }\end{array}$ \\
\hline$(4)$ & $\begin{array}{l}\text { Material flows related to political and societal framework conditions and development (vacancy rate, } \\
\text { the share of replacement demand (demolition and new construction on the same site), and the } \\
\text { retrofit rate and its temporal development and in the districts) }\end{array}$ \\
\hline$(5)$ & Temporal effect of measures \\
\hline$(6)$ & Interdependencies of measures (synergies or mutual weakening) \\
\hline$(7)$ & Effects of measures on material-specific and material-unspecific material flows (size of the effect) \\
\hline
\end{tabular}

\subsection{Building and infrastructure stock and flow sub model}

The main structure of the building and infrastructure model distinguishes between residential buildings (RBs) (single, double and multi-family houses), non-residential buildings (NRBs) (institutional 
buildings, office and administration buildings, agricultural buildings, non-agricultural buildings ${ }^{17}$, other) and road infrastructures (motorways, federal, state, district and local roads). Each category is further detailed in the following sections.

\subsubsection{Residential and non-residential buildings}

The modelling of the residential building stock was done similar to the approach of Schiller et al. $(2017 a, b)$ based on a bottom-up approach with construction periods, material composition indicators, and population development statistics. In the following, construction periods of the German Mikrozensus (2010) dataset were used for RBs (Table 5). Because of missing data, we assume that NRB and larger multifamily RB have a similar age structure. For NRBs, we used the distribution of construction periods of multi-family houses as an approximation to their age structure (number of buildings per construction period).

For each building type and construction period, a stock quantification and projection of the gross volume and on the material categories was done on district level (see also section 5.2 for the case study). The developed sub model on the building stock is based on synthetic reference buildings that represent typical volumes and materials of considered building types and construction periods ${ }^{18}$.

Table 5: Construction periods used in the model (Mikrozensus (2010))

\begin{tabular}{|l|}
\hline Construction periods \\
\hline before 1919 \\
\hline $1919-1948$ \\
\hline $1949-1978$ \\
\hline $1979-1986$ \\
\hline $1987-1990$ \\
\hline $1991-1995$ \\
\hline $1996-2000$ \\
\hline $2001-2004$ \\
\hline $2005-2008$ \\
\hline 2009 and later \\
\hline
\end{tabular}

In RBs, the number of buildings per RB type (single, double or multifamily) or respectively number of residential units, the average size of the buildings and residential units (based on census data) is

\footnotetext{
${ }^{17}$ Further detailed into production/workshop buildings, trade and storage buildings, hotels and restaurants (since 2002 in official statistics).

${ }^{18}$ Due to lacking data in this field, the best available references were used (see section 5.2). If better building stock data is available, e.g. for a specific building type, construction period or region, this might be easily updated in the database.
} 
multiplied with building-type specific material composition indicators $\left[\mathrm{kg} / \mathrm{m}^{3}\right.$ gross volume]. These material composition indicators per material mat result from previous work taken from literature, shown in section 5.2. Based on Zensus 2011 data $^{19}$, the projected RB stock as well as its input and output [ $\mathrm{m}^{3}$ and $\mathrm{kg}$ per material category] is calculated by the model starting from 2016.

The share of non-residentially used areas in RBs was analysed based on GIS data of an urban area and on Schlomann et al. 2015. The GIS based analysis found a higher gross volume of RB as expected from Zensus data (111\%). We assume that the difference results from commercial use in RB (see section 6.3 for a critical discussion on this assumption). Then, we put this surplus gross volume in relation to the gross volume of NRB to receive a share of commercial use gross volume in RB in urban areas. For our data in Hamburg, we calculated a share of $9.8 \%$. This share is added to all other RB gross volumes based on Zensus data in urban areas of the case study. Schlomann et al. 2015 estimate the share of commercial use (divided in commerce, trade, services) in different building types in Germany based on a survey to be $18 \%$ of the NRB gross volume in RB for Germany. This value is assumed for the rural ${ }^{20}$ districts in the case study. The distribution of the surplus share of commercial gross volume on the different types of residential buildings is based on the proportions of living space in the existing stock. Current NRB stock studies are based on the nationally available data. Regional data on the NRB stock are not available. To estimate the regional NRB material stock, a new hybrid method was developed. For this, official employee statistics per industry sector (with social insurance) and other available regional statistics ${ }^{21}$ were assigned to respective NRB building types. This was multiplied with the average usage area per employee and industry to derive NRB stock. From this, stock, demand and material flows were derived. For this purpose, the district-specific NRB stock was determined by derived indicators using available regional data from buildings, employment and other statistics for

\footnotetext{
${ }^{19}$ The Zensus 2011 is extrapolated by the authors until 2015.

${ }^{20}$ Landkreise Heilbronn, Hohenlohekreis, Schwäbisch Hall, Main-Tauber-Kreis, Heidenheim, Ostalbkreis, Neckar-OdenwaldKreis, Calw, Enzkreis, Freudenstadt, Breisgau-Hochschwarzwald, Emmendingen, Ortenaukreis, Rottweil, SchwarzwaldBaar-Kreis, Tuttlingen, Konstanz, Lörrach, Waldshut, Reutlingen, Tübingen, Zollernalbkreis, Alb-Donau-Kreis, Biberach, Bodenseekreis, Ravensburg, Sigmaringen

${ }^{21}$ Regional BW job statistics, general population statistics, school and kindergarden statistics, construction statistics, the Zensus 2011 database. As this is official statistical data, we expect a very low uncertainty in these datasets.
} 
Germany and Hamburg ${ }^{22}$. The indicators constitute of e.g. ratio of national NRB areas and the assigned employees subject to social insurance contributions (also used by Deilmann et al. 2013), $\mathrm{m}^{2}$ gross area of schools per school children or $\mathrm{m}^{2}$ gross area of office buildings per employee in service sectors.

Due to uncertainties in the data of Deilmann et al. 2013 and missing indicators for urban districts, we used the freely available 3D GIS city models and of Hamburg and Berlin and derived the gross volumes per NRB type and NRB-specific indicators based on regional statistics for both cities and the data of (Deilmann et al 2013). In the Hamburg GIS data, the respective average building height and building types according to ALKIS are available to calculate the footprint (base area) of NRB types and the regional indicators. In the Berlin GIS data, partly only the maximum building height was available so that the gross volume of the buildings was overestimated and not further used. The Hamburg data are not available for another German city or county for verification.

To calculate the indicators from the Hamburg data set, the ALKIS NRB types had to be assigned to the NRB typology of Deilmann et al. 2013. With the job statistics of Hamburg according to the different industry sectors, the gross volumes of the NRB stock and building-specific conversion factors from gross to net effective area per floor (from Deilmann et al. 2013), we calculated the effective area per employees and NRB type.

In some NRB types, the indicators calculated for Hamburg differ considerably from national values based on Deilmann et al. 2013. Due to uncertainties in storage and trading buildings in Deilmann et al. 2013 (see section 6.1), we use data from Hamburg for this NRB type. For NRB for restaurants and cultural use we differentiate between urban and rural districts in the same way. Furthermore, there are considerable differences in other NRB types with very low or non-existent relation to number of employees, such as buildings for agriculture and forestry, transport/ infrastructure development (car parks) or sports facilities. For agriculture and forestry buildings, we determined an indicator related to the agricultural land instead of employees and differentiated as above urban and rural indicators. NRB for transport/ infrastructure development and for sports were related to general population statistics.

\footnotetext{
${ }^{22}$ https://www.hamburg.de/bsw/geodaten/ (last access: 05 March 2019).
} 
The first is differentiated as above between urban and rural indicators based on Hamburg data or Deilmann respectively, while the latter use national values from (Deilmann et al. 2013). For educational buildings, we related the indicator to the number of children or students and not to the number of employees. Buildings for research were added to this in relation to number of employees in R\&D and the indicators for office areas. Hong et al. 2016, Schiller et al. 2015 and Fishman et al 2015 found a relation of material stock accumulation, economic growth (specifically of the tertiary sector) and population development (urbanization rate and area per capita). Thus, we modelled the NRB stock development respectively based on the expected future population and employee development.

The vacancy rate is approximated by the values for multifamily houses for 2011 (Zensus 2011). This is a simplification due to missing data. It is assumed that the multifamily RBs come closer to NRB than single-family houses. And, the development of the NRBs in a district is somehow linked to the RBs by housing the employees working in NRBs.

Retrofit rates are used from literature. According to (Deilmann et al. 2014, p.18, 31) retrofit rates of $2.5 \%$ can be assumed for RBs, which resemble a renovation every 40 years when a new generation takes over the buildings. The same source states that NRBs have an average life time of 30 years after which they are rather replaced instead of retrofitted (Deilmann et al. 2014, p. 26,31), hence resulting in a retrofit rate of only $0.5 \%$ for NRBs (e.g. for production/workshop, trade and storage, agricultural use) and $2.0 \%$ for NRBs that are similar to RB (e.g. Institutional buildings, office and administrative buildings, schools, hotels). The simulated retrofits are equally distributed over the shares of building types per construction periods. For replacements, we set a fixed ratio per building type and construction period. Also, we considered different non-residential usage shares within NRB, such as office areas in production buildings. 
Table 6: List of considered C\&D waste fractions in the model (similarly detailed than in existing literature of Schebek et al. $2017^{23}$, Schiller et al. $2015^{24}$, Buchert et al. 2004²5)

\begin{tabular}{|c|c|}
\hline Material group & Material \\
\hline \multirow{9}{*}{ Mineral waste fractions } & Concrete \\
\hline & Masonry $\left(>2000 \mathrm{~kg} / \mathrm{m}^{3}\right)$ \\
\hline & Light construction materials $\left(<2000 \mathrm{~kg} / \mathrm{m}^{3}\right)$ \\
\hline & Roof tiles (except for concrete) \\
\hline & Gypsum \\
\hline & Unbound materials (esp. from road construction) \\
\hline & Glass \\
\hline & Asphalt \\
\hline & Others (Screed, Plaster, Ceramics, Clay etc.) \\
\hline \multirow{2}{*}{ Metals } & Iron, Ferrous metals \\
\hline & Non-ferrous metals \\
\hline \multirow{5}{*}{ Organic waste fractions } & Timber (classes I+II, untreated) \\
\hline & Timber (classes III+IV, treated) \\
\hline & Plastics - PVC, EPS, PE, Others \\
\hline & Textils \\
\hline & Insulation materials \\
\hline
\end{tabular}

To determine the material composition indicators, we used different approaches: reference buildings from literature (Seemann 2003; Rentz et al. 1998a, b, c, d; Rentz et al. 1999), synthetical buildings (Ortlepp et al. 2017; IÖR 2018) and construction statistics for Baden-Württemberg (see section 5.2). For NRB, material composition indicators could be determined for construction periods since 1979. For $\mathrm{RB}$, they could be determined for construction periods since 1949. As for some building types and construction periods (especially before 1919, between 1919 and 1948 and between 1949 and 1978 ) ${ }^{26}$ no specific material composition values were available, we used different regression models based on the official construction statistics, synthetic building data (IÖR 2018) and single buildings (Rentz et al. (1998a,b,c,d), Rentz et al. (1999), Seemann (2003)) to approximate the missing values of specific building types, construction materials and construction periods between 1900 and 1979 (see Figure 4). To generate material composition indicators for RB, the average of the potency function value and

\footnotetext{
${ }^{23}$ FE-metals, copper, aluminium, concrete, masonry, brick and tiles, wood, glass, others

${ }^{24}$ Mineral materials (natural stone, aggregate/sand/rock flour/ashes, cement, lime/chalk, gypsum, clay/ceramics/brick, glass, insulation materials, fibres); compounds with fibres (mineral or plastic matrix); organic materials (plastics, timber, bitumen); metals (steel, aluminium, copper/zinc) (Schiller et al. (2015), p. 24).

${ }^{25}$ Mineral materials, timber, metals, plastics and others; with further differentiation within the categories.

${ }^{26}$ As of 2009, in the statistics on construction activity, the building material "other masonry" was replaced by "limestone sandstone", "aerated concrete" and "lightweight concrete pumice". For the regression, the material properties of the building materials lime sandstone", "aerated concrete" and "lightweight concrete pumice" were summed up. For the nonagricultural buildings, the material characteristics of the factory and workshop buildings, warehouses and warehouses and hotels and restaurants from the years 2001 to 2015 were summed up, so that the building type "non-agricultural buildings" is unified. The material characteristics of the building types single-family house and two-family house for the years 2002 to 2015 were also added so that they are comparable with the material characteristics from the years 1980 to 2001 . Thus, the continuity of the data was ensured for the regression.
} 
the exponential regression function value (average value of both dotted lines) was calculated for existing values (continuous line) and chosen to approximate the missing earlier construction periods. For NRB, the average of the potency function and logarithm regression function were used. A slight mismatch for values around the year 2016 seem to be reasonable. For the main materials, three experts (two researchers with $>20$ years of experience and one architect with $>15$ years of experience in the field) were interrogated for the plausibility of the regression values. As there is only limited data available (continuous lines) for the years 1976-2016, we suggest to support the data and regression validation with further data on material composition indicators of buildings from earlier construction periods in future research.

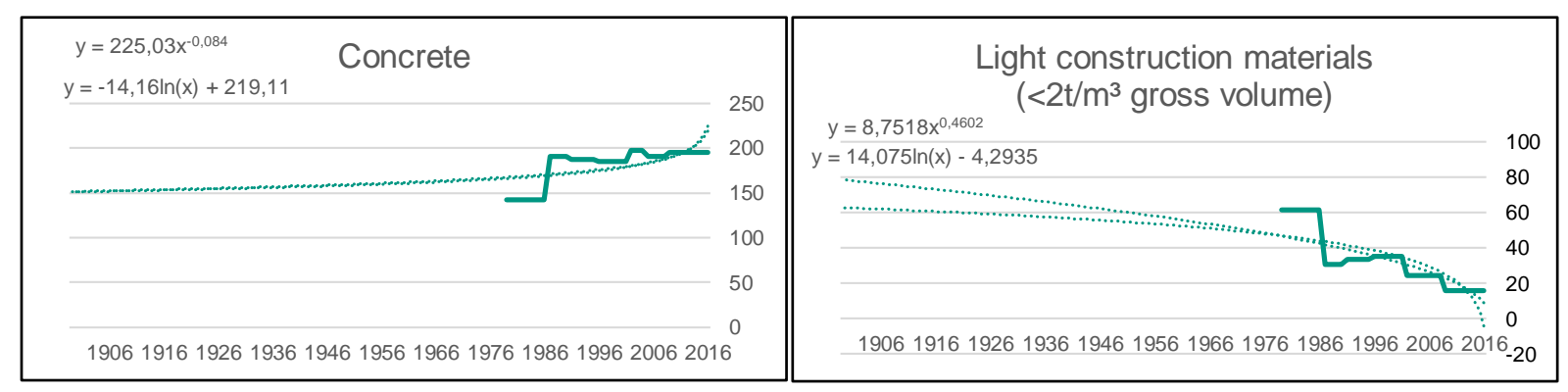

Figure 4: Exemplary regression for office and administration buildings $\left[\mathrm{kg} / \mathrm{m}^{3}\right.$ gross value of the building] for concrete and masonry (light construction materials $<2 \mathrm{t} / \mathrm{m}^{3}$ ) (continuous line: existing values based on own research; dotted line: approximated regression values)

\subsubsection{Road infrastructure}

Road infrastructure data for material stocks, flows and projections is based on previous works by Knappe et al. 2015. There, they combine and analyse a road infrastructure database (sib database) on district and city level with GIS data (ATKIS data from March 2014) in ArcGIS. This data includes road information (road axes, main road network, lane width, number of lanes, lane separation, hard shoulders), structures (areas of bridges/tunnels) and administrative assignments (to districts, inner/outer city location and construction authorities). From this, the road lengths and widths per road type and district were calculated and aggregated and assigned to the respective construction authority. The material masses of roads were derived with information on the vertical surface layer structures of the roads per road type (incl. especially asphalt, concrete or paving stones) (see also section 5.2). 
The road infrastructure stock and development was modelled according to the national study's reference scenario (Knappe et al. 2015), with the main parameters of settlement area development, target figures on federal roads, recycling of asphalt, concrete/ paving, unbound materials and the renovation cycles (see Table 10 and section 4.4 for scenario parameters). Based on available regional data (see section 5.2), for each district, specific lengths of the roads per road type are calculated and the road constructions are distributed based on the size of road works in the districts in relation to the whole region. Details are described in section 5.2.

\subsection{Stakeholders and policy measures sub model}

\subsubsection{Stakeholder identification and network}

In the C\&D industry, we identified the main stakeholders: planners (architects, engineers), financiers (owners, clients, banks, awarding authorities), management, suppliers of machinery, producers and suppliers of construction materials, construction industry itself, associations, educational \& research institutions and public authorities (Bosch and Rehfeld, 2003). To keep a stakeholder model manageable, we focused on four key stakeholder groups: (1) Public authorities, (2) Clients and owners, (3) Planners and construction companies and (4) Recycling, demolition and disposal companies and construction material manufacturers.

Public authorities (1) are one of the most powerful stakeholder group (Jin et al. 2017, p. 95f., Knappe et al. 2012, p. 54ff.), because of their influence in the market due to high awarding volumes and via legislation, although public authorities are not directly involved in most construction projects. Very influential and directly involved are clients and building owners (2) by their formative decisions and selection of planners, (sub)contractors and construction materials/products. The group of planners and construction companies (3) is a simplification that can often be found in reality in form of general contractors. They have a major influence on owners due to expertise and construction design (Knoeri et al. 2011). C\&D companies (4) are also grouped to a stakeholder group with high potential for 
resource conservation potentials (RESPOT) in supplier-producer relationships and their production processes.

In two surveys (see section 5.2 for details), we identified main influences and interest conflicts between these stakeholder groups, e.g. regarding unclear responsibility for C\&D waste. For all four stakeholder groups, we modelled the organizations' success as respective objective functions with weighted factors of the balanced scorecard according to Kaplan und Norton (1992). This includes also non-monetary goals, suitable key performance indicators and controlling of the achievement of objectives (Diederichs 2012; Figge et al. 2002). We used the five factors of environmental perspective, financial perspective, customer perspective, staff and development perspective as well as process perspective (see Table 7).

Table 7: Balanced scorecard categories

\begin{tabular}{|c|c|c|c|c|}
\hline $\begin{array}{l}\text { Environmental } \\
\text { perspective }\end{array}$ & Financial perspective & Customer perspective & $\begin{array}{l}\text { Staff / development } \\
\text { perspective }\end{array}$ & Process perspective \\
\hline $\begin{array}{ll}- & \text { Common good } \\
- & \text { Environmentally } \\
& \text { friendly acting }\end{array}$ & $\begin{array}{ll}- & \text { Profitability } \\
- & \text { Cost }\end{array}$ & $\begin{array}{ll}- & \text { Performance } \\
\text { - } & \text { quality } \\
\text { Customer } \\
\text { satisfaction } \\
\text { - } & \text { Image } \\
- & \text { Customer } \\
& \text { relations }\end{array}$ & $\begin{array}{ll}- & \text { Education / } \\
& \text { Knowledge } \\
- & \text { Productivity } \\
- & \text { Technology }\end{array}$ & $\begin{array}{ll}- & \text { Innovation } \\
- & \text { Spezialisation } \\
- & \text { Processes } \\
- & \text { Efficiency } \\
- & \text { Technical } \\
\text { - } & \text { excellence } \\
\text { Differentiation of } \\
\text { competition } \\
\text { Interactions with } \\
\text { other } \\
\text { stakeholders }\end{array}$ \\
\hline
\end{tabular}

For the identified stakeholder groups, we developed a logic to determine the characteristics and relationships between the stakeholder groups and related them with the identified resource efficiency measures, to find most effective measures. This stakeholder analysis is based on desk-based research (see section 2), surveys and expert interviews (see section 5.2).

The resulting stakeholder network modelling is described in section 4.3.2. In Figure 5, the circular economy for the C\&D sector is divided into three equally important areas of production, consumption and reduction economy with material flows in between the subsystems (symbolized by arcs) mostly within the system. Every area is subdivided into two levels: the building life cycle level and the stakeholder level with their effective influence during building life cycle stages. Primary materials are delivered to production and consumption and at the same time secondary materials and waste are 
recycled or disposed. At the end of the life cycle, buildings are "handed over" to companies of the recycling (reduction) sector and are disassembled and deconstructed into reuse, recycling or waste material flows. Then, respective stakeholders process and supply them to the production market or dispose them. Within the stakeholders, we map diverse relations between awarding authorities and planners both in production and reduction sectors, e.g. regarding the waste responsibility, acceptance or potential influence. Revenues of suppliers of secondary materials induce RC material demand, but lacking acceptance is represented by negative demand. By planning and deciding on demolition, stakeholders influence secondary material quality, homogeneity and degree of material purity and thus recycling options and revenues of recycling companies. Furthermore, recycling companies face high competition regarding input materials with disposal and filling companies and regarding output materials with gravel plants and primary material processing companies. Disposal and filling companies impact C\&D waste streams and $R C$ material in a negative way due to aggressive market prices. Despite the reduction of disposal capacities and the planned stricter legislation in Germany (Mantelverordnung), higher disposal mass flows are expected together with increasing transportation and cost. Also, stakeholder and material flow interaction between public authorities and associations is depicted in Figure 5. And, influences of stakeholders change during building life cycle and complexity of their interrelations increase with the project volume (Streck 2010, BBSR 2015b). 


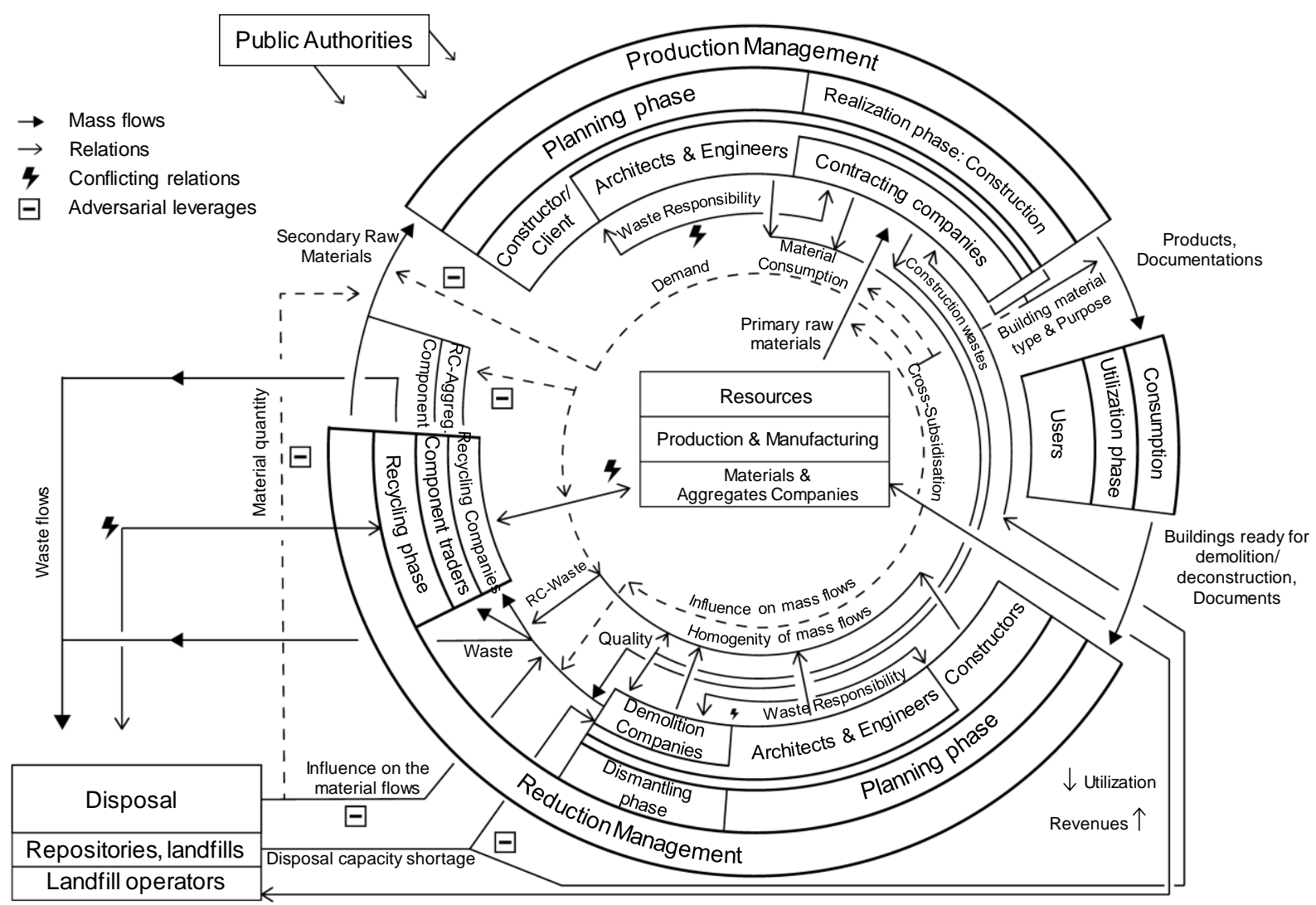

Figure 5: Circular economy framework and stakeholder network of construction sector (own illustration)

\subsubsection{Stakeholder objectives and measure modelling ${ }^{27}$}

For each stakeholder group $\mathrm{A}=\{\mathrm{a} 1 . . \mathrm{ai} . . \mathrm{aj} . . \mathrm{an}\}$, an objective function $Z_{a}$ quantifies their characteristics, their influence on resource conservation and their willingness to act according to possible circular economy measures $M=\left\{m_{1} \ldots m_{k}\right\}^{28}$ in the C\&D sector. The primary objective of stakeholders is profitability, but also ecological and technical factors. This is modelled by balanced scorecards according to Kaplan und Norton (1992) with five different weighting factors $g_{a, f a c t o r}$ for each stakeholder and category. The weighting factors are determined via the performed survey and interviews ( $\sum_{a} g_{a, \text { factor }}=1$ ) (see Müller et al. 2017, Eq. (3) and section 5.2 for survey details).

Relevant for the following model and analysis are primarily the external impacts such as environmental policies and measures on the respective objective functions of stakeholders. The impact $w_{m, a}$ of a measure $m \in M$ on stakeholder success of stakeholder $a \in A$ is thus quantified with factors in the

\footnotetext{
27 Part of this work was pre-published and discussed in Müller et al. (2017).

${ }^{28}$ The list of used measures in this paper can be found in the Appendix, Table 15.
} 
objective function of every stakeholder. To determine the total effect $w_{m . a}$ of a measure $m \in M$ on the stakeholder's $a \in A$ success, we define weighted ${ }^{29}$ balanced scorecard factors according to Müller et al. (2017, Eq. (4)):

$$
\begin{array}{r}
w_{m, a}=g_{\text {fin }_{a}} * w_{m, \text { fin }_{a}}+g_{\text {custom }_{a}} * w_{m, \text { custom }_{a}}+g_{\text {process }_{a}} * w_{m, \text { process }_{a}} \\
+g_{\text {develop }} * w_{m, \text { develop }}+g_{\text {environ }_{a}} * w_{m, \text { environ }}
\end{array}
$$

With the different measure intensities $s_{m, a}$ and also the degree to which a stakeholder is affected, we can define the preliminary readiness to act or acceptance of stakeholder $a \in A$ as $B_{m, a}=w_{m, a} * s_{m, a}$ (Müller et al. 2017, Eq. (5)). It is called preliminary acceptance as the stakeholder interaction is not considered yet. A negative $B_{m, a}$ indicates a negative attitude or resistance against a policy measure. Mutual influences $E_{i j}$ of stakeholders $a_{i}$ and $a_{j}$ (see Appendix Figure 17) are caused by neighbourhood effects, voluntary commitments and market adaption, image or competitiveness reasons. Including them leads to an isolated readiness to act or accept per stakeholder $B_{m, a}^{\prime}$ (each stakeholder optimizing its own objective) of measure $m$. The network character of the stakeholder model is considered by the mutual influence between stakeholders. The size of the influence $e_{a_{i} a_{j}}$ of stakeholder $a_{i}$ on stakeholder $a_{j}$ is additionally influencing the objective function value and decision of both stakeholders in question. This is described by Müller et al. (2017, Eq. (6)):

$$
E_{a_{i} a_{j}}(m)=w_{m, a} * s_{m, a} * e_{a_{i} a_{j}}
$$

$\boldsymbol{E}_{\boldsymbol{a}_{i} \boldsymbol{a}_{j}}(\boldsymbol{m})=$ Influence of stakeholder $a_{i}$ on stakeholder $a_{j}$ regarding policy measure $m$ [-50;50]

$\boldsymbol{e}_{a_{i} a_{j}}=$ Size of influence $e_{a_{i} a_{j}}$ of stakeholder $a_{i}$ on stakeholder $a_{j}[0 ; 5]$

The size of the relationships is determined by a pairwise comparison with AHP (according to Saaty 1990). With the influence of other stakeholders, we receive an extended, additional willingness to act (according to Müller et al. 2017, Eq. (7)):

$$
\text { Infl } l_{a}=\frac{\frac{1}{n} \sum_{i, j=1}^{n} E_{a_{i} a_{j}}(m)}{\frac{1}{n} \sum_{i, j=1}^{n} e_{a_{i} a_{j}}}
$$

Inf $\boldsymbol{l}_{\boldsymbol{a}}=$ Extended, additional willingness to act / acceptance of stakeholder a [-10;10]

$\boldsymbol{n}=$ number of involved stakeholders +

\footnotetext{
${ }^{29}$ The factors weights $g_{\text {factor }}$ are gathered with the surveys and interviews described in section 5.2.
} 
As the stakeholders are mainly motivated by the maximization of their respective objective value, we receive an extended willingness to act of $B_{m, a}^{\prime}$ with (according to Müller et al. 2017 (Eq. (8 and 7))):

$$
B_{m, a}^{\prime}=\frac{\operatorname{Infl} l_{a}+2 * w_{m, a} * s_{m, a}}{3}=\frac{\frac{\frac{1}{n} \sum_{i, j=1}^{n} E_{a_{i} a_{j}}(m)}{\frac{1}{n} \sum_{i, j=1}^{n} e_{a_{i} a_{j}}}+2 * w_{m, a} * s_{m, a}}{3}
$$

$\boldsymbol{s}_{\boldsymbol{m}, \boldsymbol{a}}=$ Intensity of influence of measure $m$ on stakeholder a [1;5]

$\boldsymbol{n}=$ Number of stakeholders

$\boldsymbol{E}_{\boldsymbol{a}_{i} \boldsymbol{a}_{j}}(\boldsymbol{m})=$ Influence of stakeholder $a_{i}$ on stakeholder $a_{j}$ regarding measure $m[-50 ; 50]$

$\boldsymbol{e}_{a_{i} a_{j}}=$ Size of influence $e_{a_{i} a_{j}}$ of stakeholder $a_{i}$ on stakeholder $a_{j}[0 ; 5]$

This means that the isolated willingness to act is influenced by the mutual, extended willingness to act (acceptance) of stakeholders $\operatorname{Infl}_{a}$ as well as by influence and by the size of measure $w_{m, a}$ and $s_{m, a}$. The stakeholder relations are based on the Vested Interest-Impact Index (ViII). The attitude of a stakeholder for or against resource conservation range between active enemy and active supporter [$1 ;-0.5 ; 0 ; 0.5 ; 1]$ and the stakeholder impact index per stakeholder follows Olander (2007) (also following Müller et al. 2017). However, Müller et al. 2017 did not include interdependencies between simultaneous measures as well as temporal and material-specific effects of measures.

A simultaneous implementation of multiple measures induces considerations on the additivity of resource conservation effects, as well as questions of positive reinforcement, neutralizing or mutual weakening and negative/unwanted effects (Lee 2013). Also, the different measure types imply different temporal effects, e.g. financial measures or legal regulations will effect resource conservation much faster than informational measures. However, the latter might have a more long-term effect or even an after-effect in contrast to the previous two.

Furthermore, we differentiate material-specific and material-unspecific measures (Table 15, Table 17), because of their differing effects on materials and resource savings.

\subsubsection{Simultaneous measures or measure bundles}

Parallel application of two or more resource-efficiency measures might affect their respective impact. In literature, only few approaches examine the coherent effect of several or all legal measures (Lee 
2013). To quantify the cooperation potential ${ }^{30}$ between two or three simultaneous measures or measure bundles, we used a second stakeholder survey for a quantification of this value on an ordinal scale (from $0=$ measures cancel each other out to $4=$ measures reinforce each other strongly). This approach is based on a symmetrical interaction analysis. For three measures, average values of the interdependence coefficients were used.

\subsubsection{Temporal effects of measure impact}

We differentiate short-term, medium-term and long-term effects of 31 measures in five categories (Appendix Table 15 and Figure 7): research \& development (R\&D), information, organisation, financial and legal measures with different time horizons and courses of impact (Table 8, Figure 6). For the modelling of policy measure impacts, in literature different time horizons are mentioned (see Table 8). We differentiate independent (variant $a$ ) and dependant (variant b) short-, medium- and long-term as well as aftereffects of a measure (Figure 6). The dependant variant is related to the total projection time frame. In our projection, we chose variant 3(b) (Figure 6) with a time horizon between 15-30 years (2016-2030) for this case study, because of the slow changes in the C\&D industry with respect to resource efficiency and conservation. In this case, the short-term perspective is relatively long with 10 years. Then, for every measure category, a generic and characteristic temporal course of measure impact was established based on literature (Figure 7), refined and validated by three experts (two researchers with $>20$ years of experience and one architect with $>15$ years of experience in the field).

Table 8: Time horizons of measures

\begin{tabular}{|l|l|l|l|}
\hline & Short-term & Medium-term & Long-term \\
\hline Wünsche (2015) & $<1$ year & $1-5$ years & $>5$ years \\
\hline Bölke (2003) & $1-5$ years & $6-10$ years & $11-20$ years \\
\hline Harlfinger (2006) & Bis 10 years & $10-30$ years & $>30$ years \\
\hline Our approach (variant a) & $1-5$ years & $6-10$ years & $>10$ years \\
\hline Our approach (variant b) & The rounded third of the total horizon respectively & Remaining time \\
\hline
\end{tabular}

\footnotetext{
${ }^{30}$ The cooperation potential of a measure $m_{1}$ is the relation of the interdependence coefficient to a measure $m_{x}$ to the average of all interdependence coefficients of all other measures. It shows how good measures $m_{1}$ and $m_{x}$ can be combined with respect to their resource conservation potential.
} 


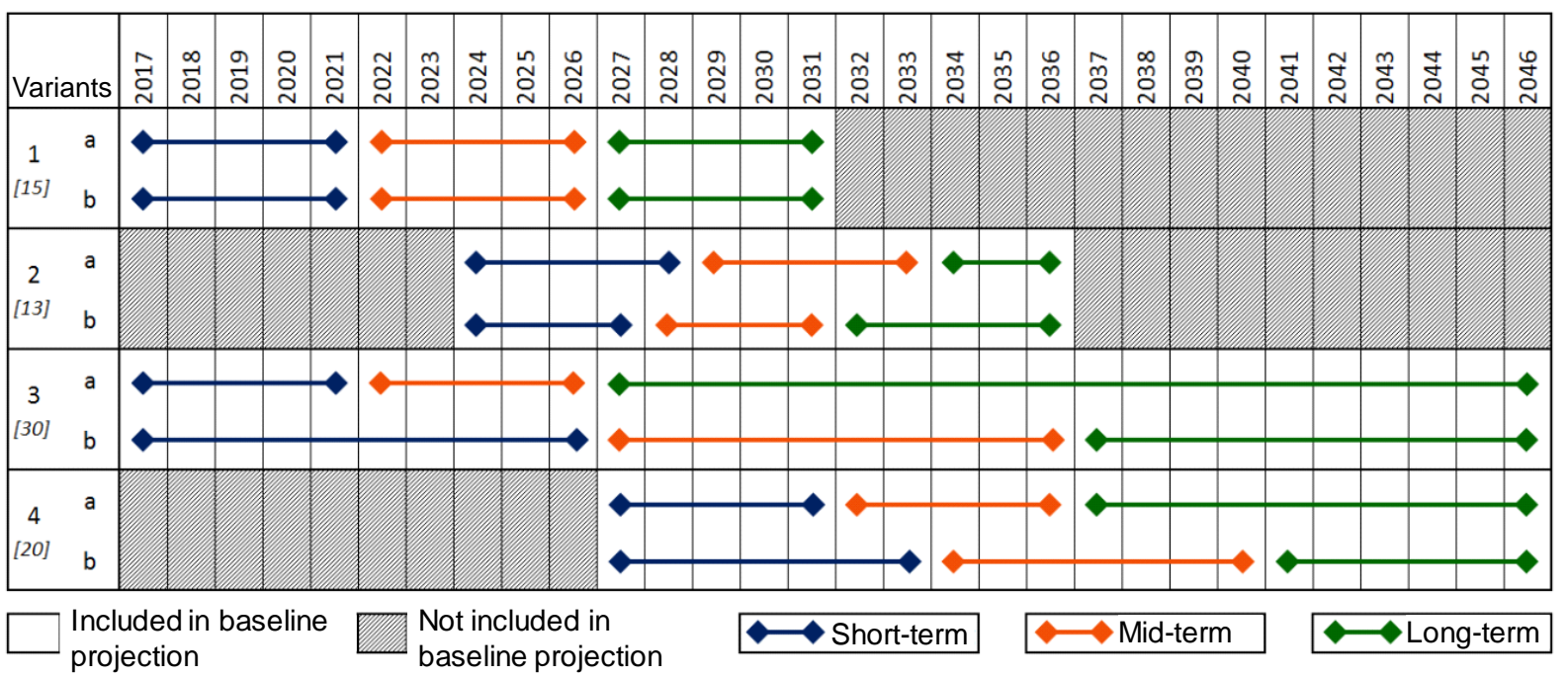

Figure 6: Splitting of periods and analysis of time horizons of measures and the different time course of their impact, white: included in baseline model calculations, grey: excluded in baseline model calculations

Figure 7 shows the assumed generic development of policy measures' effect per measure categories (e.g. financial measures or information measures). For example, it takes some time to communicate information measures and to act accordingly as acting is voluntary and processes have to be changed. In contrast, for financial measures like incentives or taxes we assume a faster adaption by stakeholders as well as a higher measure effect than by other measures. Financial measures like low-interest loans or funding for sustainable pilot projects are rather short-term without aftereffects on stakeholders' decision making (Busse 2012).

For information measures, we expect an aftereffect because of better education and training, while for financial measures this cannot be expected. Information measures might induce changes in behaviour, but rather develop over time (Busse 2012). Especially ecological information spread slowly/long-term (Sepp 1996). Structural organisational measures affect institutions/organisations directly. Their effects on resource-savings are expected short to medium-term.

R\&D measures and profound technical changes require 10-20 years for development and market penetration (Schmidt-Bleek and Klüting 1994). Thus, effects are long-term and have aftereffects beyond the horizon of the intervention.

Legal measures are immediately effective. 


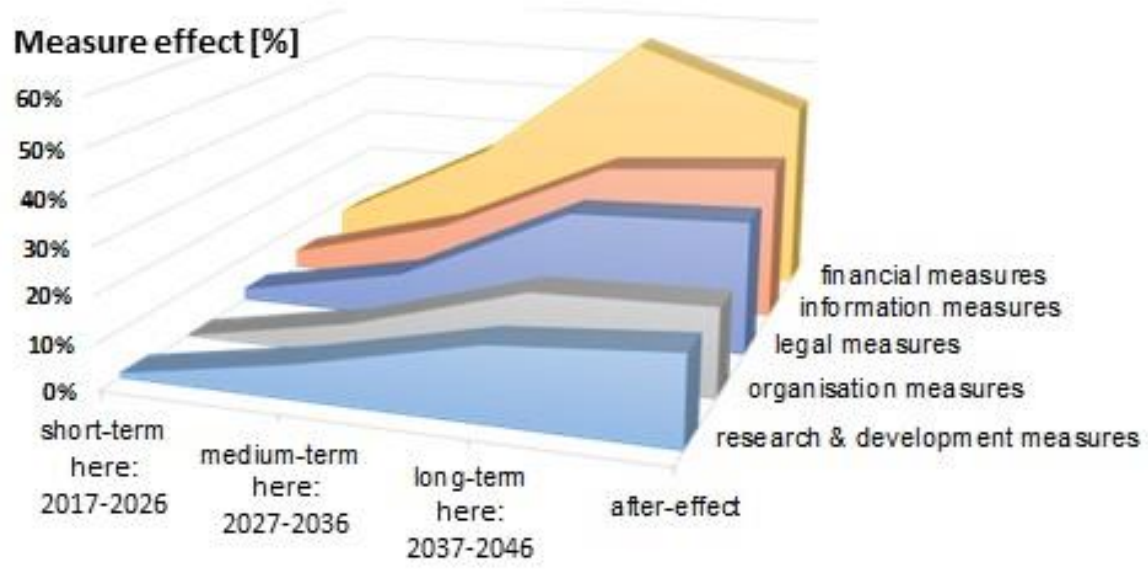

Figure 7: Generic temporal course of measure effect [\%] for each policy measure categories (on y-axis) over time (on $x$ axis)(own depiction based on Schmidt-Bleek and Klüting 1994, Busse 2012, Sepp 1996)

\section{Material-specific effects of measures}

Effects of measures are associated either with specific (impacts on particular metal, mineral or organic material flows) or unspecific (same impact on every category) material categories. The survey respondents were asked to evaluate for the reduction effect on primary material consumption qualitatively on a Likert's scale (very low, low, neutral, high, very high) all 31 measures. For example, an additional tax on specific primary raw materials would directly affect their price, demand and material flow. Survey respondents evaluated the effect of this tax to be higher on mineral material flows ( 3.08 of 5 points) than on metals ( 2.83 of 5 ) or organic material flows ( 2.67 of 5$)$. The generic versus specific effect of measures on materials and material groups allows a more purposeful resource management.

\subsection{Transformation of baseline material flows}

In the material flow model (see section 4.2), we calculate baseline material stocks and flows for the baseline year 2016 and for projections until 2030. Then, these are transformed by stakeholder and policy measure influences. To calculate the influence of resource conservation measures on material flows we use a transformation component that is defined as (for variable definitions see Appendix):

$$
\begin{aligned}
& S_{M_{d}, \text { ber }, \text { mat }, j}^{t}=S_{b e r, m a t, j}^{b} *\left(1-\delta_{M_{d}, \text { mat }, j}\right) \\
& \forall \text { ber } \in \text { BER, } \quad \forall \text { mat } \in \text { MAT, } \quad \forall j \in J_{t}
\end{aligned}
$$


$\boldsymbol{S}_{\boldsymbol{M}_{d}, \text { ber,mat }, j}^{t}=$ Transformed material flow by application of measure $M_{d}$ of materials mat in application area ber and year $j$

$\boldsymbol{\delta}_{\boldsymbol{M}_{\boldsymbol{d}}, \text { mat }, j}=$ Transformation factor, depending on $M_{d}$, materials mat and year $j$

The transformation factor $\boldsymbol{\delta}_{M_{d}, \text { mat,j }}$ is derived in the following subsections. Also, restrictions like input or output limits can be set, resulting in limited transformed material flows:

$$
S_{M_{d}, \text { ber }, \text { mat }, j}^{t}= \begin{cases}S_{\text {min }}(\text { mat }), & \text { if } S_{\text {ber, }, \text { mat }, j}^{b} *\left(1-\delta_{M_{d}, \text { mat }, j}\right) \\ S_{\text {max }}(\text { mat }), & \text { if } S_{\text {ber, }, \text { mat }, j} *\left(1-\delta_{M_{d}, \text { mat }, j}\right)>S_{\text {max }}(\text { mat }) \\ S_{\text {ber,mat }, j}^{b} *\left(1-\delta_{M_{d}, \text { mat }, j}\right), & \text { otherwise }\end{cases}
$$

$\boldsymbol{S}_{\boldsymbol{m i n}}(\boldsymbol{m a t})=$ annual minimum of a material balance per application area

$\boldsymbol{S}_{\boldsymbol{m i n}}(\boldsymbol{m a t})=$ annual maximum of a material balance per application area

\subsubsection{Effects of a policy measure on material flows}

For simulation of all measures $M_{d}$, for every $m \in M_{d}$ the effect on material flows is calculated separately per material mat according to:

$$
a_{m, \text { mat }}=s_{m, \text { mat }} * r_{m, \text { mat }}
$$

$\boldsymbol{a}_{\boldsymbol{m}, \boldsymbol{s}}=$ Effect of $m$ on mat $[-5 ; 5]$

$\boldsymbol{s}_{\boldsymbol{m}, \boldsymbol{m a t}}=$ Size of effect of $\mathrm{m}$ on mat $[1 ; 5]$

$\boldsymbol{r}_{\boldsymbol{m}, \boldsymbol{m a t}}=$ Effective direction of $m$ on mat $[-1 ; 1]$

Here, the effect size of a measure $s_{m, m a t}$ is multiplied with the effective direction of the measure $r_{m, m a t}$, on a material. The effective direction indicates whether a policy measure has a positive or negative influence on material conservation.

And, the stakeholder-related measure effectivity $E f f_{m}$ is calculated, including the effect of a measure on resource conservation $l_{m}$, the influence of stakeholder a on resource conservation $r_{a}$ and the willingness to act according a measure $B_{m, a}^{\prime}$. The factor $l_{m}$ describes the impact of policy measure $m$ on ecological, economic and social aspects (Müller et. al 2017). The effectivity is following the Vested Interest-Impact Index ViII (see also Müller et al. 2017, Eq. (9)), because the expected effectivity is defined by the relative effect size of a measure on resource conservation and the relative willingness to act:

$$
E f f_{m}=\frac{1}{|A|} \sum_{a \in A} \sqrt[3]{\frac{l_{m} * r_{a} * B_{m, a}^{\prime}}{250}}
$$


$\boldsymbol{E} \boldsymbol{f} \boldsymbol{f}_{\boldsymbol{m}}=$ stakeholder-based effectivity of a measure $m,[-1 ; 1]$

$\boldsymbol{l}_{\boldsymbol{m}}=$ Impact of measure $m$ on resource conservation, $[1 ; 5]$

$\boldsymbol{r}_{\boldsymbol{a}}=$ Influence of stakeholder a on resource conservation, [1;5]

$\boldsymbol{B}_{\boldsymbol{m}, \boldsymbol{a}}^{\prime}=$ willingness to act or accept measure $m$ of stakeholder $a,[-10 ; 10]$

As a joint effectivity is modelled, we use the average value over all stakeholders (Müller et. al 2017). The measure-specific effectivity $E f f(m)$ indicates which percentage of the maximum impact of the measure can be achieved on resource protection, taking into account stakeholders' influence and willingness to act or accept measure $m$. The maximum effect equals 1 (100\%).

\subsubsection{Timely course of effect of a measure}

The specific course of effect in the application period of a measure $\boldsymbol{e}_{\boldsymbol{m}, j}$ can be defined as:

$$
e_{m, j}= \begin{cases}e_{m}(1), & j \in\left[\text { start }_{m} ; \text { start }_{m}+\left\lceil\frac{\text { duration }}{3}\right\rceil-1\right] \\ e_{m}(2), & j \in\left[\text { start }_{m}+\left\lceil\frac{\text { duration }}{3}\right\rceil ; \text { start }_{m}+2 *\left\lceil\frac{\text { duration }}{3}\right\rceil-1\right] \\ e_{m}(3), & j \in\left[\text { start }_{m}+2 *\left\lceil\frac{\text { duration }}{3}\right\rceil ; \text { end }\right]\end{cases}
$$

$\boldsymbol{e}_{\boldsymbol{m}, j}=$ component of course of effect of $m$ during year $j, \boldsymbol{e}_{\boldsymbol{m}, j} \in[0 ; 1]$

$\boldsymbol{e}_{\boldsymbol{m}}(\mathbf{1})=$ short-term component $[0 ; 1]$

$\boldsymbol{e}_{\boldsymbol{m}}(\mathbf{2})=$ medium-term component $[0 ; 1]$

$\boldsymbol{e}_{\boldsymbol{m}}(\mathbf{3})=$ long-term component $[0 ; 1]$

With this modelling, we compile short-term, medium-term and long-term effects $e_{m}(1), e_{m}(2)$ and $e_{m}(3)$ to the specific timely course of the measure effect of each measure. In this model, we assume a rather generic temporal course of measure effect for each measure category (see Figure 7 for visualization). However, with more precise data these assumptions can be adjusted and specified to single measures.

To limit the measures' effect to their simulated application period, we define a decision variable $x_{m, j}$ whether a measure is performed in year $j$ or not:

$$
x_{m, j}= \begin{cases}1, & \text { if } m \in M_{d} \wedge j \geq \text { start }_{m} \\ 0, & \text { otherwise }\end{cases}
$$

$\boldsymbol{x}_{\boldsymbol{m}, j}=$ decision variable on application of measure $m$ in year $j, \boldsymbol{x}_{\boldsymbol{m}, j} \in[0 ; 1]$

Additionally to short-, medium- or long-term components in $\boldsymbol{e}_{\boldsymbol{m}, j}$, an aftereffect $n_{m, j}$ is considered in the years after the measure enforcement. For this, the time frame of the aftereffect is defined as: 


$$
y_{m, j}= \begin{cases}1, & \text { if } m \in M_{d} \wedge j \geq \text { end }_{m} \\ 0, & \text { otherwise }\end{cases}
$$

$\boldsymbol{y}_{\boldsymbol{m}, j}=$ decision variable on ended application of measure $m$ in year $j, \boldsymbol{y}_{\boldsymbol{m}, j} \in[0 ; 1]$

To calculate both cases, „business-as-ususal“ case (without additional resource conservation measures) and different resource conservation cases with measures $p$ and $q$ and to distinguish between both, we define a decision variable:

$$
\begin{aligned}
& z_{m}= \begin{cases}1, & \text { if model results include stakeholder network } \\
0, & \text { otherwise }\end{cases} \\
& z_{m_{p}}=z_{m_{q}} \quad \forall m_{p}, m_{q} \in M_{d}
\end{aligned}
$$

Also, it has to be decided for a jointly considered combination of measures (set of up to three measures), whether the model should evaluate material effects only or with stakeholder influence (Eq. $(13))$

From the previous definitions, the transformation component ${ }^{31} \delta_{m, m a t, j}$ results with $\left(z_{m}=1\right)$ or without $\left(z_{m}=0\right)$ stakeholder consideration as:

$$
\delta_{m, m a t, j}= \begin{cases}\frac{E f f_{m} * a_{m, m a t} *\left[\left(e_{m, j} * x_{m, j}\right)+\left(n_{m} * e_{m, E n d e_{m}} * y_{m, j}\right)\right]}{5}, & z_{m}=1 \\ \frac{a_{m, m a t} *\left[\left(e_{m, j} * x_{m, j}\right)+\left(n_{m} * e_{m, E n d e} * y_{m, j}\right)\right]}{5}, & z_{m}=0\end{cases}
$$

$\boldsymbol{\delta}_{\boldsymbol{m}, \boldsymbol{m a t}, j}=$ Percental change of material flow of material mat in year $j$ by measure $m,[-1 ; 1]$

$\boldsymbol{n}_{\boldsymbol{m}, j}=$ Component of aftereffect of $m$ in year $j[0 ; 1]$

The transformation component $\delta_{m, m a t, j}$ thus includes the effectivity $E f f_{m}$ of policy measures on resource conservation, as well as the effect on material flows $a_{m, m a t}$ per material mat and the timely defined short-term, medium-term and long-term and after effects $e_{m}, x_{m, j}, y_{m, j}$ and $n_{m}$.

\subsubsection{Interdependences of multiple policy measures}

For a single measure $m\left(\left|M_{d}\right|=1, M_{d}=\{m\}\right)$, the transformation factor is

$$
\delta_{M_{d}, m a t, j}=\delta_{m, m a t, j} \quad \forall m a t \in M A T, \forall j \in J
$$

In the case of two simultaneous measures applied in the same year $\left(\left|M_{d}\right|=2 ; M_{d}:=\left\{m_{p}, m_{q}\right\}\right.$, $\left.m_{p}, m_{q} \in M ; z_{m_{p}}=z_{m_{q}}\right)$ the transformation factor is:

\footnotetext{
${ }^{31}$ The quotient of 5 is used for standardization.
} 


$$
\delta_{M_{d}, m a t, j}=\operatorname{dep}_{M_{d}} * \sum_{m \in M_{d}} \delta_{m, m a t, j}
$$

This considers the interdependency coefficients $d e p_{M_{d}}$ from the measure interaction matrix matrix $_{m_{p} m_{q}}$. The interaction matrix indicates the mutual influence of two or three simultaneously performed policy measures. The values of matrix $_{m_{p} m_{q}}$ were gathered in the performed survey. In the model, single, two and three parallel policy measures can be evaluated. For $\left|M_{d}\right|=2$, the transformation coefficient is defined as

$$
\operatorname{dep}_{M_{d}}= \begin{cases}\text { matrix }_{m_{p} m_{q}}, & j \geq \text { start }_{m_{p}} \wedge j \geq \operatorname{start}_{m_{q}} \\ 1, & \text { otherwise }\end{cases}
$$

$\boldsymbol{d e p}_{\boldsymbol{M}_{\boldsymbol{d}}}=$ Interdependence coefficient of measure bundle $M_{d},\left|M_{d}\right|=2,[-2 ; 2]$

matrix $_{\boldsymbol{m}_{p} \boldsymbol{m}_{q}}=$ Value in interaction matrix of measures $m_{p}$ and $m_{q},[-2 ; 2]$

For the maximum of three simultaneous measures $\left(\left|M_{d}\right|=3\right) ; M_{d}=\left\{m_{p}, m_{q}, m_{r}\right\}, m_{p}, m_{q}, m_{r} \in M$; $\left.z_{m_{p}}=z_{m_{q}}=z_{m_{r}}\right)$, we calculate the interdependence coefficients as follows:

$$
\operatorname{dep}_{M_{d}}=\left\{\begin{array}{c}
\frac{\text { matrix }_{m_{p} m_{q}}+\text { matrix }_{m_{p} m_{r}}+\text { matrix }_{m_{q} m_{r}}}{3}, \quad j \geq \operatorname{start}_{m} \forall m \in M_{d} \\
\operatorname{matrix}_{\alpha, \beta}, \quad\left(j \geq \operatorname{start}_{\alpha} \wedge j \geq \operatorname{start~}_{\beta} \wedge j<\text { start }_{\gamma}\right)^{*} \\
1, \quad \text { otherwise }^{*}
\end{array}\right.
$$

$* \forall \alpha, \beta, \gamma \in M_{d}$ mit $\alpha \neq \beta \neq \gamma$

We assume in the triple-measure case, that the cumulated interdependence is best approximated by the average of all three matrix values, as there is no information about this in literature. Then, depending on the number of selected policy measures to be evaluated, the transformation factor can be calculated according to (16) and we receive the influence of policy measures and stakeholders on material stocks and flows in the C\&D sector.

However, with increasing number of considered measures, uncertainties in the mutual influence values of the measures strongly increase and results are getting less plausible. Thus, we restricted the number of simultaneous policy measures that are evaluated by the model to a maximum of three. 


\subsubsection{Cooperation potential between policy measures}

As well as the calculation of the interaction matrix, which reflects the interdependencies of the measures among each other, the cooperation potential of a measure $m_{p} \in M \operatorname{MKOOP}\left(m_{p}\right)$ can be calculated with:

$$
\operatorname{MKOOP}\left(m_{p}\right)=\frac{\sum_{\substack{m_{q} \in M \\ m_{q} \neq m_{p}}} \text { matrix }_{m_{p} m_{q}}}{2 *(|M|-1)}
$$

$\operatorname{MKOOP}\left(m_{p}\right)=$ cooperation potential of measure $m_{p}[-1 ; 1]$

This reflects the average values of the interaction matrix matrix $_{m_{p} m_{q}}$ of the considered measure $m_{p}$ to the second or third simultaneously evaluated policy measure. The cooperation potential of measures $\operatorname{MKOOP}\left(m_{p}\right)$ is positive if measures will produce synergies or negative if mutual weakening of measures is expected. It can be used to decide on scenario construction and policy measure combination in simulations and implementation. The higher the value of $\operatorname{MKOOP}\left(m_{p}\right)$ the more promising is the combination of the two or three policy measures as they mutually reinforce each other.

\subsubsection{Simultaneous comparison of all policy measures}

To compare all 31 policy measures simultaneously, we consider isolated measure application in the total projected time frame $J_{t}\left(M_{d}=\{m\},\left|M_{d}\right|=1\right.$ and $\left.J_{m}=J_{t}=J\right)$ with start $_{m}=$ start $_{t}=$ start and $e n d_{m}=e n d_{t}=e n d$, as well as $x_{m, j}=1, \forall j \in J$ and $y_{m, j}=0, \forall j \in J$. Due to a comparable simulation in the total time frame, no aftereffects are included (see Eq. (9)). Therefore, the transformation factor can be simplified into:

$$
\delta_{m, m a t, j}= \begin{cases}\frac{E f f_{m} * a_{m, m a t} * e_{m, j}}{5}, & z_{m}=1 \\ \frac{a_{m, m a t} * e_{m, j}}{5}, & z_{m}=0\end{cases}
$$




\subsection{Calculation of the aggregated material flows and RESPOTs}

The resulting material flows are successively summarized over total time period $J_{t}$ and application area $B E R(\mathrm{RB}, \mathrm{NRB}$, road infrastructure):

$$
\operatorname{Sum}_{M_{d}, m a t}^{t}=\sum_{b e r \in B E R} \sum_{j \in J_{t}} S_{M_{d}, \text { ber,mat }, j}^{t}, \quad \forall m a t \in M A T
$$

Then, we summarize the material groups $\operatorname{Sum}_{M_{d}, \text { ber, }, j}^{t}$ (Eq. (22) and measure-specific material flows $\operatorname{Sum}_{M_{d}, g}^{t}$ in $J_{t}$ (Eq. (23) and aggregate it to the total sum of material flow reduction $\operatorname{Sum}_{M_{d}}^{t}$ by measures $M_{d}$ (Eq. (24):

$$
\begin{gathered}
\operatorname{Sum}_{M_{d}, \text { ber, }, j}^{t}=\sum_{m a t \in G_{f(\text { mat })}} S_{M_{d}, \text { ber,mat }, j}^{t} \quad \forall \text { ber } \in B E R, \forall g \in G, \forall j \in J \\
\operatorname{Sum}_{M_{d}, g}^{t}=\sum_{b e r \in B E R} \sum_{j \in J_{t}} S_{M_{d}, b e r, g, j}^{t}, \forall g \in G \\
\operatorname{Sum}_{M_{d}}^{t}=\sum_{g \in G} \operatorname{Sum}_{M_{d}, g}^{t}
\end{gathered}
$$

The results can be compared with the aggregated material flow results from the „plain“ business-asusual material flow model (see section 4.2):

$$
\begin{aligned}
& S u m_{m a t}^{b}=\sum_{b e r \in B E R} \sum_{j \in J_{t}} S_{\text {ber,mat }, j}^{b}, \forall m a t \in M A T \\
& \operatorname{Sum}_{b e r, g, j}^{b}=\sum_{m a t \in G_{f(m a t)}} S_{b e r, m a t, j}^{b} \quad, \quad \forall \text { ber } \in B E R, \forall g \in G, \forall j \in J \\
& \operatorname{Sum}_{g}^{b}=\sum_{b e r \in B E R} \sum_{j \in J_{t}} S_{b e r, g, j}^{b}, \forall g \in G \\
& \operatorname{Sum}^{b}=\sum_{g \in G} S_{g}^{b}
\end{aligned}
$$

The comparison shows the RESPOT of a bundle of measures $\operatorname{RESPOT}_{M_{d}}$ (Eq. (29)) and the resource reduction potential per material $\operatorname{Total}_{M_{d}, \text { mat }}$ (Eq. (30)):

$$
\begin{aligned}
\operatorname{RESPOT}_{M_{d}} & =\frac{\operatorname{Sum}^{b}-\operatorname{Sum}_{M_{d}}^{t}}{\operatorname{Sum}^{b}} \quad[\%] \\
\operatorname{Total}_{M_{d}, \text { mat }} & =\frac{\operatorname{Sum}_{\text {mat }}^{b}-\operatorname{Sum}_{M_{d}, \text { mat }}^{t}}{\operatorname{Sum}_{\text {mat }}^{b}}
\end{aligned}
$$




\section{Case study: German federal state of Baden-Württemberg (BW)}

\subsection{Description of the sample region}

The case study area is the German federal state of Baden-Württemberg (BW) with approximately 10.8 million inhabitants $(2015)^{32}, 4.458 .706$ social-insurance paying employees $(2016)^{33}, 2.4$ million RB $(2016)^{34}, 27,420$ supra-local road kilometres $(2017)^{35}$, and 35,751 square kilometres $\left.(2017)^{36}\right)$. BW is located in the south-west of Germany and consists of 35 rural and 9 urban districts. The average population density is 306 people $/ \mathrm{km}^{237}$. For this area, we applied the model described in section 4 . Baseline year for the MFA data is 2015; the model calculations and projections range from 2016-2030.

\subsection{Data}

For modelling the RB ${ }^{38}$ stock of BW, the StaBaWü 2016, Zensus 2011 and Mikrozensus 2010 datasets are used that might allow conclusions on the material composition (Destatis 2012). Data on construction periods, average residential unit size (StaBaWü 2016), material composition indicators, on vacancy and demolition rates (Banse and Effenberger 2006, Gruhler and Böhm 2011a) and on renovation rates of RBs (Deilmann et al. 2014) are used from literature (see section 4.2.1). Furthermore, projections on the housing market on district level are used from (BBSR 2015b). However, only coarse material composition information is available (BayLASD 2013) and localized analyses on material stocks are not available. The census data had to be extrapolated and the projection values on the housing market differ.

For the developed hybrid NRB stock estimation and projections until 2030, we use regional BW job statistics, general population statistics, school and kindergarden statistics, construction statistics, the Zensus 2011 database (BayLASD 2013) and building type-specific material compositions from synthetic

\footnotetext{
32 https://www.statistik-bw.de/BevoelkGebiet/Bevoelkerung/99025010.tab?R=LA, last access: 23 May 2018

33 https://www.statistik-bw.de/Arbeit/Beschaeftigte/LRt0504.jsp, last access: 23 May 2018

${ }^{34}$ https://www.statistik-bw.de/Wohnen/GebaeudeWohnungen/99045041.tab?R=LA, last access: 23 May 2018

35 https://www.statistik-bw.de/Statistik-Portal/de jb16 jahrtab36.asp, last access: 24 May 2018

${ }^{36}$ https://www.statistik-bw.de/BevoelkGebiet/GebietFlaeche/01515020.tab?R=LA, last access: 24 May 2018

37 This value ranges from 3,029 (Stuttgart) to 101 (Main-Tauber-Kreis). Most populous district is Rhein-Neckar-Kreis (544,400 inhabitants) and less populated district is Hohenlohekreis (110,689 inhabitants). Largest city and state capital is Stuttgart (628,032 inhabitants). The Ortenaukreis is the largest district $\left(1,861 \mathrm{~km}^{2}\right)$ and Tübingen the smallest $\left(519 \mathrm{~km}^{2}\right)$.

${ }^{38}$ All building with $>50 \%$ residential use of their total usage area are considered residential.
} 
buildings ${ }^{39}$ to break down national NRB stock information (section 4.2.1). To quantify NRB stock in the case study area, we cross-evaluated the employees in the districts with their economic departments and professional sectors (Statistik Südwest 2016) and assigned them to the NRB types. Due to data protection laws, the cross-evaluation is not available on district level and national values are used. This might cause uncertainties. If we could not derive the hybrid NRB stock, best available national indicators of Deilmann et al. 2013 were applied especially to more rural districts of the case study region (section 4.2.1). Furthermore, we consider district-specific vacancy rates. The vacancy rates and construction periods' distributions in NRBs are approximated with data for multi-family RBs from Zensus 2011 (section 4.2.1).

Also, freely available GIS data from the city of Hamburg and data from Schlomann et al. 2015 was evaluated to determine the share of non-residentially used gross building volumes $\left[\mathrm{m}^{3}\right]$ in RBs and administratively differentiated in urban and rural districts. For the Hamburg data, we calculated a share of $9.8 \%$ for urban districts. For rural districts, we use the national value of Schlomann et al. 2015 of $18 \%$ for rural districts. This share is added to all other RB gross volumes based on Zensus data in urban areas of the case study. Mostly, the indicator values of non-residentially used areas in RB of Hamburg were used for urban BW districts.

For the road infrastructure, the data on road types and construction works (tunnels, bridges) as well as their volumes and material stocks and flows are based in previous works (Knappe et al. 2015) (see section 4.2.2 for details). The material masses of roads were derived with information on the vertical surface layer structures of the roads per road type (incl. especially asphalt, concrete or paving stones). This was not regionally differentiated. For bridges type, main material and material intensity per bridge

\footnotetext{
${ }^{39}$ Synthetic building are based on previous works by IÖR 2018; Ortlepp et al. 2017, Deilmann et al. 2013, 2014, Schiller et al. 2010, 2015, Gruhler et al. (2002), Gruhler and Böhm 2011a,b; Buchert et al. 2004; Görg 1997, IWU 1994. They are representing the material composition of a "typical" representative of the designated building class, construction period and construction types for German building stock based on material analyses of Görg (1997) and IWU (1994) (Schiller et al. 2015, p. 98). The dataset is based on BKI database and empirically captured averaged values $\left[\mathrm{m}^{2}, \mathrm{~m}^{3}, \mathrm{~kg}\right.$ per material] for representative RB and NRB per type and construction period (e.g. from plans, photographs, specifications) (IÖR 2018, Ortlepp et al. 2017). Also, single buildings' values were used to complement the database.

Values used in literature are tonnes $\left[\mathrm{Mg} / \mathrm{m}^{3}\right]$ or kilograms $\left[\mathrm{kg} / \mathrm{m}^{3}\right]$ per gross volume $(\mathrm{GV})$ either per construction period, per construction type or per use type of the buildings (Schebek et al. 2017). Other studies refer to residential units [Mg/unit] (Schiller et al. 2010, Banse and Effenberger 2006) or residential living area $\left[\mathrm{Mg} / \mathrm{m}^{2}\right]$ (Schiller et al. 2015). The latter can be easier combined with the population statistics (Mikrozensus 2010).
} 
length were given (ca. $90 \%$ concrete, Knappe et al. 2015, p. 40). For tunnels, indicators of $13.73 \mathrm{t} / \mathrm{m}^{2}$ concrete and $1.39 \mathrm{t} / \mathrm{m}^{2}$ steel were used based on older studies. Knappe et al. 2015 also discuss the data quality (p. 31) and assign a good quality for the case study region (on a scale from not available, very bad, bad, medium, good, very good).

However, as in Knappe et al. 2015, material flows and projections are only given for administrative regions ("Regierungsbezirke"), the regional material flows on district level are derived from administrative region level by using the district-specific road lengths of the different road types in relation to their total respective road length. For the infrastructure structures (such as bridges or tunnels), the conversion is based on the share of all road construction in the districts in comparison to the entire region. The inaccuracy resulting from this can be classified as low.

The stakeholder assessment was performed with two successive surveys in Germany with a total of 88 valid responses. In the pre-survey (sent to 170 stakeholders), 10 full questionnaires could be evaluated and the set of key measures could be revised. The main survey was available online in the tool Unipark Questback between 16th February and 14th April 2017 and 40 responses could be evaluated. Based on the survey data, the effectivity of the 31 main resources-saving measures as well as the stakeholder impact on resource conservation and their mutual influence could be collected and calculated (see section 5.5 and Eq. (5)). Further surveys could improve the data availability and could be adapted in the model.

The underlying data is based on the best and most recent dataset for urban and rural districts in Germany. Nevertheless, uncertainties are prevailing (see also section 6.3), e.g. regarding the assumed material composition of buildings per type and construction period (see section 4.2) that is based on previous work (Banse and Effenberger 2006; Buchert et al. 2004; Deilmann et al. 2013, 2014; Görg 1997; Gruhler et al. (2002), Gruhler and Böhm 2011a,b; IÖR 2018; IWU 1994; Ortlepp et al. 2017; Schebek et al. 2017; Schiller et al. 2010, 2015) (see also footnote 39), regarding the projections on the housing market on district level (based on BBSR 2015b), the national values on NRB stock and its development (mainly based on Deilmann et al. 2013), the extrapolation of the census data, the regionalization of the national NRB stock data by indicators, Hamburg's GIS and statistical data, and 
missing data for local vacancy rates and age distributions of NRB for the case study region. An analysis of the most influential uncertainties and model parameters was performed within the following scenarios (see section 5.3) and is critically reflected in section 6.3.

\subsection{Scenarios}

Main influencing MFA parameters model are (a) the vacancy rates, (b) the demographic development and resulting demand for residential areas/units, (c) the renovation rate and (d) the replacement demand (Table 9, section 4.1). The calculated scenarios include a standard scenario with the demographic development according to (BBSR 2015a), with 0.15\% vacancy rate development per year in case of decreasing demand, with a renovation rate of $2.5 \%$ per year and a replacement demand of $0.2 \%$ (single family houses), $0.3 \%$ (multifamily houses) and for NRB ranging between $0.31 \%$ and $1.09 \%$ per year (Table 9).

For the road infrastructure, data of Knappe et al. 2015 was used. Main parameters are the settlement area development ( 30 ha/day), the target figures of federal roads, the recycling of asphalt, concrete/ pavement, unbound materials (varying between 25 and 100\%) and the renovation cycles (see Table 10). In the used reference scenario, a recycling rate of $75 \%$ for asphalt and unbound materials and of $100 \%$ for concrete/paving are assumed (Table 10). The growth of the settlement area describes new areas to be used for housing. The settlement area development varies between 0 and 50 ha/day based on Destatis (2017) with 66 ha/day on average between 2012-2015 and a politically targeted value of less than 30 ha/day by 2030 . It is directly connected to the construction of new roads as new settlement areas have to be made accessible.

\subsection{Material flow model results in the business-as-usual case until 2030}

In the Baden-Württemberg building stock, RB are dominated by light-weight materials, masonry and concrete, while NRB mainly consist of concrete with lower shares of light-weight materials and masonry (Table 11, Appendix Figure 18, Figure 9). The road infrastructure is dominated by unbound 
materials and asphalt, followed by concrete. The material flows resulting from the standard/reference scenario of the MFA model are shown in Table 12.

Table 9: Considered scenarios with their respective scenario parameters for RB and NRB

\begin{tabular}{|c|c|c|c|c|c|c|}
\hline \multirow{2}{*}{ No. } & \multirow{2}{*}{$\begin{array}{l}\text { Scenario } \\
\text { name }\end{array}$} & \multirow{2}{*}{ 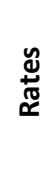 } & \multicolumn{4}{|c|}{ Scenario parameters } \\
\hline & & & $\begin{array}{l}\text { Demographic } \\
\text { development }\end{array}$ & $\begin{array}{l}\text { Vacancy rate } \\
\text { development }\end{array}$ & $\begin{array}{c}\text { Renovation rate } \\
\text { development }\end{array}$ & $\begin{array}{c}\text { Replacement demand } \\
\text { development }\end{array}$ \\
\hline 1 & $\begin{array}{l}\text { Standard } \\
\text { scenario, base }\end{array}$ & \multirow{3}{*}{$\begin{array}{l}\frac{0}{0} \\
\frac{0}{0} \\
\frac{0}{0} \\
\frac{1}{0} \\
\stackrel{n}{n}\end{array}$} & $\begin{array}{l}\text { Standard [BBSR } \\
\text { 2015] }\end{array}$ & $0.15 \% / a *$ & \multirow{3}{*}{$\begin{array}{c}\text { 2\%/a (NRB, similar to } \\
\text { RB) }\end{array}$} & \multirow{3}{*}{$\begin{array}{c}0.2 \% / a \\
\text { (Single family houses) } \\
0.3 \% / a \\
\text { (Multifamily houses) } \\
\text { Ranging from } 0.31 \% / a \\
\text { (other NRB) to } 1.09 \% \\
\text { (institutional buildings) }\end{array}$} \\
\hline 2 & $\begin{array}{l}\text { Optimistic } \\
\text { scenario, base }\end{array}$ & & $\begin{array}{l}\text { Minimum, acc. to } \\
\text { scenario } 1 \text { from } \\
\text { [Destatis 2015] }\end{array}$ & $0 \% / a *$ & & \\
\hline 3 & $\begin{array}{l}\text { Pessimistic } \\
\text { scenario, base }\end{array}$ & & $\begin{array}{l}\text { Maximum, acc. to } \\
\text { scenario } 8 \text { from } \\
\text { [Destatis 2015] }\end{array}$ & $0.3 \% / a *$ & & \\
\hline 4 & $\begin{array}{l}\text { Standard } \\
\text { scenario, } \min \end{array}$ & \multirow{3}{*}{$\frac{\xi}{\mathcal{E}}$} & $\begin{array}{l}\text { Standard [BBSR } \\
\text { 2015] }\end{array}$ & $0.15 \% / a *$ & \multirow{3}{*}{$\begin{array}{c}67 \% \text { of standard value } \\
(1.67 \% / \mathrm{a}(\mathrm{RB})) \\
(1.34 \% / \mathrm{a} \text { (NRB, similar } \\
\text { to } \mathrm{RB})) \\
(0.335 \% / \mathrm{a} \text { (other NRB)) }\end{array}$} & \multirow{3}{*}{$67 \%$ of standard value } \\
\hline 5 & $\begin{array}{l}\text { Optimistic } \\
\text { scenario, } \min \end{array}$ & & $\begin{array}{l}\text { Minimum, acc. to } \\
\text { scenario } 1 \text { from } \\
\text { [Destatis 2015] }\end{array}$ & $0 \% / a *$ & & \\
\hline 6 & $\begin{array}{l}\text { Pessimistic } \\
\text { scenario, min }\end{array}$ & & $\begin{array}{l}\text { Maximum, acc. to } \\
\text { scenario } 8 \text { from } \\
\text { [Destatis 2015] }\end{array}$ & $0.3 \% / a *$ & & \\
\hline 7 & $\begin{array}{l}\text { Standard } \\
\text { scenario, } \max \end{array}$ & \multirow{3}{*}{ 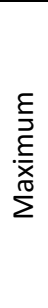 } & $\begin{array}{l}\text { Standard [BBSR } \\
\text { 2015] }\end{array}$ & $0.15 \% / a *$ & \multirow{3}{*}{$\begin{array}{c}133 \% \text { of standard value } \\
(3.33 \% / a(R B)) \\
(2.66 \% / a(N R B, \text { similar } \\
\text { to RB)) } \\
(0.665 \% / a \text { (other NRB)) }\end{array}$} & \multirow{3}{*}{$133 \%$ of standard value } \\
\hline 8 & $\begin{array}{l}\text { Optimistic } \\
\text { scenario, max }\end{array}$ & & $\begin{array}{l}\text { Minimum, acc. to } \\
\text { scenario } 1 \text { from } \\
\text { [Destatis 92015] }\end{array}$ & $0 \% / a *$ & & \\
\hline 9 & $\begin{array}{l}\text { Pessimistic } \\
\text { scenario, } \max \end{array}$ & & $\begin{array}{l}\text { Maximum, acc. to } \\
\text { scenario } 8 \text { from } \\
\text { [Destatis 2015] }\end{array}$ & $0.3 \% / a *$ & & \\
\hline
\end{tabular}

Table 10: Overview on road infrastructure scenarios for Germany (based on Knappe et al. 2015, p.63ff)

\begin{tabular}{|c|c|}
\hline & Reference scenario \\
\hline Settlement area development & 30 ha/day \\
\hline Planned forecast numbers for federal roads & Medium \\
\hline \multirow[t]{3}{*}{ Recycling of } & $75 \%$ \\
\hline & $100 \%$ \\
\hline & $75 \%$ \\
\hline \multirow{5}{*}{$\begin{array}{r}\text { lovation cycles (1000t/a, in Germany) } \begin{array}{r}\text { Asphalt } \\
\text { Pavement } \\
\text { Concrete }\end{array} \\
\text { Hydraulically bounded aggregates }\end{array}$} & 37.470 \\
\hline & 839 \\
\hline & 8.234 \\
\hline & 520 \\
\hline & 29.758 \\
\hline
\end{tabular}


Table 11: Material stock for residential and non-residential buildings as well as road infrastructure in Baden-Württemberg in 2016 (*: pavement; **: steel; ***: non-woven fabric)

\begin{tabular}{|c|c|c|c|}
\hline Sum Baden-Württemberg & $\begin{array}{l}\text { Residential buildings } \\
\text { (kg) }\end{array}$ & $\begin{array}{l}\text { Non-residential buildings } \\
\text { (kg) }\end{array}$ & $\begin{array}{l}\text { Infrastructure } \\
(\mathrm{kg})\end{array}$ \\
\hline Concrete & $7.09 \mathrm{E}+10$ & $1.49 \mathrm{E}+11$ & $5.63 \mathrm{E}+10$ \\
\hline Masonry (>2000 kg/m³) & $2.43 E+11$ & $3.28 \mathrm{E}+10$ & $1.22 \mathrm{E}+10^{*}$ \\
\hline Light-weight materials $\left(<2000 \mathrm{~kg} / \mathrm{m}^{3}\right)$ & $5.06 \mathrm{E}+11$ & $6.71 E+10$ & - \\
\hline Tiles (no concrete tiles) & $1.03 E+10$ & $2.59 E+08$ & - \\
\hline Gypsum & $2.55 \mathrm{E}+10$ & $2.47 E+09$ & - \\
\hline Unbound materials (stones esp. in road & & & $3.31 E+11$ \\
\hline works) & $6.81 E+09$ & $2.63 E+10$ & \\
\hline Glass & $8.95 E+09$ & $2.85 E+10$ & - \\
\hline Asphalt & $6.51 E+09$ & $6.61 E+08$ & $1.98 \mathrm{E}+11$ \\
\hline $\begin{array}{l}\text { Others (Screed, plasters, ceramics, } \\
\text { cladding etc.) }\end{array}$ & $2.48 \mathrm{E}+10$ & $5.11 \mathrm{E}+09$ & 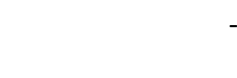 \\
\hline FE / Iron-based metals & $2.79 \mathrm{E}+09$ & $1.82 \mathrm{E}+10$ & $1.39 \mathrm{E}+10 * *$ \\
\hline Non-Ferrous metals & $6.18 \mathrm{E}+09$ & $6.29 E+08$ & - \\
\hline Timber (I+II) & $1.14 \mathrm{E}+10$ & $7.58 \mathrm{E}+09$ & - \\
\hline Timber (III+IV) & $8.97 E+08$ & $1.01 \mathrm{E}+09$ & - \\
\hline Plastics - PVC, EPS, PE, Others & $9.90 E+08$ & $1.46 \mathrm{E}+08$ & - \\
\hline Textiles & $2.22 \mathrm{E}+08$ & $1.74 \mathrm{E}+08$ & $4.09 \mathrm{E}+06 * * *$ \\
\hline Other C\&D waste & $3.06 \mathrm{E}+10$ & $1.93 E+10$ & - \\
\hline Total sum of materials & $9.55849 \mathrm{E}+11$ & $3.59239 E+11$ & $6.11404 E+11$ \\
\hline Gross volume $\left[\mathrm{m}^{3}\right]$ and length $[\mathrm{km}]$ & $2,589,248,511 \mathrm{~m}^{3}$ & $2,320,255,560 \mathrm{~m}^{3}$ & $87,458 \mathrm{~km}$ \\
\hline
\end{tabular}


Table 12: Material input and output for residential and non-residential buildings, as well as road infrastructure per inhabitant [capita] and year (without policy measures)

\begin{tabular}{|c|c|c|c|c|c|c|}
\hline $\begin{array}{l}\text { Sum Baden- } \\
\text { Württemberg }\end{array}$ & $\begin{array}{l}\text { Input RB } \\
2016-2030 \\
(\mathrm{~kg})\end{array}$ & $\begin{array}{l}\text { Output RB } \\
2016-2030 \\
\text { (kg) }\end{array}$ & $\begin{array}{l}\text { Input NRB } \\
2016-2030 \\
\text { (kg) }\end{array}$ & $\begin{array}{l}\text { Output } \\
\text { NRB 2016- } \\
2030(\mathrm{~kg})\end{array}$ & $\begin{array}{l}\text { Input road } \\
\text { infrastructure } \\
2016-2030(\mathrm{~kg})\end{array}$ & $\begin{array}{l}\text { Output road } \\
\text { infrastructure } \\
2016-2030(\mathrm{~kg})\end{array}$ \\
\hline Concrete & $2.55 \mathrm{E}+10$ & $3.71 \mathrm{E}+09$ & $2.54 \mathrm{E}+10$ & $1.79 \mathrm{E}+10$ & $2.53 \mathrm{E}+10$ & $2.12 \mathrm{E}+10$ \\
\hline Masonry $\left(>2000 \mathrm{~kg} / \mathrm{m}^{3}\right)$ & $5.53 E+10$ & $1.15 \mathrm{E}+10$ & $3.76 \mathrm{E}+09$ & $3.89 \mathrm{E}+09$ & $0.00 \mathrm{E}+00$ & $0.00 \mathrm{E}+00$ \\
\hline $\begin{array}{l}\text { Light-weight materials (< } \\
2000 \mathrm{~kg} / \mathrm{m}^{3} \text { ) }\end{array}$ & $5.02 \mathrm{E}+10$ & $3.36 \mathrm{E}+10$ & $2.43 E+09$ & $8.64 \mathrm{E}+09$ & $0.00 \mathrm{E}+00$ & $0.00 \mathrm{E}+00$ \\
\hline Tiles (no concrete tiles) & $2.01 E+09$ & $5.19 E+08$ & $6.70 \mathrm{E}+07$ & $1.34 \mathrm{E}+07$ & $0.00 \mathrm{E}+00$ & $0.00 \mathrm{E}+00$ \\
\hline Gypsum & $5.23 E+09$ & $1.30 \mathrm{E}+09$ & $2.81 \mathrm{E}+08$ & $3.20 \mathrm{E}+08$ & $0.00 \mathrm{E}+00$ & $0.00 \mathrm{E}+00$ \\
\hline $\begin{array}{l}\text { Unbound materials } \\
\text { (stones esp. in road } \\
\text { works) }\end{array}$ & $1.48 \mathrm{E}+09$ & $3.27 E+08$ & $4.53 E+09$ & $3.60 E+09$ & $7.83 \mathrm{E}+10$ & $5.70 \mathrm{E}+10$ \\
\hline Glass & $1.98 \mathrm{E}+09$ & $4.24 \mathrm{E}+08$ & $4.69 \mathrm{E}+09$ & $3.79 \mathrm{E}+09$ & $0.00 \mathrm{E}+00$ & $0.00 \mathrm{E}+00$ \\
\hline Asphalt & $3.49 \mathrm{E}+08$ & $1.33 \mathrm{E}+08$ & $2.32 \mathrm{E}+07$ & $1.15 \mathrm{E}+08$ & $8.02 \mathrm{E}+10$ & $6.64 \mathrm{E}+10$ \\
\hline $\begin{array}{l}\text { Others (Screed, plasters, } \\
\text { ceramics, cladding etc.) }\end{array}$ & $5.07 E+09$ & $1.26 \mathrm{E}+09$ & $5.81 E+08$ & $6.62 \mathrm{E}+08$ & $0.00 \mathrm{E}+00$ & $0.00 \mathrm{E}+00$ \\
\hline FE / Iron-based metals & $1.09 \mathrm{E}+09$ & $1.60 \mathrm{E}+08$ & $2.76 \mathrm{E}+09$ & $2.28 \mathrm{E}+09$ & $3.32 \mathrm{E}+09$ & $2.17 \mathrm{E}+09$ \\
\hline Non-Ferrous metals & $1.75 E+09$ & $2.51 \mathrm{E}+08$ & $8.19 E+07$ & $8.37 \mathrm{E}+07$ & $0.00 \mathrm{E}+00$ & $0.00 \mathrm{E}+00$ \\
\hline Timber (I+II) & $1.90 \mathrm{E}+09$ & $5.10 \mathrm{E}+08$ & $1.02 \mathrm{E}+09$ & $8.57 \mathrm{E}+08$ & $0.00 \mathrm{E}+00$ & $0.00 \mathrm{E}+00$ \\
\hline Timber (III+IV) & $1.44 \mathrm{E}+07$ & $6.93 \mathrm{E}+07$ & $1.36 \mathrm{E}+08$ & $1.14 \mathrm{E}+08$ & $0.00 \mathrm{E}+00$ & $0.00 \mathrm{E}+00$ \\
\hline $\begin{array}{l}\text { Plastics - PVC, EPS, PE, } \\
\text { Others }\end{array}$ & $2.32 E+08$ & $4.65 \mathrm{E}+07$ & $1.97 \mathrm{E}+07$ & $1.99 \mathrm{E}+07$ & $0.00 \mathrm{E}+00$ & $0.00 \mathrm{E}+00$ \\
\hline Textiles & $5.07 \mathrm{E}+07$ & $1.07 \mathrm{E}+07$ & $2.40 \mathrm{E}+07$ & $2.39 \mathrm{E}+07$ & $8.72 \mathrm{E}+05$ & $6.35 \mathrm{E}+05$ \\
\hline Other C\&D waste & $6.73 E+09$ & $1.46 \mathrm{E}+09$ & $3.20 \mathrm{E}+09$ & $2.58 \mathrm{E}+09$ & $0.00 \mathrm{E}+00$ & $0.00 \mathrm{E}+00$ \\
\hline Total sum [kg] & $1.59 \mathrm{E}+11$ & $5.53 E+10$ & $4.90 \mathrm{E}+10$ & $4.49 \mathrm{E}+10$ & $1.87 E+11$ & $1.47 \mathrm{E}+11$ \\
\hline Total sum [million tons] & 159 & 55.3 & 49 & 44.9 & 187 & 147 \\
\hline $\begin{array}{l}\text { Total sum per year } \\
\text { [million tons per year] }\end{array}$ & 11.4 & 4.0 & 3.5 & 3.2 & 13.4 & 10.5 \\
\hline $\begin{array}{l}\text { Increasing stock by } \\
\text { construction (positive) } \\
\text { or decreasing stock by } \\
\text { demolition (negative) in } \\
\text { [tons per inhabitant and } \\
\text { year] }\end{array}$ & 14.71 & 5.12 & 4.54 & 4.16 & 17.33 & 13.59 \\
\hline $\begin{array}{l}\text { Net accumulation or } \\
\text { reduction of stock in } \\
\text { [tons per capita and } \\
\text { year] }\end{array}$ & \multicolumn{2}{|c|}{9.59} & \multicolumn{2}{|c|}{0.38} & \multicolumn{2}{|c|}{3.74} \\
\hline
\end{tabular}

With the output/input ratio (Figure 8 , blue), we identified structurally different districts (A: $<0.45, B$ : 0.45-0.75 and C: $>0.75$ ) with differing development profiles. Type A districts have a net material input in 2016-2030 both in RB and NRB. Type B districts have a net increasing RB stock, but a stagnating or shrinking NRB stock. Type C districts have a net stagnating RB stock and a stagnating or shrinking NRB stock in the considered period. A necessary distinction in regions with growth, steady state and shrinkage for different urban mining strategies is also mentioned by Brunner (2011). 


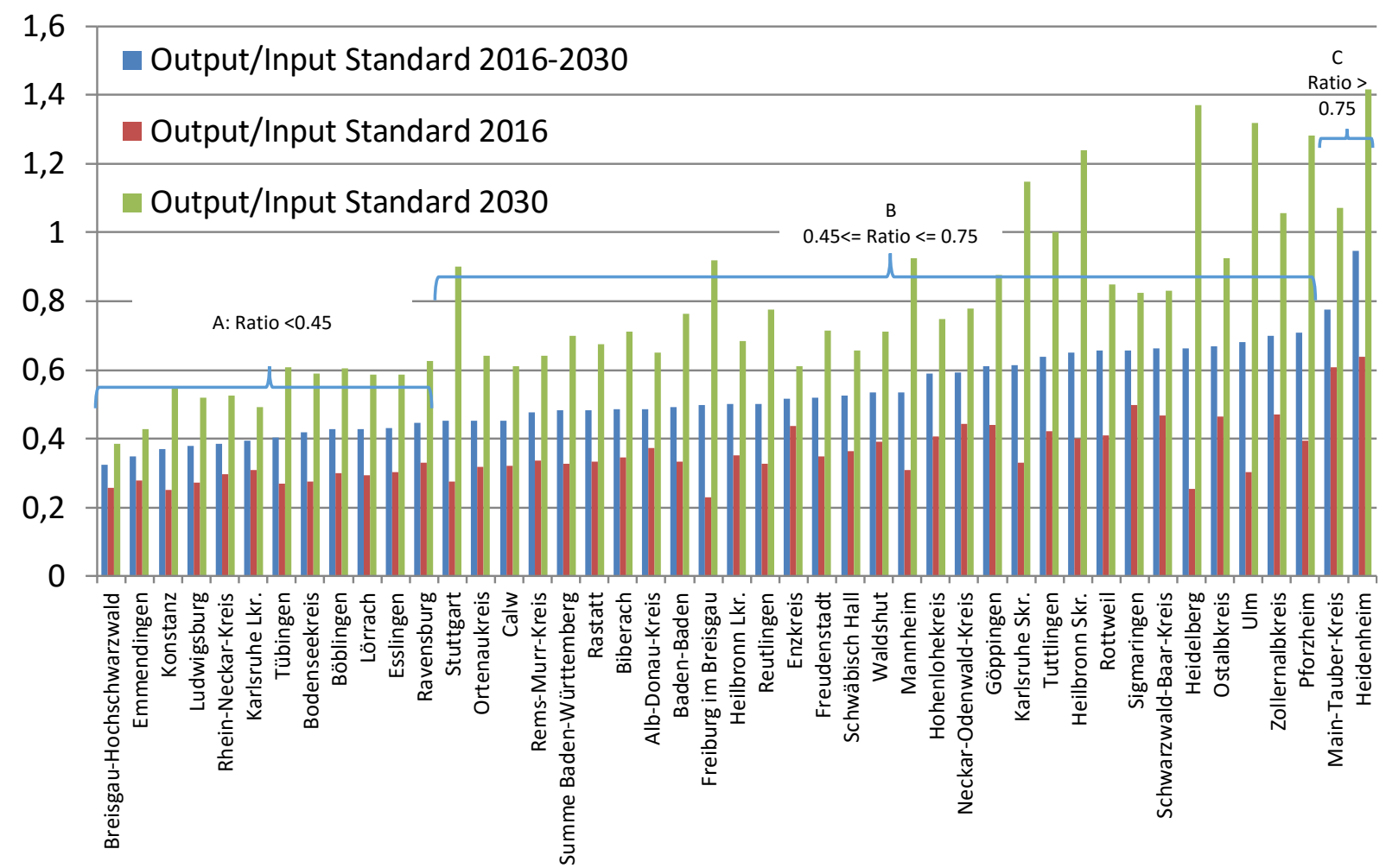

Figure 8: Input per output ratio of all materials in buildings of Baden-Württemberg, in 2016 (red) and 2030 (green) as well as cumulated for 2016-2030 (blue) for the standard scenario

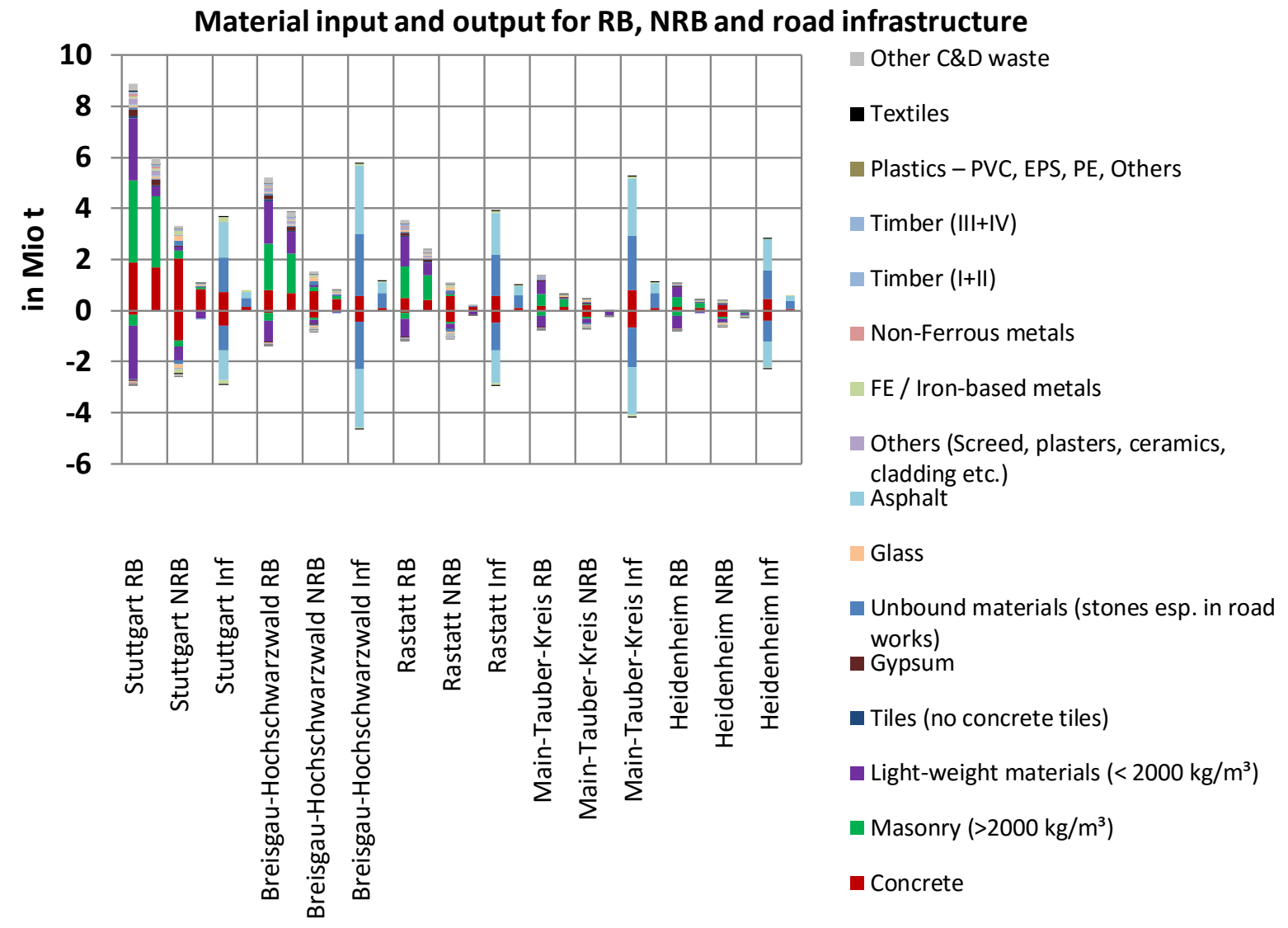

Figure 9: Material input and output for different application areas (BER) of residential and non-residential buildings as well as road infrastructure in selected, representative districts of each type, cumulated between 2016 - 2030 
A regional disparity could be found in the material output per required input material fraction ${ }^{40}$ that is needed in recycling concrete (Figure 10). For future material autonomy, an output per input ratio of $>=1$ is necessary due to material losses in RC processes and available in all districts on average per year. For some districts, the output and demanded input fit quite well (e.g. district types A), but for others this value differs greatly (district types $\mathrm{C}$ ). The material balance also shows a regional disparity (Figure 11) and a decreasing material balance in all three scenarios (Figure 12).

In all scenarios, the material inputs and balances vary by ca. 3 million tons/a during the evaluated period. The material stock (Table 11, Figure 18) and flows (Table 12, Figure 8, Figure 9) show a constant positive, yet decreasing material input in 2016-2030 (Figure 12). In the output material flows, the variation is lower and increases in later years. With maximum replacement and retrofit rates, the material input and output increase by 2-2.5 million tons/a, while with minimum parameters a respective reduction is projected.
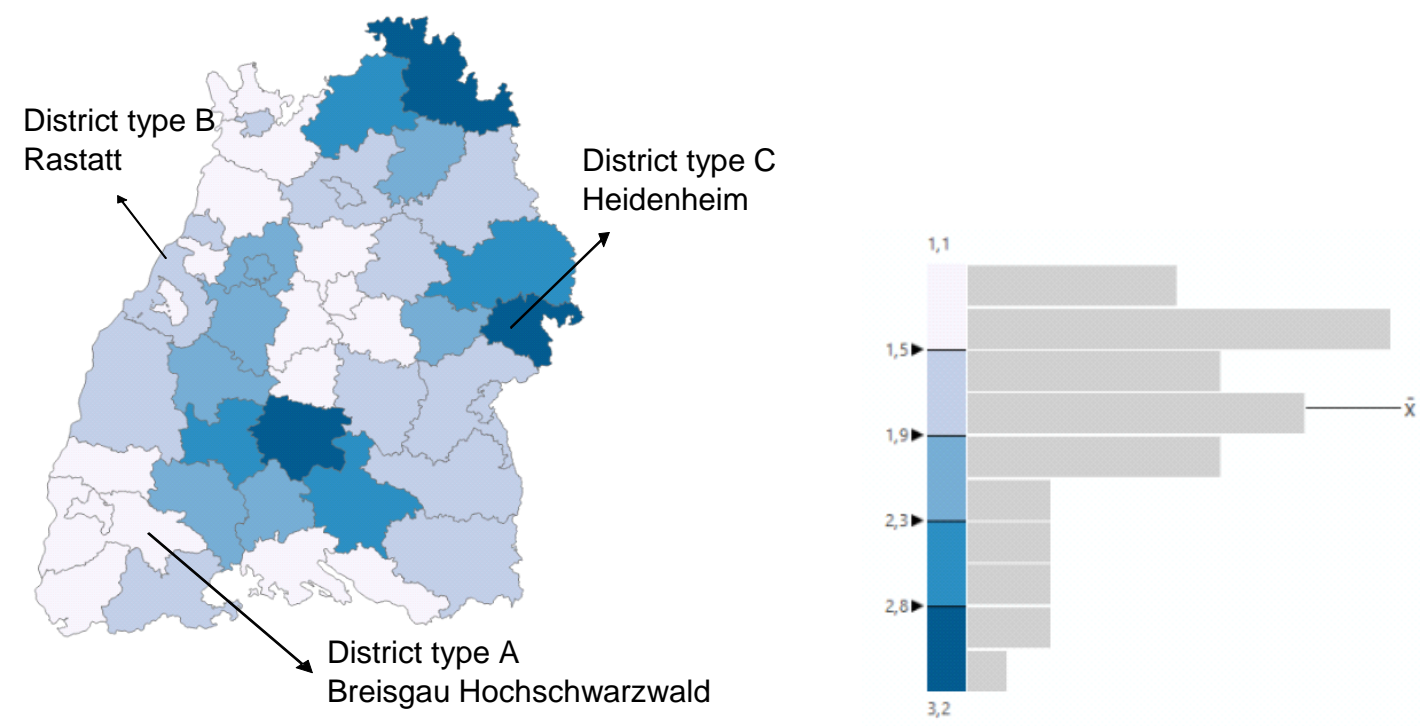

Figure 10: Average output per input ratio of aggregate that can be recycled in recycling concrete for buildings (average output over the years 2016-2030 and projected demand for input aggregate in recycling concrete), equally distributed intervals

\footnotetext{
${ }^{40}$ This calculation is based on the standard recycling concrete where $30 \%$ of total aggregate in concrete can be substituted by recycled material (Type II). According to the composition of the C25/30 standard concrete (Stürmer and Kulle 2017), the amount of total aggregates is $1.833 \mathrm{~kg} / \mathrm{m}^{3}$. Thereof, $30 \%\left(550 \mathrm{~kg} / \mathrm{m}^{3}\right)$ can be substituted by recycled aggregate $(=23 \%$ of the mass).
} 

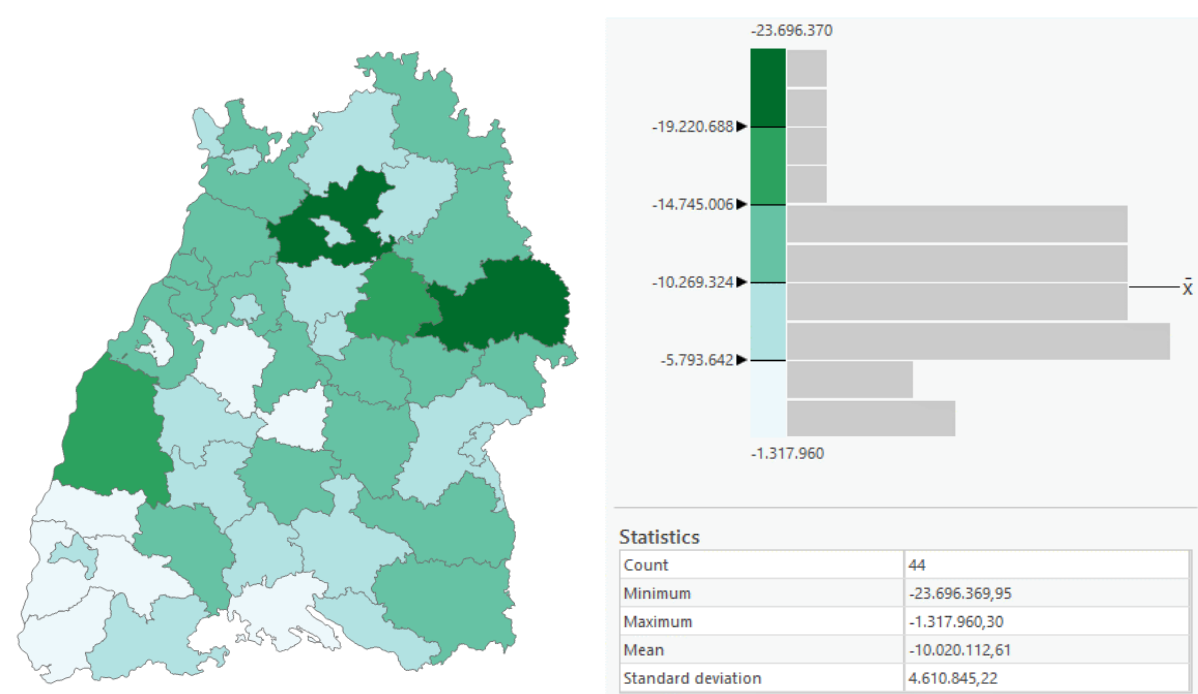

Figure 11: Average annual material balance in 2016-2030 of buildings regarding recycling concrete for Baden-Württemberg districts, equally distributed intervals

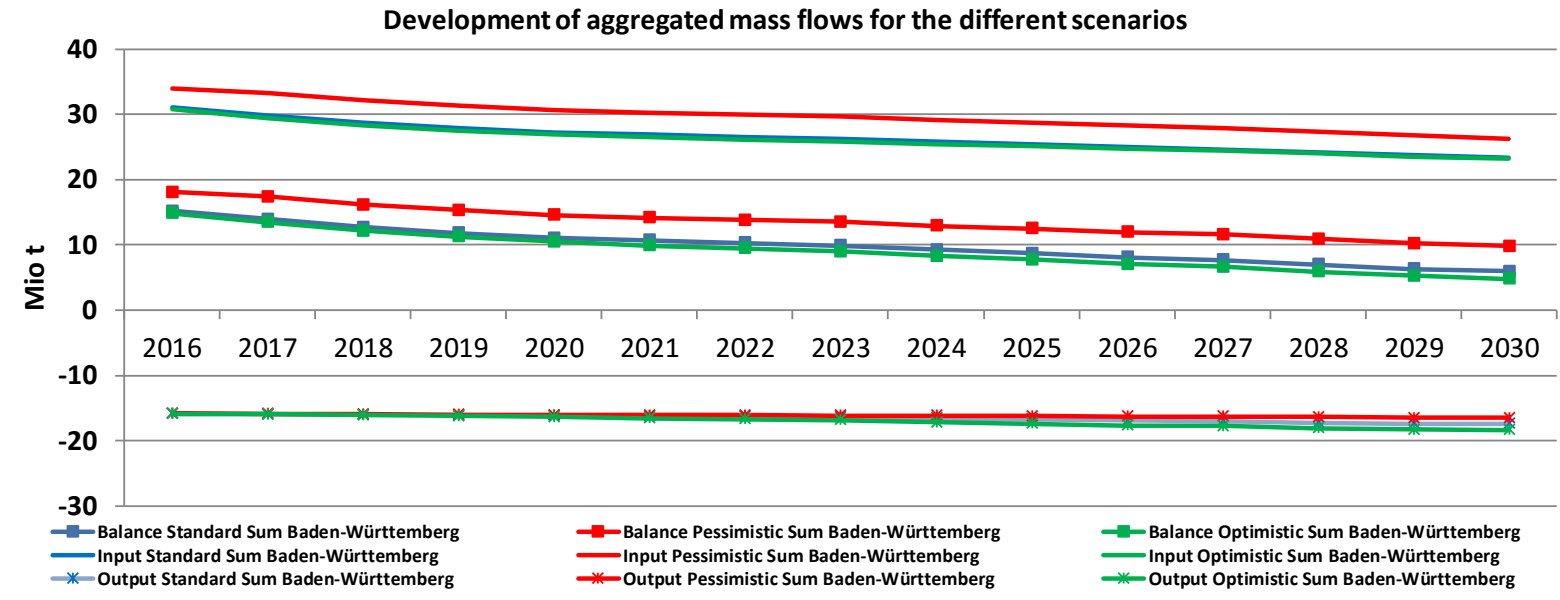

Figure 12: Trend of material input (line), outputs (stars) and the balance (squares) for the three main scenarios (blue: standard scenario; red: pessimistic scenario, green: optimistic scenario) for buildings and roads in Baden-Württemberg in the considered time frame with medium values for replacement and renovation

Comparing the model results with net construction growth or decrease rate of other references for plausibility, we see the following: Schiller et al. (2010) expect a net building stock reduction until 2050 despite a current growth in Germany's anthropogenic material stock of 10 tons/a*capita (Schiller et al. 2017c). This is confirmed/exceeded by our model results. On average, we calculate a net material stock growth in Baden-Württemberg of 9.59 tons/a*capita in RB, 0.38 tons/a*capita in NRB and 3.74 tons/a*capita in road infrastructure in 2018-2030 (see Table 12). Baden-Württemberg has economic and population growth, but our results indicate a decrease of material accumulation over 
time and a variation between districts. 42 of 44 districts have a projected net stock growth rate until 2030 and output/input ratios in buildings range between 0.4 and 1. Only in the districts Main-TauberKreis and Landkreis Heidenheim a net reduction is forecasted (output/input = 1.05 and 1.2). Thus, the MFA model results do not show any implausibility in this regard. On national level, Schiller et al. (2017a) projected outflows of ca. 24 million tons per year for Germany with a loss of 11.4 million tons per year (Schiller et al. 2017a, p. 125f.). For Baden-Württemberg, this results in ca. 6.4 million tons of outflows incl. losses of 3.3 million tons per year of high quality secondary aggregates when related to demographic numbers. Our model calculates accumulated outflows of 55.3 million tons for RB, 44.9 million tons for NRB and 147 million tons for the road infrastructure in the period of 2016-2030. This results in annual outflows of 4.0 million tons for RB, 3.2 million tons for NRB and 10.5 million tons for the road infrastructure (on average) (see Table 12). Furthermore, Schiller et al. 2017a calculate a mismatch of 3.2 Giga tons of supply and demand for Germany in 2020. As they do not provide figures on district level, a detailed comparison with Baden-Württemberg's districts is not possible.

Also, the urban and rural development disparities due to urbanization leaving behind underused buildings and roads (Fishman et al. 2015) can be seen in our model results. The model results show that the highest new construction rates compared to the existing stock are in rural areas around metropolitan regions (both for RB and NRB). However, according to Augiseau and Barles (2017, p.161), secondary resources could only marginally substitute primary resources in cities like Vienna or Orléans, even if recycling rates increase. Our results don't confirm this. On the contrary, the material output is sufficient to fully supply the recycled concrete production (see footnote 40 , section 5.3 ).

\subsection{StAR model results until 2030}

For calculation of the effects of resource conservation measures and industrial ecology policies (see Table 15 for the list of measures), up to three measures can be selected for simulation (Figure 13, left). 

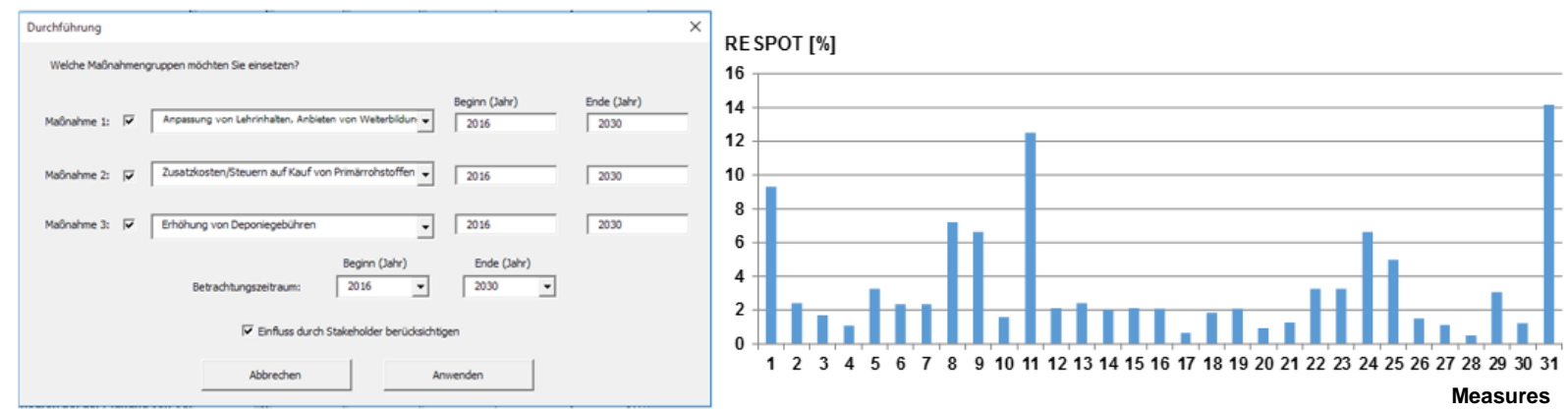

Figure 13: Selection of resource conservation measures for simulation in a graphical user interface (left) and model results for the cumulated resource conservation potential (RESPOT) [\%] for the considered single, unbundled 31 measures between 2018 and 2030 in the standard scenario for Baden-Württemberg (see Table 15 for the list of measures in the Appendix)

In the standard scenario, measure 31 (additional cost or taxes on primary resources) has the highest singular RESPOT with 14.2\% in the case study region (Figure 13, right). This is followed by measure 11 (increase of disposal fees) with $12.5 \%$ and measure 1 (adaption of curriculae of e.g. architects and engineers for environmental awareness) with 9.3\%. Bundling of these three measures lead to a combined RESPOT of $30.8 \%$ for the case study area Baden-Württemberg including the interdependences (Figure $14^{41}$ and Table 14 for different scenario results). The reductions of the three combined measures 31,11 and 1 have a varying impact on material categories and range from $17-42 \%$, depending on the material category (Table 13). Also, we found a strong positive, reinforcing bundling effect between measures 1 and 11 .

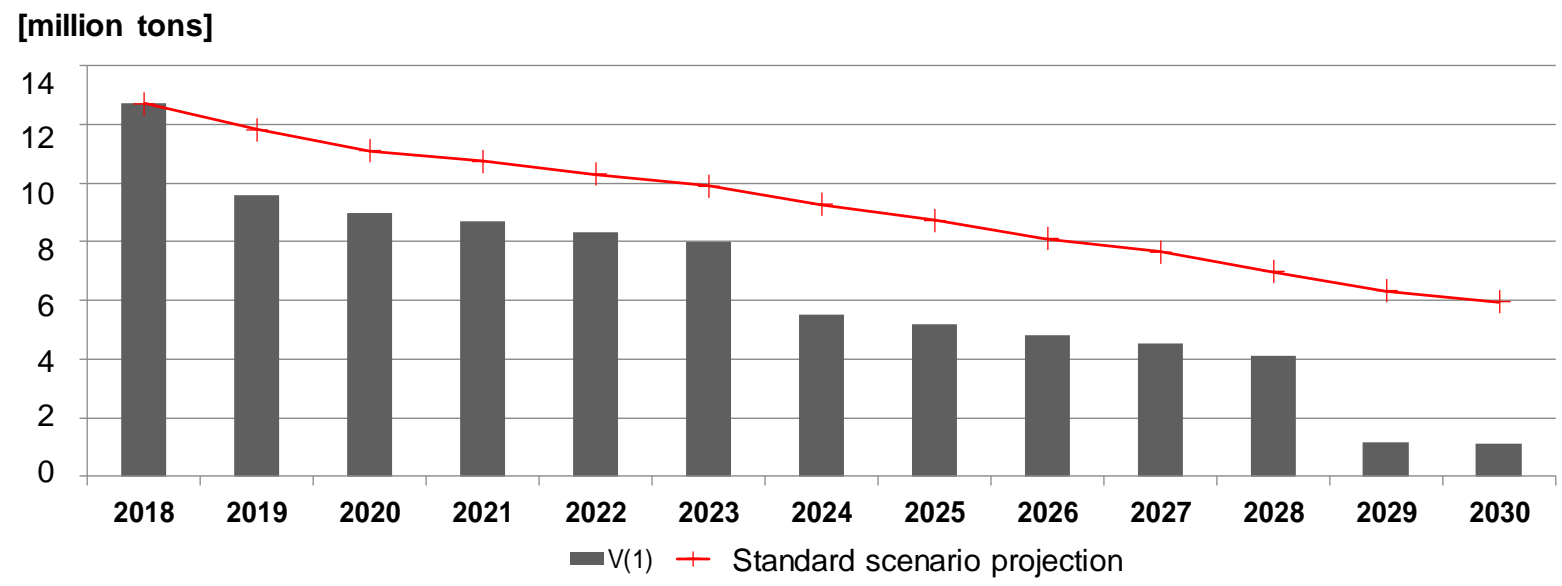

Figure 14: Standard scenario of material flows [million tons] (red line) and reduced material flows [million tons] with measure bundle V(1) of measures 31, 11 and 1 (top three measures) (grey bars) and resulting potential resource conservation for Baden-Württemberg.

\footnotetext{
${ }^{41}$ Figure 14 is calculated for each district and accumulated for the whole region by the model.
} 
The top three measure bundle of $V(1)=\left\{m_{1}, m_{2}, m_{3}\right\}$ could lead to a reduction of cumulated material flow balances for the years 2018-2030 from the baseline aggregated material flows of 119 million tons (red line) to an anticipated, reduced material flow of 82 million tons (sum of grey bars) (see Figure 14). The grey bars represent the material flow balance for the respective year. It can be seen that the measures only take a few years to develop and, with increasing time since their initial introduction, they have increasing effects on the material flows. Thus, the gaps between the baseline forecast of the standard scenario projection (red) and the reduced forecast (grey) are steadily increasing, e.g. due to certain start-up times until the structures or the related processes in the C\&D industry change.

Table 13: Cumulated material flows (2018-2030) in standard scenario with potential resource conservation per material category [\%] by top three measures 31,11 and 1

\begin{tabular}{|l|l|l|}
\hline Material & Sum [million tons] & Reduction [\%] \\
\hline Concrete & 18.3 & 29.7 \\
\hline Masonry $\left(>2000 \mathrm{~kg} / \mathrm{m}^{3}\right)$ & 24.3 & 31.4 \\
\hline Light-weight materials $\left(<2000 \mathrm{~kg} / \mathrm{m}^{3}\right)$ & 5.8 & 17.3 \\
\hline Tiles (no concrete tiles) & 0.9 & 32.0 \\
\hline Gypsum & 2.2 & 31.3 \\
\hline Unbound materials (stones esp. in road works) & 13.0 & 34.8 \\
\hline Glass & 1.3 & 25.2 \\
\hline Asphalt & 7.8 & 35.3 \\
\hline Others (Screed, plasters, ceramics, cladding etc.) & 2.1 & 30.7 \\
\hline FE / Iron-based metals & 1.4 & 29.0 \\
\hline Non-Ferrous metals & 0.8 & 31.7 \\
\hline Timber (I+II) & 0.9 & 30.4 \\
\hline Timber (III+IV) & -0.02 & 42.8 \\
\hline Plastics - PVC, EPS, PE, Others & 0.1 & 31.4 \\
\hline Textiles & 0.02 & 28.7 \\
\hline Other C\&D waste & 3.3 & 30.2 \\
\hline
\end{tabular}

Table 14: Scenario results for baseline material flow projection (without policy measures) and the calculated resource conservation potential (RESPOT) with bundled most effective policy measures 1, 11 and 31 for Baden-Württemberg, per scenario

\begin{tabular}{|c|c|c|c|c|c|c|c|}
\hline \multirow[t]{3}{*}{ Scenario } & \multirow{2}{*}{$\begin{array}{l}\text { Baseline material } \\
\text { flow balance } \\
\text { projection } \\
\text { without } \\
\text { measures (2018- } \\
\text { 2030) }\end{array}$} & \multicolumn{3}{|c|}{$\begin{array}{l}\text { Singulary RESPOT } \\
\text { of measure }\end{array}$} & \multirow{2}{*}{$\begin{array}{l}\text { Material flow balance } \\
\text { projection with measure } \\
\text { bundle } 1,11 \text { and } 31 \\
\text { (application period of } \\
\text { measures: 2019-2030) }\end{array}$} & \multirow{2}{*}{$\begin{array}{l}\text { Potential } \\
\text { reduction of } \\
\text { material } \\
(2018-2030)\end{array}$} & \multirow{2}{*}{$\begin{array}{l}\text { RESPOT with } \\
\text { bundling of } \\
\text { policy } \\
\text { measures 1, } \\
11 \text { and } 31\end{array}$} \\
\hline & & 1 & 11 & 31 & & & \\
\hline & [million tons] & {$[\%]$} & [\%] & {$[\%]$} & [million tons] & [million tons] & [\%] \\
\hline $\begin{array}{l}\text { Optimistic } \\
\text { scenario }\end{array}$ & 102 & 9.2 & 12.1 & 13.5 & 72 & 30 & 29.6 \\
\hline $\begin{array}{l}\text { Standard } \\
\text { scenario }\end{array}$ & 119 & 9.3 & 12.5 & 14.2 & 82 & 37 & 30.8 \\
\hline $\begin{array}{l}\text { Pessimistic } \\
\text { scenario }\end{array}$ & 172 & 9.6 & 13.1 & 15.2 & 116 & 56 & 32.4 \\
\hline
\end{tabular}


Other measures such as legal measures (8) Introduction of a minimum quota for the use of RC building materials in new buildings and (9) Introduction of a landfill ban on recyclable material as well as financial measures (24) New financial products/loans/subsidies for resource efficient construction and (25) More funds for remediation programs to increase redevelopment rates are less potent than measures 1, 11 and 31 (see Figure 13).

According to the survey results, financial measures have the largest RESPOT while the lowest effect until 2030 is expected by R\&D measures. Comparing the policy measures within the five measure categories, we see that financial measures $V(5)$ (see Figure 15), can have the strongest effect on resource conservation. The top three financial measures are measure (31) additional costs/ taxes on the purchase of primary raw materials, measure (11) increase of landfill fees and measure (24) new financial products/ loans/ subsidies for resource-efficient construction (e.g. recycling products are not considered as an additional risk). Bundled measures 31,11 and 24 have a combined RESPOT of $19.9 \%$ in the application period of 2019-2030 (see Figure 15).

The weakest influence until 2030 seem to have measures to promote research and development (R\&D) $V(2)$. The top three R\&D policy measures are measure (13) promotion of R\&D of new environmentally and recyclable building materials to replace "non-recyclable" building materials, measure (12) R\&D for recycling technology, new processes and machinery and measure (14) R\&D of improved construction processes (resource savings through better use of materials, or less offcuts/ waste). Bundled measures 13,12 and 14 have a combined RESPOT of $4.4 \%$ in the application period of 2019-2030. However, effects of R\&D and disruptive innovations is rather difficult to estimate.

The 82 million tons of construction materials, that are projected to enter the Baden-Württemberg stock between 2018 and 2030, consists of 24.3 million tons of masonry, 18.3 million tons of concrete and 13.0 million tons of unbound materials. The policy measures would lead to resource conservation especially regarding timber, asphalt, screed, plaster and clay and other materials. Timber demand of category III and IV could be reduced by ca. $43 \%$ and turned into a positive balance (less input than 
output). For the other material categories, the model calculates ca. $30 \%$ reduction potential, except for glass (ca. $25 \%$ ) and light-weight materials (ca. $17 \%$ ).

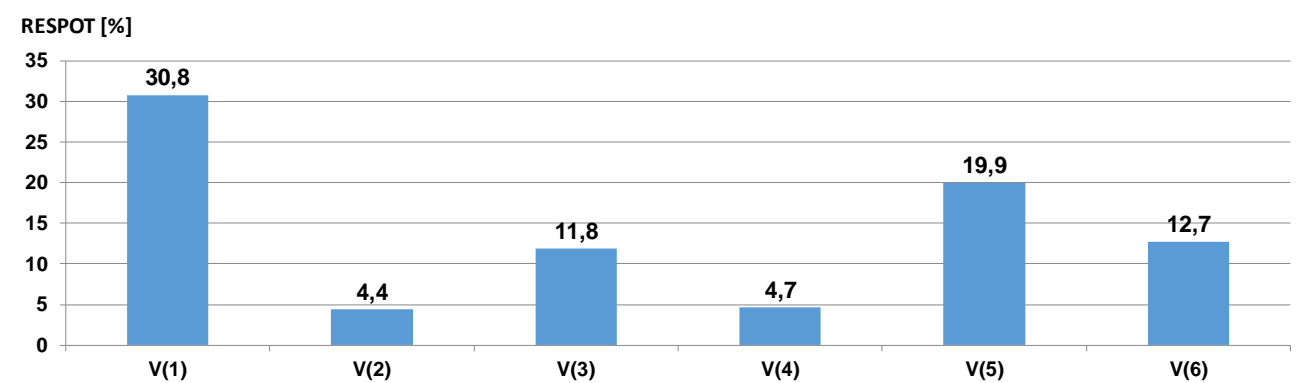

\begin{tabular}{|l|l|l|l|l|l|l|}
\hline Bundle of measures & Version V(1) & $\mathbf{V ( 2 )}$ & $\mathbf{V ( 3 )}$ & $\mathbf{V ( 4 )}$ & $\mathbf{V ( 5 )}$ & $\mathbf{V ( 6 )}$ \\
\hline Measure categories & All measures & $\begin{array}{l}\text { R\&D } \\
\text { measures }\end{array}$ & $\begin{array}{l}\text { Information } \\
\text { measures }\end{array}$ & $\begin{array}{l}\text { Organisation } \\
\text { al measures }\end{array}$ & $\begin{array}{l}\text { Financial } \\
\text { measures }\end{array}$ & $\begin{array}{l}\text { Legal } \\
\text { measures }\end{array}$ \\
\hline \multirow{2}{*}{$\begin{array}{l}\text { Top three measures } \\
\text { (sorted according to } \\
\text { descending order of } \\
\text { their effect) }\end{array}$} & 31 & 13 & 1 & 6 & 31 & 8 \\
\cline { 2 - 7 } & 1 & 12 & 23 & 7 & 11 & 9 \\
\hline
\end{tabular}

Figure 15: Comparison of maximum RESPOT (2019-2030) for bundled top three measures within all measure categories $V(1)-V(6)$ as well as for all measures in the standard scenario

Per rural and urban district, we can see the baseline projections until 2030 for the overall top three policy measures (see Figure 16 for sample districts Breisgau-Hochschwarzwald (type A), Raststatt (type B) and Heidenheim (type C)).

Comparing the StAR model results with Deilmann et al. 2014 for plausibility, we see the following: Until 2030, no change in new construction is projected, but in retrofitting and demolition a considerable trend reversal of $+50 \%$ from 2010 to 2030 is projected (Deilmann et al. 2014, p. 97ff). This is confirmed by our results. After $2030, \mathrm{RC}$ material use is projected to rise to a peak of $18-20$ million tons and to lower to $12-14$ million tons until 2050 due to reduced new construction. In 2030, a RESPOT by primary raw material substitution of $7 \%$ is projected (with the same RC rates like in 2010). In the sustainability scenario, $13 \%$ is calculated by Deilmann et al. (2014). Recycling rates are projected to lead to $16-21 \%$ (2030) and to $21-28 \%$ (2050) resource conservancy according to Deilmann et al. (2014). Our model results lead to a RESPOT of 30.8\% assuming the business-as-usual development plus the top three measures. 


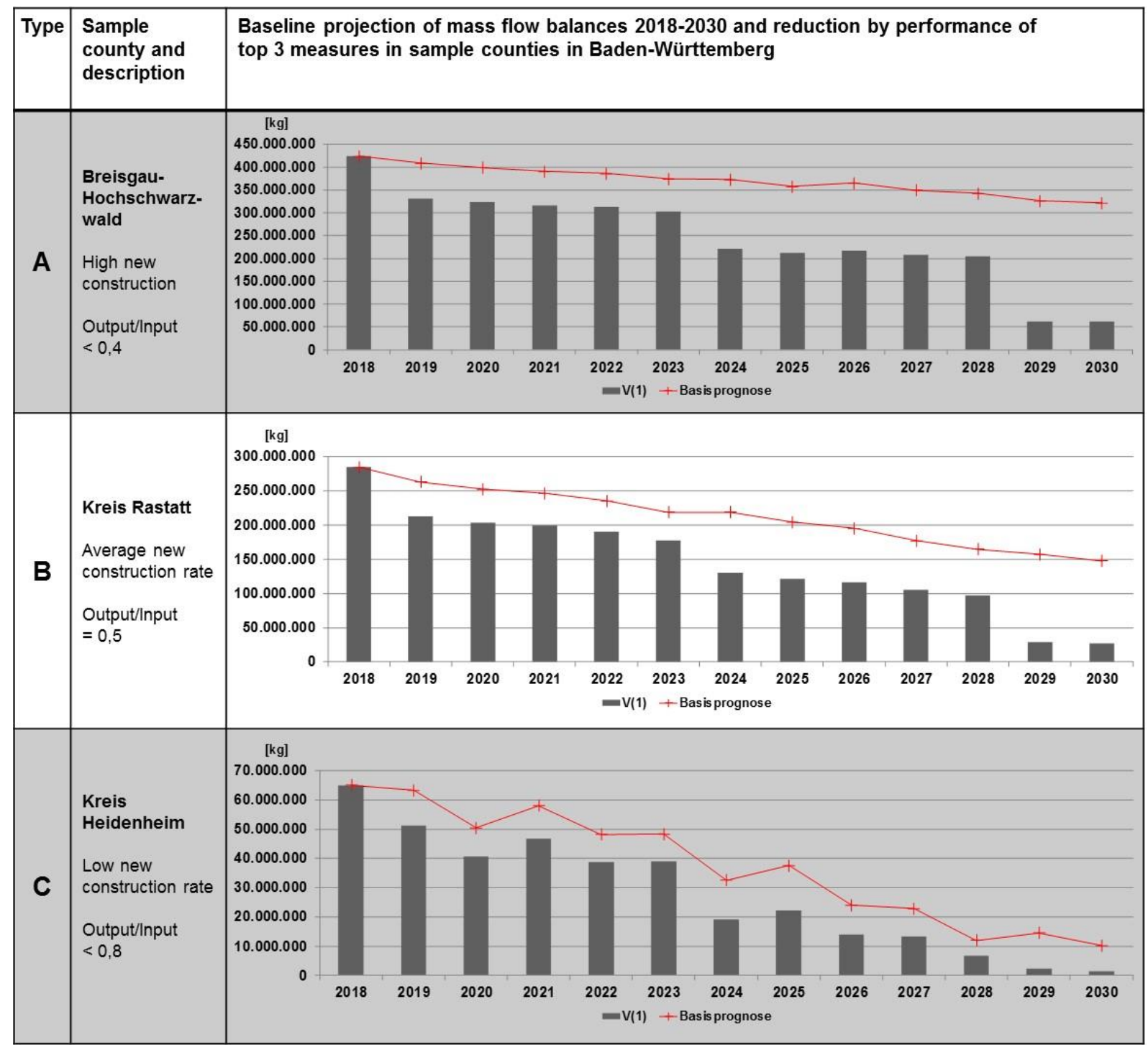

Figure 16: Basic material flow results (red line = Basisprognose / standard scenario projection) and RESPOT results for measure bundle $V(1)$ of measures 31, 11 and 1 (top three measures) (grey bars) in representative type counties $A, B$ and $C$ in Baden-Württemberg (2018-2030) (application period of measure bundle: 2019-2030)

\section{Discussion}

\subsection{Methodological development}

The aim of this study was to develop a model that combines material stock and flow analysis with policy measure and stakeholder modelling (StAR model) for the first time in order to identify spatially located inflows, outflows and resource conservation potential (RESPOT) in the building and infrastructure stock and to assess the stakeholders' and policy measures' influence on these material 
flows. The material stock and flow analysis uses existing national building stock modelling approaches, but also develops a new hybrid approach for quantifying materials in NRBs.

From the methodological aspect, we propose a new, unprecedented way of integrating empirical survey results, balanced score card and material flow analysis. We learnt in scientific terms, that the isolated modelling and consideration of material stocks and flows in the building and construction sector does not provide enough insights into potentials for system change. Only the integration of policy measures, their interactions and effects as well as the stakeholders, their objectives, their decision making and the resulting material flows provide understanding of the system as well as supply and demand for recycled C\&D materials (e.g. see Table 14). In the scenario calculations, the model results and insights seem plausible. The scenario analysis provides a range of probable future developments. However, disruptive developments like technical innovations or influencing factors like changing policies, global trends and human behaviour are not fully considered. But, all comparable material flow models in literature have similar assumptions and restrictions on the MFA modelling (see sections 6.3.2), a fragmentary and partly uncertain database (see sections 6.2.1, 6.2.2) and lack a validation (see section 6.2.3) especially on regional level (Wu et al. 2014, Schiller et al. 2017b) to evaluate the applied quantification methodologies. Thus, this has to be integral part of future research. We performed some uncertainty analyses (e.g. with different demand prognosis for buildings or different vacancy and retrofit rates) showing robust results. However, comprehensive tests on the robustness of the model, e.g. with changes of the empirical study results should be part of future research. Sensitivity analyses showed that demographic development had the highest effect on material input into RB (2016-2030). Regarding the material output and NRB however, the replacement rate is most influential (+/- 30\%). Also, we found a sensitivity regarding the vacancy rate development in the case of decreasing demand for NRB. 


\subsection{Database and system boundaries}

\subsubsection{Lacking data}

Still, data on NRB (age structure, vacancy rates), material composition indicators of earlier construction periods (before 1979), profound retrofit data, (statistical) demolition and waste data as well as extensive, cadastral GIS data for inventorying the building and infrastructure stock is lacking. Still, availability and quality of bottom-up data on renovations and demolitions in building stocks and infrastructure networks is an issue, because they are not subject to monitoring of public authorities (see also Schiller et al. 2017a) and are often expressed in monetary terms, but not in $\mathrm{m}^{2}$ or kg (Augiseu and Barles 2017, p. 159). Comparable datasets for urban or rural districts are not available for validation (e.g. Schiller et al. 2017a,b also do not provide detailed information). This should be part of future research.

In the new approach, the NRB stock composition on district level is derived from an assignment of regional statistics to NRB types and from indicators extracted from an available GIS based urban model $^{42}$ (see section 4.2.1 and section 6.3 for the discussion of underlying assumptions). The GIS-based indicators were applied to urban districts of Baden-Württemberg, while national for Germany values of Deilmann et al. 2013 were applied to the rural districts.

\subsubsection{Uncertainties in the data}

Regarding the underlying data, we used best available datasets, tested it for different uncertainties and performed uncertainty analyses (e.g. with different demand prognosis for buildings or different vacancy and retrofit rates). A comparison of our model results to literature values is shown in Figure $19^{43}$ for RB. Also, comprehensive tests on the robustness of the model, e.g. with updated empirical study results or better data such as more detailed material composition indicators per building type and construction year, should be part of future research.

\footnotetext{
${ }^{42}$ There is a large share of other, non-heated NRB that is assumed in this study and also by other literature to mainly belong to commercial and warehouse buildings (Deilmann et al. 2014, Dirlich et al. 2011, Gruhler and Böhm 2011b).

${ }^{43}$ Literature values in the same range like Schebek et al. 2017 and Ortlepp et al. 2015a,b are not used for validation.
} 
However, data uncertainties still occur (see Figure 4 and sections 4.4.1, 4.4.2, 5.2 and 5.3). For example, for heated NRB, the effective area equals the gross internal area per floor and for unheated NRB the effective area equals the footprint of the buildings (Deilmann et al. 2013). This results in some minor uncertainty, as most unheated buildings are single-story buildings. Further uncertainty results from the undifferentiated category „other unheated NRBs". A comparison to other data (Deilmann et al. 2014, Dirlich et al. 2011, Gruhler und Böhm 2011b) suggests an assignment of the majority of the "other unheated NRB" to trading and storage buildings.

\subsubsection{Comparability and lack of model validation}

A major challenge is still the determination of parameters and reference units (e.g. specific material composition values per building type and construction period) in NRB and RB to calculate future construction, retrofitting and deconstruction activities (see also Schiller et al. 2017a, b), e.g. with 3D LOD2 data, cadastral data, census statistics, survey data, life expectancies of building elements and typologies (Naber et al. 2017).

Compared to Schiller et al. 2017a,b we connect material flows to stakeholder objectives and policies, integrate retrofit activities, broaden the focus from masonry and concrete recycling to 16 material categories (see Table 6), include road infrastructure and use a newer data base from 2015. Deilmann et al. 2014 analyse 16 building products, material recipes and renovation cycles, but do not consider changes in framework conditions, stakeholder objectives, technical infrastructure networks and a regional differentiation. Compared to Schiller et al. 2017a,b we consider RB, NRB and road infrastructure in the material flow analysis model part. But, due to the focus on RBs, NRBs and road infrastructure, the model neglects other network infrastructure like power plants, piping and wiring networks, dams, water ways or railways and other sectors that might have a high impact on resource demand and recycling material demand or supply. This should be investigated in future work as well. Further limitations of the model are that other sectors are missing and there is a restriction of demand and supply matching only within counties/districts.

But, models in literature often have different system boundaries and underlying data that hamper comparability between the models. And, parameter assumptions and uncertainties still remain. 
Validation of model results with measured values (e.g. material inventories, mass flows) is still an unsolved problem. It could be done in the next years by collecting real numbers, statistics and observations and comparing it with model projections - at least as long as basic model assumptions remain adequate.

\subsubsection{Physically limited circulation and replacement of materials}

Following German standards and regulation, the resource conservation potentials in circular economy are restricted to $25-32 \%$ of substitution of primary aggregates by secondary aggregates from processed C\&D waste in new concrete (see e.g. Schiller et al. 2017b, p. 683). And, about $30 \%$ of the new concrete requires primary cement anyway (ibid.). And, the model doesn't solve general problems discussed by Schiller et al. 2015 (p.180), of physically limited material circulation, problem shifting (e.g. demand for road work might remain and be satisfied by primary materials) and limited replacement of primary raw materials because of recycling losses. However, depending on the considered region, problem shifting might be less important due to stagnating road infrastructure development.

\subsection{Assumptions and caveats}

The proposed approach still faces data gaps and has to made many assumptions (e.g. like Schiller et al. 2017b, p. 684). In the following the main assumptions of the developed model are named, questioned and discussed separately. Sections 6.3.1 and 6.3.2 discuss assumptions on the basic MFA model based on literature (e.g. see Schiller et al. 2017b, p.684 for a discussion of uncertainties) and on the developed hybrid MFA approach for NRB, whereas sections 6.3.3 and 6.3.4 address the assumptions on the original contribution of the paper.

\subsubsection{NRB gross volume, age distribution and vacancy rate assumptions}

Main assumptions are the (1) transfer of the GIS-based analysis of commercially used gross volumes in RB and (2) the indicator-, statistics- and GIS-based derivation of NRB areas in the metropolis Hamburg to "urban", large to medium-sized cities in the case study region. Furthermore, we assume (3) similar age distributions and vacancy rates of multifamily RB and NRB. For NRBs, we used the distribution of 
construction periods of the existing multi-family houses as an approximation to the age structure of non-residential buildings. However, this represents a rough assumption and it results in deviations of the model results. The vacancy rate is approximated by the values for multifamily RB for 2011 (Zensus 2011). This is a simplification due to missing data. It is assumed that the multifamily RBs are more similar to NRB than single-family houses and that the development of the NRBs in a district is somehow linked to the RBs housing the employees working in NRBs. Also, uncertainties regarding the (4) local development of vacancy rates prevail because of the absence of data and the currently unspecific values (independent to the building type).

Furthermore, the (5) proportion of demand for non-residential space in residential buildings is uncertain. We assume that the difference of gross volume of Zensus 2011 data and analysed GIS data is the amount of non-residentially used areas/volume in RB. The calculations showed shares of commercially used gross volumes in RB of $9.8 \%$ for urban (Hamburg values) and $18 \%$ for rural (average Germany) areas. This assumption leads to an uncertainty in the model results. The values for rural districts were used from the literature, while for the urban districts they were estimated from the GISand census-based calculations for Hamburg.

\subsubsection{Retrofit, replacement and demolition rates and other material-related assumptions}

The material inventory stock is calculated independently of demand for new housing by the demand for living space and the forecast of vacancy development. Thus, we accept a less precise stock input, but with a remaining forecasted stock, the calculated output is less flawed.

Furthermore, retrofitting is considered uniformly by statistical retrofit rates of the total stock (e.g. by Deilmann et al. 2014, Schiller et al. 2015, 2017b or Hong et al. 2016). We assume that RBs and NRBs are retrofitted every 40 respectively 30 years based on Deilmann et al. (2014), but without further differentiation for single building elements or their differing life time expectancies. Uncertainties occur as retrofitting does not affect all building elements and materials in the considered timeframe due to differing life time expectancies of different building products (such as exterior walls versus technical equipment). This should be part of future research. Changes of use are not depicted as there is no data available. 
The material output is equally distributed on the construction periods according to their share in building stock. This induces some uncertainty as it does not take into account that buildings from certain construction periods such as postwar buildings are preferably demolished. An overestimation of material output from replacement and retrofit activities takes place under high new construction rates as this would reduce the average age of building stock as well as the replacement and retrofit rates. However, this cannot be expected in the case study area.

The linear reduction of replacement demand at a vacancy rate of $6 \%$ to a complete stop of replacement construction at $9 \%$ vacancy rate may vary depending on the region and conditions. Even with a vacancy rate of $9 \%$, there will still be residual replacement activities. And, it is uncertain at which level the vacancy rate and the replacement demand will come to a standstill. For RB, BBSR combined these factors in their new housing demand projection (BBSR, 2015a). However, it was not adopted due to the unclear calculation methodology. Instead, region-unspecific and time-constant quotas for replacement demand were used.

And, due to missing data in NRBs we use regression values for material composition indicators for earlier construction periods before 1979 (see also section 6.2.1) and assume that known material composition indicators from later period can be reckoned back.

\subsubsection{Stakeholder assumptions}

To model the stakeholders in the C\&D resource management system, we had to make the following assumptions: (1) Grouping of main stakeholders into four main groups captures main stakeholders and their interests adequately, (2) stakeholders' objectives can be represented and modelled by the balanced score card approach, and (3) mutual influences between stakeholders can be quantified by survey respondents. Future research could further differentiate between stakeholders such as different types of awarding authorities, planners or different construction, processing, reprocessing and recycling industries in the C\&D sector (e.g. according to respective construction material/product value chains). We model stakeholders' objectives by five categories of the balances score card. However, other modelling approaches, such as Multiple-Criteria Decision Analysis (MCDA) for the 
description of stakeholder objectives might be more suitable. And, it might be challenging to quantify mutual influences between stakeholders and the values might be changing when considering more or other stakeholder groups.

\subsubsection{Resource conservation and policy measure assumptions}

To model the resource conservation policy measures in the C\&D resource management system, we had to make the following assumptions: (1) the singular and combined/bundled measure impacts can be quantified by survey respondents, (2) the mutual influences between policy measures can be quantified, (3) the temporal course of measure impact (by category) can be determined, (4) all relevant resource conservation measures of the C\&S sector are considered with the considered 31 measures, and (5) a maximum of three resource conservation measures are applied at the same time.

Currently, we derive fundamental coefficients of measure evaluation from survey results of 88 responses of stakeholders in Germany, and the survey might not be representative as the population (C\&D stakeholders in BW or Germany) is not known. This could be improved by the performance of a representative survey and an update of the coefficients in the model. And, the chosen impact periods of measures into short-term, medium-term and long-term and potential aftereffects can be discussed. Furthermore, especially the relative, absolute and temporal course of single measures' resource conservation impacts' could be further investigated in the future. In particular, impacts of R\&D measures or disruptive innovations (e.g. in recycling technologies) can hardly be quantified or foreseen. Also, although we modelled reinforcing or hampering effects or timely developments of policy measures for resource efficiency in the C\&D sector, they haven't been studied thoroughly and should be subject to future research, data collection and analysis, e.g. similar to Lu and Tam (2013). The already aggregated 31 resource conservation measures that are considered here might not be comprehensive or not directly transferable to other case study areas.

Due to the model limitation to a maximum of three simultaneous measures per bundle, the results might be unrealistic or overlain by other effects that are not part of the model. Currently, the underlying values result from pairwise comparisons of single measures. However, the more resource 
conservation measures are in action, the more difficult is the quantification of the effect of a single measure. In future work, a coupling of further measures and an analysis of further hampering or unexpected effects and decisions are recommended. Also, additional resource conservation strategies and measures might be more effective, like a higher usage or area sharing of buildings (e.g. AirBnB in $\mathrm{RBs})$, individual actions, a reduced $\mathrm{m}^{2} /$ capita demand in $\mathrm{RB}$ or an increased building product/material life time that are not considered yet.

\section{Conclusions and outlook}

The results indicate that there is still need for more and better data on the building stock (especially of NRB) and integration of the non-road infrastructure to verify assumptions and reduce data uncertainty. Reliable data is missing and should be investigated for NRBs as well as (better) information about specific material composition values $\left[\mathrm{kg} / \mathrm{m}^{3}\right]$ (incl. hazardous materials), retrofitting status and rates, age distributions and vacancy rates in all building types. For Germany, urban mining and inventorying of building and infrastructure stock is increasing, but detailed figures on C\&D waste are only available on federal and state level (Hiete et al. 2011, p. 338; Destatis 2018a, p. 31ff and 155f.; Destatis 2016). Additionally, no guidelines and national standards for material stock assessment or extensive empirical surveys or databases are available (Naber et al. 2017). They could provide classifications and indicators to compare resource efficiency in buildings and infrastructures and ease future projections especially in countries with large stocks. Data availability of material stocks and flows of other infrastructure (e.g. power plants, piping and wiring networks, dams, water ways or railways) and other sectors and respective stakeholders have to be checked. Their integration into the is important for a comprehensive C\&D resource management.

Possibilities of GIS, automated cadastral information systems and remote sensing are under-utilized (Naber et al. 2017) and until now only focus on the urban level (Kleemann et al. 2016, Mastrucci et al. 2017). They would reduce the need for assumptions and approximations, but are often subject to data 
protection rights and not freely available for research (Naber et al. 2017). Thus, a stronger cooperation with mapping authorities for urban mining purposes is required (Schebek et al. 2017).

Also, current models are not comparable due to differing system boundaries, assumptions and data. The models lack validation both on national but in particular on regional level (Wu et al. 2014, Schiller et al. 2017b). Further validations, especially regarding the stakeholders as well as absolute and relative impacts and timely effects of policy measures, their interactions and mutual influence effects will have to be performed in future research.

On top of this, future analyses could extend the current material stock and flow reduction/balance approach by a focus on maximizing the capital value of material stock or maximizing the ecological benefit. Also, inter-sectoral analyses beyond the road infrastructure should be integrated to identify the full resource conservation potential, especially in regions with RC material surplus.

To reach climate and resource efficiency goals, also the locally/regionally optimized matching of C\&D waste supply and (recycled) construction material demand and $\mathrm{CO}_{2} \mathrm{e}$ reduction potentials by less transportation is crucial.

\section{Acknowledgements}

We gratefully acknowledge the financing from Baden-Württemberg Stiftung in the course of the research project StAR-Bau (funding acronym: NaBau6) that led to this publication. Furthermore, we thank Thomas Lützkendorf, Florian Knappe, Rebecca Werle, Jérémy Rimbon, Andreas Cordes, Olga Schamber, Andreas Müller, Mirea Meyer zu Rheda, Elias Naber and Simon Föll for their contributions to the project StAR-Bau and this publication. 


\section{Appendix A - Tables and Figures}

Table 15: Most important resource conservation measures for the C\&D sector in Baden-Württemberg, Germany (as a result of the two surveys, desk-based research and model results)

\begin{tabular}{|c|c|c|}
\hline Key measures & $\begin{array}{l}\text { Measure } \\
\text { categories }\end{array}$ & $\begin{array}{c}\text { Measure } \\
\text { effect }\end{array}$ \\
\hline \begin{tabular}{l|l|}
1 & $\begin{array}{l}\text { Adaption of courses and lectures (e.g. engineers, architects) and the offering of further } \\
\text { education for enhancing environmental awareness }\end{array}$
\end{tabular} & Informational & unspecific \\
\hline $\begin{array}{ll}2 & \begin{array}{l}\text { Establishment of an environmental economic accounting as a complement to the } \\
\text { national accounts }\end{array}\end{array}$ & Informational & unspecific \\
\hline $3 \begin{array}{l}\text { Establishment and communication of a material accounting system to create and } \\
\text { update a material "passport" or inventory or a material cadastre of buildings }\end{array}$ & Organizational & unspecific \\
\hline $4 \mid \begin{array}{l}\text { Preferred land allocation / construction permit for construction projects that are } \\
\text { predominantly made from recycled building materials }\end{array}$ & Legal & unspecific \\
\hline \begin{tabular}{|l|l} 
& $\begin{array}{l}\text { Oonsumer preference of resource-saving solutions in construction project tenders (for } \\
\text { example, by the state / public authorities) }\end{array}$
\end{tabular} & Informational & unspecific \\
\hline 6 Minimization of additional bureaucracy/regulation of recycled building materials & Organizational & unspecific \\
\hline 7 Promotion of "voluntary" product responsibility along the lifecycle by manufacturers & Organizational & unspecific \\
\hline $8 \begin{array}{l}\text { Introduction of a minimum quota for the use of recycled building materials in new } \\
\text { buildings, instead of or additionally to maximum limitation }\end{array}$ & Legal & specific \\
\hline 9 Introduction of a landfill ban on recyclable material & Legal & specific \\
\hline $10 \begin{array}{l}\text { Introduction of stricter waste management and recycling regulations, e.g. penalty } \\
\text { payments for improper disposal of building materials }\end{array}$ & Legal & unspecific \\
\hline 11 Increase of landfill fees & Financial & unspecific \\
\hline $\begin{array}{l}12 \text { Promotion of R\&D for recycling technology, new processes and machinery to recycle } \\
\text { materials (e.g. technical possibilities in plastics recycling) }\end{array}$ & $\begin{array}{l}\text { Research \& } \\
\text { development }\end{array}$ & unspecific \\
\hline \begin{tabular}{l|l}
13 & $\begin{array}{l}\text { Promotion of R\&D of new environmentally and recyclable building materials to replace } \\
\text { "non-recyclable" building materials }\end{array}$
\end{tabular} & $\begin{array}{l}\text { Research \& } \\
\text { development }\end{array}$ & unspecific \\
\hline $\begin{array}{l}14 \text { Promotion of R\&D of improved construction processes (resource savings through better } \\
\text { use of materials, or less offcuts / waste) }\end{array}$ & $\begin{array}{l}\text { Research \& } \\
\text { development }\end{array}$ & unspecific \\
\hline $15 \begin{array}{l}\text { Promotion of quality labels (awards) for recycling companies that meet quality } \\
\text { standards (more funds in respective associations and authorities) }\end{array}$ & Informational & unspecific \\
\hline $\begin{array}{l}16 \text { Promotion of the use of materials with high recyclability (for example, by issuing return } \\
\text { guarantees) }\end{array}$ & Informational & specific \\
\hline 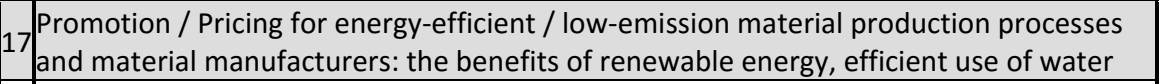 & Financial & unspecific \\
\hline $\begin{array}{l}18 \text { Promotion of selective dismantling through stipulations in sustainability assessment } \\
\text { systems or by requirements for public-sector projects }\end{array}$ & Informational & unspecific \\
\hline $19 \begin{array}{l}\text { Promotion of information and a positive image of sustainable construction (e.g. use of } \\
\text { recycled building materials) }\end{array}$ & Informational & unspecific \\
\hline $20 \begin{array}{l}\text { Encouraging collaborations along the construction value chain to reduce resource } \\
\text { consumption }\end{array}$ & Organizational & unspecific \\
\hline $\begin{array}{l}21 \text { lompotion of voluntary agreements / commitments for resource conservation between } \\
\text { companies as well as between companies and the state (setting of incentives for } \\
\text { companies to commit themselves to set and achieve resource conservation goals) }\end{array}$ & Organizational & unspecific \\
\hline 22 Introduction of new directives / laws on equality of recycled and primary materials & Legal & specific \\
\hline $23 \mid \begin{array}{l}\text { Promotion of information / transparency on waste prevention, introduction of stricter } \\
\text { waste management and recovery rules and environmental activities of companies }\end{array}$ & Informational & unspecific \\
\hline $24 \begin{array}{l}\text { New financial products / loans / subsidies for resource efficient construction (e.g. } \\
\text { recycling products are not considered as additional risk) }\end{array}$ & Financial & specific \\
\hline $25 \begin{array}{l}\text { More funds for remediation programs - new financial products / credits / subsidies to } \\
\text { promote and increase redevelopment rates }\end{array}$ & Financial & unspecific \\
\hline $\begin{array}{l}26 \text { Other prizes / awards for resource / environmentally-friendly construction projects } \\
\text { (such as the „Holzbaupreis") }\end{array}$ & Financial & unspecific \\
\hline $27 \begin{array}{l}\text { Promotion of the consideration of recycling / disposal concepts for used materials/ } \\
\text { products/ components during building design (Design for Deconstruction) }\end{array}$ & Organizational & unspecific \\
\hline $\begin{array}{l}288 \begin{array}{l}\text { Review of the planned German MantelV regulation on the suitability of the restrictions } \\
\text { and adaptation of the rules for RC materials use }\end{array} \\
\end{array}$ & Legal & unspecific \\
\hline $29 \begin{array}{l}\text { Promotion of eco-labels (such as "Blauer Engel") for better marketing of recycled } \\
\text { building materials }\end{array}$ & Informational & specific \\
\hline 30|Increased involvement of stakeholders in the planning of regulations / initiatives & Organizational & unspecific \\
\hline
\end{tabular}


Table 16: Groups of measures and their reference in literature

\begin{tabular}{|c|c|c|c|c|c|c|c|c|c|c|}
\hline Maßnahmengruppen & & & & & & & & & & Anzahl \\
\hline Anreizsysteme entwickeln & Sellier, 2005 & $\begin{array}{l}\text { Deutscher } \\
\text { Abbruchverband } \\
\text { e.V.. } 2007\end{array}$ & $\begin{array}{l}\text { Dechantsreiter et al. } \\
(2015)\end{array}$ & $\begin{array}{l}\text { Kohler und Hassler, } \\
\quad 1999\end{array}$ & Yuan et al, 2011 & & & & & 5 \\
\hline $\begin{array}{l}\text { Barrieren beim } \\
\text { ressourcenschonenden Handeln } \\
\text { abschaffen }\end{array}$ & $\begin{array}{l}\text { ZDB, 2015a; } \\
\text { ZDB, 2015b }\end{array}$ & $\begin{array}{l}\text { Deutscher } \\
\text { Abbruchverband } \\
\text { e.V., } 2007\end{array}$ & $\begin{array}{l}\text { Dechantsreiter et al. } \\
\quad(2015)\end{array}$ & & & & & & & 3 \\
\hline $\begin{array}{l}\text { Bauabläufe im Sinne der } \\
\text { Kreislaufwirtschaft gestalten }\end{array}$ & $\begin{array}{l}\text { Kohler und Hassler, } \\
1999\end{array}$ & & & & & & & & & 1 \\
\hline $\begin{array}{l}\text { Baumaterialien im Sinne des } \\
\text { Ressourcenschutzes herstellen }\end{array}$ & $\begin{array}{l}\text { BMVBS, 2013/ } \\
\text { BMVBS, 2011 }\end{array}$ & $\begin{array}{l}\text { Deutscher } \\
\text { Abbructwerband } \\
\text { e.V., } 2007\end{array}$ & Lehmann, 1999 & $\begin{array}{l}\text { Daxbeck et al., } \\
\quad 2011\end{array}$ & Kleine, 2009 & $\begin{array}{l}\text { Kohler und Hassler, } \\
1999\end{array}$ & & & & 6 \\
\hline Bauprozesse abfallarm gestalten & KrWG & $\begin{array}{l}\text { Deutscher } \\
\text { Abbruchverband } \\
\text { e.V., } 2007\end{array}$ & $\begin{array}{l}\text { BMVBS, 2013/ } \\
\text { BMVBS, 2012 }\end{array}$ & Arendt, 2000 & & & & & & 4 \\
\hline Bewusstsein schaften & Sellier, 2005 & Arendt, 2000 & $\begin{array}{l}\text { Lützkendorf und } \\
\text { Lorenz, } 2005\end{array}$ & BMUB, 2015 & Ascher, 2006 & $\begin{array}{l}\text { World sustainable } \\
\text { Building } \\
\text { Conferences, } 2014\end{array}$ & & & & 6 \\
\hline $\begin{array}{l}\text { Entwickeln der Recycling } \\
\text { unterstützenden Technik }\end{array}$ & $\begin{array}{l}\text { Porter und van der } \\
\text { Linde, } 1995\end{array}$ & $\begin{array}{l}\text { World sustainable } \\
\quad \text { Bulding } \\
\text { Conferences, } 2014\end{array}$ & & & & & & & & 2 \\
\hline $\begin{array}{l}\text { In die } \\
\text { kreislautwirtschattsorientierte } \\
\text { Forschung investieren }\end{array}$ & Knappe, 2012 & $\begin{array}{l}\text { Deutscher } \\
\text { Abbructwerband } \\
\text { e.V., } 2007\end{array}$ & $\begin{array}{l}\text { Daxbeck et al., } \\
\quad 2011\end{array}$ & Kleine, 2009 & Persson, 2009 & & & & & 5 \\
\hline Informationen verügbar machen & Arendt, 2000 & Curwell, 2003 & Ascher, 2006 & Scheiner, 2003 & & & & & & 4 \\
\hline $\begin{array}{l}\text { Instandhaltungsmaßnahmen } \\
\text { initilieren }\end{array}$ & $\begin{array}{l}\text { Kohler und Hassler, } \\
1999\end{array}$ & Kohler, 1999 & $\begin{array}{l}\text { Umweltbundesamt, } \\
2010\end{array}$ & $\begin{array}{l}\text { BMVBS, 2013/ } \\
\text { BMVBS, 2012 }\end{array}$ & & & & & & 4 \\
\hline $\begin{array}{l}\text { Interne Berechnungs- und } \\
\text { Planungsprozesse anpassen }\end{array}$ & Sellier, 2005 & Arendt, 2000 & & & & & & & & 2 \\
\hline Kooperationen entwickeln & Arendt, 2000 & Ortiz et al., 2009 & $\begin{array}{l}\text { World Sustainable } \\
\text { Builing } \\
\text { Conference, } 2014\end{array}$ & & & & & & & 3 \\
\hline $\begin{array}{l}\text { Kreislautwirtschaft gerechte } \\
\text { Abtallbehandlung gewährleisten }\end{array}$ & $\begin{array}{l}\text { Kohler und Hassler, } \\
1999\end{array}$ & BMVBS, 2013 & & & & & & & & 2 \\
\hline $\begin{array}{c}\text { Planung im Sinne des } \\
\text { Ressourcenschutzes gestalten }\end{array}$ & $\begin{array}{l}\text { BMVBS, 2013/ } \\
\text { BMVBS, } 2011\end{array}$ & Lehmann, 2002 & $\begin{array}{l}\text { Daxbeck et al., } \\
2011 \\
\text { Daxbeck et al., } \\
2010\end{array}$ & $\begin{array}{l}\text { Lütrkendorf und } \\
\text { Lorenz, } 2005\end{array}$ & Kohler, 1999 & $\begin{array}{l}\text { BMWi, 2014 Allianz } \\
\text { für rachhatige } \\
\text { Beschaftung }\end{array}$ & Persson, 2009 & Kern et al. , 2015 & Berner et al., 2015 Clement et al., 2010 & 10 \\
\hline Qualität der Bauten gewährleisten & $\begin{array}{l}\text { BMVBS, 2013/ } \\
\text { BMVBS, 2011 }\end{array}$ & Mora, 2007 & & & & & & & & 2 \\
\hline $\begin{array}{l}\text { Qualität der RC-Baustoffe } \\
\text { gewährleisten }\end{array}$ & $\begin{array}{l}\text { Daxbeck et al., } \\
2011\end{array}$ & Mora, 2007 & & & & & & & & 2 \\
\hline $\begin{array}{c}\text { Ressourcenschonende } \\
\text { Verwendung der Baumaterialien }\end{array}$ & $\begin{array}{l}\text { Daxbeck et al., } \\
2011\end{array}$ & ZDB, 2015 & ZDB, 2015 & Persson, 2009 & Knappe 2008, UBA & $\begin{array}{l}\text { Umweltbundesamt, } \\
2010\end{array}$ & & & & 6 \\
\hline Strafsysteme entwickeln & Sellier, 2005 & $\begin{array}{l}\text { Daxbeck et al., } \\
\quad 2011\end{array}$ & $\begin{array}{l}\text { Kohler und Hassler, } \\
\quad 1999\end{array}$ & & & & & & & 3 \\
\hline $\begin{array}{l}\text { Vermarktung//mage der RC- } \\
\text { Baustoffe verbessern }\end{array}$ & Kohler, 1999 & $\begin{array}{l}\text { Deutscher } \\
\text { Abbruchverband } \\
\text { e.V., 2007 }\end{array}$ & & & & & & & & 2 \\
\hline $\begin{array}{l}\text { Vorbildcharakter des Staates } \\
\text { gewährleisten }\end{array}$ & Sellier, 2005 & Kohler, 1999 & $\begin{array}{l}\text { Enquête- } \\
\text { Kommission, } 1994\end{array}$ & & & & & & & 3 \\
\hline Vorschriften ausbauen & Clement et al., 2010 & $\begin{array}{l}\text { Deutscher } \\
\text { Abbruchiverband } \\
\text { e.V., } 2007\end{array}$ & ZDB, 2015 & KrWG & Arendt, 2000 & $\begin{array}{l}\text { Kohler und Hassler, } \\
1999\end{array}$ & $\begin{array}{l}\text { BMVBS, } 2013 \\
\text { BMVBS, } 2011\end{array}$ & $\begin{array}{l}\text { Daxbeck et al. } \\
\text { 2010; Daxbeck et } \\
\text { al. } 2011\end{array}$ & $\begin{array}{l}\text { Enquête- } \\
\text { Kommission, } 1994\end{array}$ & 9 \\
\hline
\end{tabular}

Table 17: Material-specific impact measured in survey of material-specific measures (range: 1 to 5, $5=$ high impact of measure on material flow)

\begin{tabular}{|c|c|c|c|}
\hline \multirow[t]{2}{*}{ Material-specific measures } & \multicolumn{3}{|c|}{ Material-specific measure impact on material flows } \\
\hline & Metals & Minerals & $\begin{array}{l}\text { Organic } \\
\text { materials }\end{array}$ \\
\hline $\begin{array}{l}\text { (8) Introduction of a minimum quota for the use of recycled } \\
\text { building materials in new buildings, instead of or additionally to } \\
\text { maximum limitation }\end{array}$ & 3.33 & 4.33 & 3.33 \\
\hline (9) Introduction of a landfill ban on recyclable material & 3.30 & 3.50 & 3.20 \\
\hline $\begin{array}{l}\text { (16) Promotion of the use of materials with high recyclability (for } \\
\text { example, by issuing return guarantees) }\end{array}$ & 3.19 & 3.44 & 3.13 \\
\hline $\begin{array}{l}\text { (22) Introduction of new directives / laws on equality of recycled } \\
\text { and primary materials }\end{array}$ & 3.20 & 3.53 & 3.13 \\
\hline $\begin{array}{l}\text { (24) New financial products / loans / subsidies for resource } \\
\text { efficient construction (e.g. recycling products are not considered } \\
\text { as additional risk) }\end{array}$ & 2.83 & 3.08 & 2.67 \\
\hline $\begin{array}{l}\text { (29) Promotion of eco-labels (such as "Blauer Engel") for better } \\
\text { marketing of recycled building materials }\end{array}$ & 3.29 & 3.29 & 3.14 \\
\hline
\end{tabular}




\begin{tabular}{|ccccc|}
\hline Measure & $\varnothing$ Willingsness to cooperate \\
{$[\%]$} & $\begin{array}{c}\text { Stakeholder with the } \\
\text { lowest willingsness to } \\
\text { cooperate }\end{array}$ & Executive Stakeholder & $\begin{array}{c}\text { Effectivity of the } \\
\text { measure } \%\end{array}$ \\
\hline $\begin{array}{c}\text { implementation of incentive } \\
\text { systems }\end{array}$ & 40,71 & $\begin{array}{c}\text { Planner / Construction } \\
\text { Company }\end{array}$ & Public Authorities & 59,89 \\
\hline
\end{tabular}

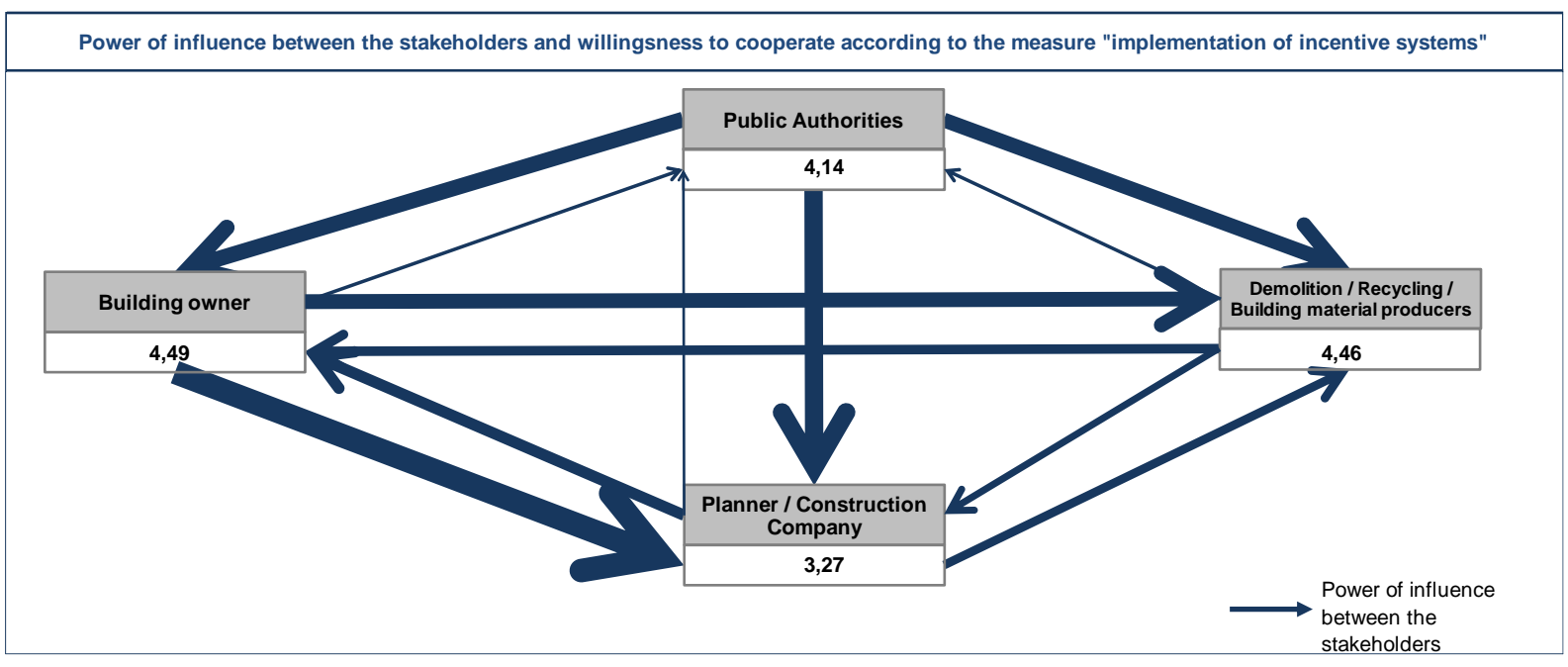

Figure 17: Influence diagram for measure "implementation of incentive systems" between the four considered stakeholder groups and willingness to act according to the measure ( $5=$ maximum willingness to act, $1=$ minimum willingness to act). The broader the arrow, the larger the influence between the stakeholders.

Description of Figure 17: In the model, policy measures can be selected and the respective influence diagram between stakeholders can be mapped. Figure 17 shows the measure "implementation of incentive systems" where public authorities are the executive stakeholder in the system and all stakeholders assign an effectivity of the measure(s) of $59.89 \%$ and a resource saving impact of $73.33 \%$. In Figure 17, the arcs represent the influence $E_{i j}$ of a stakeholder $i$ on another stakeholder $j$. The higher the influence, the larger is the arc. As arcs are directed in two directions, they represent mutual influences between stakeholders. Furthermore, the numbers associated to the stakeholders indicate their isolated willingness to act according to the selected policy measure (without the influence of other stakeholders). The stakeholders with the lowest willingness to cooperate are planners and construction companies, as their benefit in their respective objective functions is the lowest. 


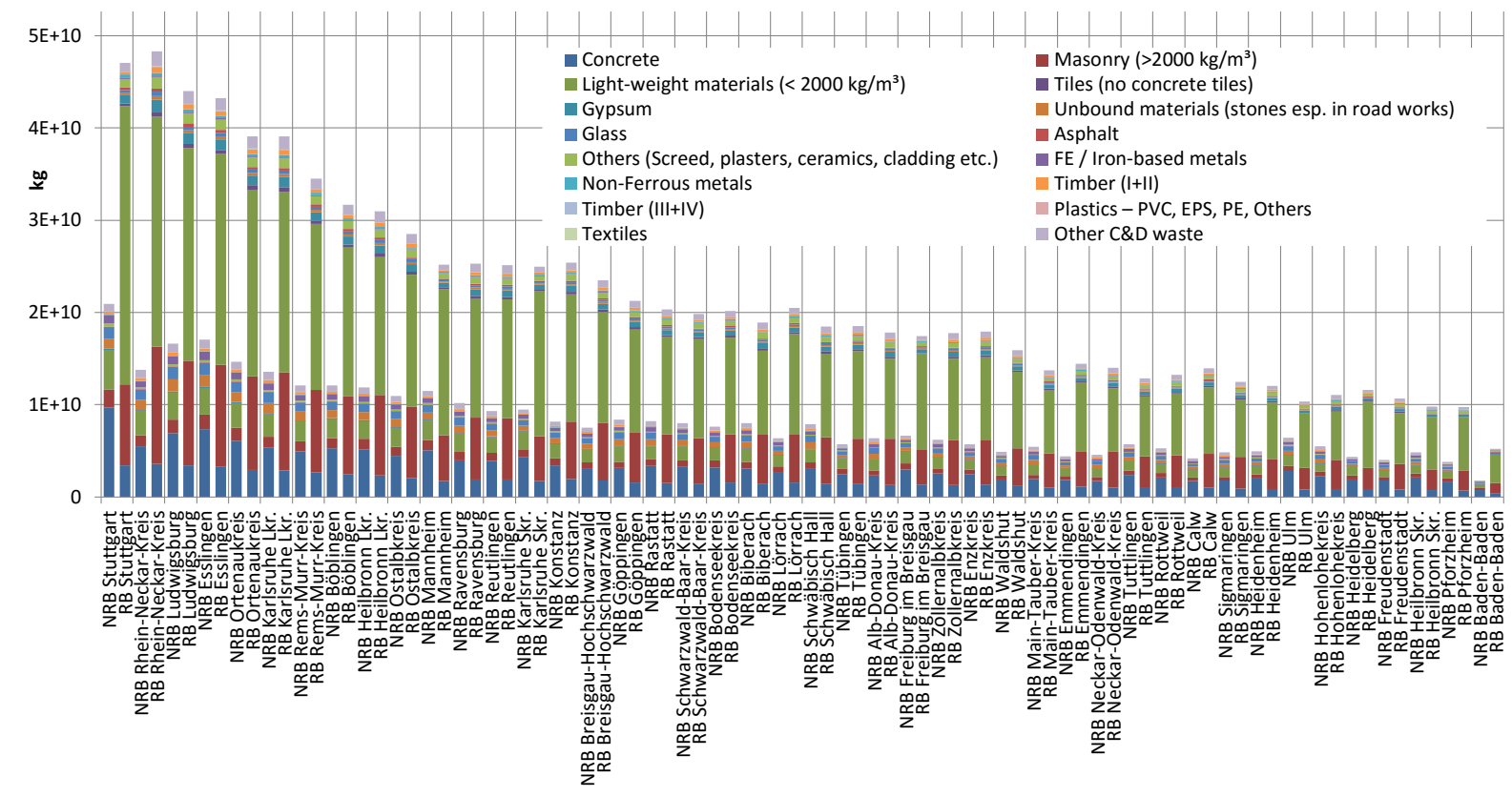

Figure 18: Building stock in RB and NRB in Baden-Württemberg in 2016 (standard scenario), differentiated according to materials 


\begin{tabular}{|c|c|c|c|}
\hline $\begin{array}{l}\text { Residential buildings } \\
\text { Baden-Württemberg --> } \\
\text { relative change in stock; } \\
\text { Standard = } 100 \%\end{array}$ & $\begin{array}{l}\text { Stock [number of } \\
\text { buildings] (values and } \\
\text { characteristics based on } \\
\text { Gruhler \& Böhm 2011 }\end{array}$ & $\begin{array}{l}\text { Stock [number of } \\
\text { buildings] (values and } \\
\text { characteristics based on } \\
\text { IWU) }\end{array}$ & $\begin{array}{l}\text { Stock of residential } \\
\text { area (without non- } \\
\text { residential areas in RB) } \\
\text { (own values) }\end{array}$ \\
\hline Stuttgart & $97 \%$ & $122 \%$ & $91 \%$ \\
\hline Böblingen & $95 \%$ & $108 \%$ & $91 \%$ \\
\hline Esslingen & $103 \%$ & $118 \%$ & $91 \%$ \\
\hline Göppingen & $101 \%$ & $107 \%$ & $90 \%$ \\
\hline Ludwigsburg & $100 \%$ & $117 \%$ & $91 \%$ \\
\hline Rems-Murr-Kreis & $105 \%$ & $122 \%$ & $92 \%$ \\
\hline Heilbronn & $102 \%$ & $127 \%$ & $90 \%$ \\
\hline Heilbronn & $92 \%$ & $91 \%$ & $84 \%$ \\
\hline Hohenlohekreis & $83 \%$ & $83 \%$ & $78 \%$ \\
\hline Schwäbisch Hall & $87 \%$ & $88 \%$ & $80 \%$ \\
\hline Main-Tauber-Kreis & $87 \%$ & $87 \%$ & $81 \%$ \\
\hline Heidenheim & $93 \%$ & $93 \%$ & $83 \%$ \\
\hline Ostalbkreis & $91 \%$ & $92 \%$ & $84 \%$ \\
\hline Baden-Baden & $98 \%$ & $109 \%$ & $93 \%$ \\
\hline Karlsruhe & $86 \%$ & $106 \%$ & $92 \%$ \\
\hline Karlsruhe & $98 \%$ & $103 \%$ & $92 \%$ \\
\hline Rastatt & $97 \%$ & $105 \%$ & $91 \%$ \\
\hline Heidelberg & $93 \%$ & $111 \%$ & $93 \%$ \\
\hline Mannheim & $87 \%$ & $111 \%$ & $91 \%$ \\
\hline Neckar-Odenwald-Kreis & $90 \%$ & $87 \%$ & $85 \%$ \\
\hline Rhein-Neckar-Kreis & $100 \%$ & $109 \%$ & $93 \%$ \\
\hline Pforzheim & $91 \%$ & $117 \%$ & $92 \%$ \\
\hline Calw & $99 \%$ & $103 \%$ & $88 \%$ \\
\hline Enzkreis & $97 \%$ & $96 \%$ & $87 \%$ \\
\hline Freudenstadt & $98 \%$ & $103 \%$ & $86 \%$ \\
\hline Freiburg im Breisgau & $85 \%$ & $111 \%$ & $92 \%$ \\
\hline Breisgau-Hochschwarzwald & $94 \%$ & $103 \%$ & $86 \%$ \\
\hline Emmendingen & $95 \%$ & $105 \%$ & $87 \%$ \\
\hline Ortenaukreis & $90 \%$ & $97 \%$ & $84 \%$ \\
\hline Rottweil & $93 \%$ & $94 \%$ & $83 \%$ \\
\hline Schwarzwald-Baar-Kreis & $90 \%$ & $99 \%$ & $83 \%$ \\
\hline Tuttlingen & $91 \%$ & $90 \%$ & $82 \%$ \\
\hline Konstanz & $91 \%$ & $104 \%$ & $86 \%$ \\
\hline Lörrach & $91 \%$ & $99 \%$ & $87 \%$ \\
\hline Waldshut & $91 \%$ & $96 \%$ & $86 \%$ \\
\hline Reutlingen & $95 \%$ & $97 \%$ & $85 \%$ \\
\hline Tübingen & $95 \%$ & $101 \%$ & $88 \%$ \\
\hline Zollernalbkreis & $97 \%$ & $93 \%$ & $85 \%$ \\
\hline Ulm & $90 \%$ & $103 \%$ & $87 \%$ \\
\hline Alb-Donau-Kreis & $90 \%$ & $89 \%$ & $83 \%$ \\
\hline Biberach & $86 \%$ & $83 \%$ & $80 \%$ \\
\hline Bodenseekreis & $93 \%$ & $107 \%$ & $84 \%$ \\
\hline Ravensburg & $89 \%$ & $93 \%$ & $82 \%$ \\
\hline Sigmaringen & $89 \%$ & $86 \%$ & $82 \%$ \\
\hline
\end{tabular}

Figure 19: Relative model result validation of residential building stock of the case study region in 2016 with other existing approaches (standard value of the material flow model $=100 \%$ ) 


\section{Appendix B - Survey}

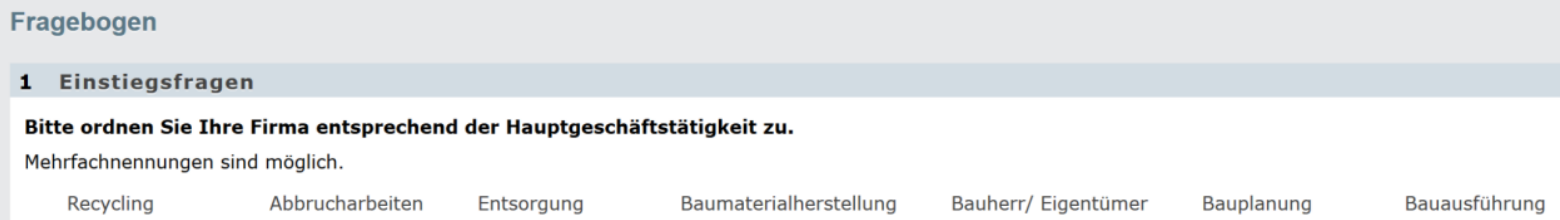

Wie wichtig sind folgende Faktoren für den Erfolg Ihres Unternehmens?

nicht wichtig weniger wichtig neutral wichtig sehr wichtig

Faktor Umwelt

Umweltschonendes Handeln

Verbesserung des Allgemeinwohls

\section{Faktor Finanzen}

Materialkosten

Personalkosten

Produktionskosten/ Baukosten

Profitabilität der Leistungen

\section{Faktor Kunde}

Image der Firma

Kundenbeziehung

Kundenzufriedenheit

Qualität der erbrachten Leistungen

\section{Faktor Prozesse}

Prozesse

Innovation

Spezialisierung

Technische Exzellenz

Interaktion mit anderen Akteuren

Differenzierung von der Konkurrenz

Faktor Mitarbeiter und Entwicklung

Bildung

Produktivität

Vorhandene Technik 
3 Hauptteil2

Bitte schätzen Sie, in wie weit die folgenden Akteure den Ressourcenverbrauch über den gesamten Lebenszyklus eines Bauwerkes beeinflussen. $\begin{array}{llll}\text { sehr schwach schwach neutral stark stark } & \end{array}$

Recyclingunternehmen

Abbruchunternehmen

Entsorgungsunternehmen

Baumaterialhersteller

Planer

Bauausführende Unternehmen

Bauherr/ Eigentümer

Öffentliche Hand

Medien

Bitte bewerten Sie den Einfluss Ihrer Firma auf die Geschäftstätigkeit folgender Akteure.

$\begin{array}{llll}\text { sehr schwach schwach neutral stark } & \text { sehr stark }\end{array}$

Recyclingunternehmen

Abbruchunternehmen

Entsorgungsunternehmen

Baumaterialhersteller

Planer

Bauausführende Unternehmen

Bauherr/ Eigentümer

Öffentliche Hand

Medien

Bitte bewerten Sie, wie stark folgende Akteure die Geschäftstätigkeit Ihrer Firma beeinflussen.

sehr schwach schwach neutral stark

sehr stark

Recyclingunternehmen

Abbruchunternehmen

Entsorgungsunternehmen

Baumaterialhersteller

Planer

Bauausführende Unternehmen

Bauherr/ Eigentümer

Öffentliche Hand

Medien

\section{Wichtigste Maßnahmen}

Bitte bewerten Sie das Potential folgender Maßnahmen, die Verwendung von Primärrohstoffen zu reduzieren.

neutral

sehr schwach

schwach

stark

sehr stark

Finanzielle Maßnahmen

Neue Finanzprodukte/Kredite

Subventionen für ressourcenschonendes

Bauen (z.B. Nutzung von

Recyclingbaustoffen)

Neue Finanzprodukte/Kredite

/Subventionen zur Förderung von

Sanierungen

Preise für ressourcen-/umweltschonende

Bauprojekte

Erhöhung von Deponiegebühren (um

Recycling attraktiver zu machen)

Zusatzkosten/Steuern auf Kauf von

Primärrohstoffen

Förderung/Preise für

energieeffiziente/schadstoffarme

Materialherstellungsverfahren und

Materialhersteller: (Nutzen erneuerbarer

Energie, effiziente Nutzung von Wasser) 


\section{Forschung \& Entwicklungs Maßnahmen}

Förderung der Forschung u. Entwicklung für Recyclingtechnik

Förderung der Forschung u. Entwicklung zur Verbesserung von Bauprozessen

Förderung der Forschung u. Entwicklung von Substituten für nicht recyclebare Baumaterialien

\section{Informatorische Maßnahmen}

Förderung und Forderung des Selektiven

Rückbaus

Förderung der Herstellung und

Verwendung von Materialien mit hoher

Recyclingfähigkeit

Förderung nachhaltigkeit

Materialbeschaffung (z.B. Carbon

Footprint Deutscher Stahl vs. Chinesischer

Stahl)

Anpassung von Lehrinhalten (z.B.

Ingenieure, Architekten) oder das

Anbieten von Weiterbildungen zur

Förderung des Umweltbewusstseins

Förderung der Informationsverfügbarkeit und des Images des nachhaltigen Bauens (z.B. Einsatz von Recyclingbaustoffen)

Aufbau einer umweltökonomischen

Gesamtrechnung als Komplement zur

volkswirtschaftlichen Gesamtrechnung

In Bauprojekt-Ausschreibungen (z.B. vom

Staat) sollen ressourcenschonende

Lösungen bevorzugt werden

Förderung der Gütesiegelvergabe für

Recycling-Betriebe, die Qualitätsstandards

erfüllen

Verbessertes Eco-Labeling zur besseren

Vermarktung von Recyclingbaustoffen

(Abschaffen der Wahrnehmung "öko" = teuer)

\section{Organisatorische Maßnahmen}

Bürokratie zur Verwendung von

Recyclingbaustoffen minimieren

Förderung der

Informationsverfügbarkeit/Transparenz

über Abfallvermeidung, Einführung

strengerer Abfallbehandlungs- und

Verwertungsvorschriften,

Umweltaktivitäten von Unternehmen

Aufbau und Kommunikation eines betrieblichen Stoffbuchhaltungssystems

Förderung freiwilliger

Abkommen/Selbstverpflichtungen im

Sinne des Ressourcenschutz zwischen

Unternehmen und Unternehmen und

Staat

Förderung von Kooperationen entlang der

Wertschöpfungskette-Bau zur

Reduzierung des Ressourcenverbrauchs

Bereits während der Gebäudeplanung

mögliche Recycling-/Entsorgungskonzepte

für eingesetzte Materialien/Bauteile

berücksichtigen

Verstärkte Einbeziehung von Akteuren be

der Planung von Vorschriften/Initativen

Einführung einer klaren

Verantwortungszuordnung/Haftung für

Bauteile/Baustoffe entlang des Bauzyklus 


\section{Rechtliche Maßnahmen}

Bevorzugte Landvergabe/Bauerlaubnis an Bauvorhaben mit großem Anteil an Recyclingbaustoffen

Einführung strengerer Abfallbehandlungsund Verwertungsvorschriften (z.B.

Strafzahlungen für nicht sachgemäße

Entsorgung von Baustoffen)

Gleichstellung von Recycling- und Primärbaustoffen

Überprüfung der Mantelverordnung hinsichtlich der Zweckmäßigkeit der Restriktionen und Anpassung der

Vorschriften für die Verwendung der RCMaterialien

Einführung eines Deponieverbots für recyclingfähiges Material

Einführung einer Mindestquote für den

Einsatz von Recyclingbaustoffen bei

Neubauten, statt maximaler Begrenzung

Vermeidung von Abfall, Lärm, Staub

während der Materialherstellungs-, Bau-,

Instandhaltungs- und Abbruchsprozessen

\section{Einfluss von den wichtigsten Maßnahmen}

Bitte bewerten Sie das Potential folgender Maßnahmen, die Verwendung bestimmter Primärrohstoffen zu reduzieren.

Primärrohstoffe:

- Mineralische Stoffe: Beton, Mauerwerk $\left(>2 t / \mathrm{m}^{3}\right)$, Leichtbaustoffe $\left(<2 \mathrm{t} / \mathrm{m}^{3}\right)$, Dachziegel, Asphalt, Glas, Gips, unbebundene Materialen, Sonstiges

- Metalle: Eisen, Nicht-Eisen-Metalle

- Organische Stoffe: Holz (I + II), Holz (III + IV), Kunststoffe, Textilien

- Schadstoffe: KMF, Asbest, PCB, PAK

Wie stark verringert sich die Verwendung von Primärrohstoffen durch die Maßnahme:

"Neue Finanzprodukte/Kredite/Subventionen für ressourcenschonendes Bauen (z.B. Nutzung von Recyclingbaustoffen)"

verringert sich verringert sich verringert sich verringert sich verringert sich

Metalle

mineralische Stoffe

organische Stoffe

Wie stark verringert sich die Verwendung von Primärrohstoffen durch die Maßnahme:

"Gleichstellung von Recycling- und Primärbaustoffen, die die Verwendung von den unten aufgeführten Primärrohstoffen senken würde."

$\begin{array}{ccccc}\begin{array}{c}\text { verringert sich } \\ \text { nicht }\end{array} & \begin{array}{c}\text { verringert sich } \\ \text { sehr schwach }\end{array} & \begin{array}{c}\text { verringert sich } \\ \text { schwach }\end{array} & \begin{array}{c}\text { verringert sich } \\ \text { stark }\end{array} & \begin{array}{c}\text { verringert sich } \\ \text { sehr stark }\end{array}\end{array}$

Metalle

mineralische Stoffe

organische Stoffe

Wie stark verringert sich die Verwendung von Primärrohstoffen durch die Maßnahme:

"Förderung der Herstellung und Verwendung von Materialien mit hoher Recyclingfähigkeit

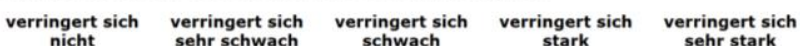

Metalle

mineralische Stoffe

organische Stoffe

Wie stark verringert sich die Verwendung von Primärrohstoffen durch die Maßnahme:

"Verbessertes Eco-Labeling zur besseren Vermarktung von Recyclingbaustoffen (Abschaffen der Wahrnehmung "öko" = teuer)"

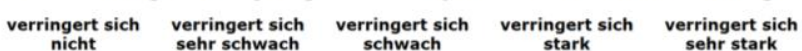

Metalle

mineralische Stoffe

organische Stoffe 
Wie stark verringert sich die Verwendung von Primärrohstoffen durch die Maßnahme:

"Einführung einer Mindestquote für den Einsatz von Recyclingbaustoffen bei Neubauten, statt maximaler Begrenzung"

$$
\begin{array}{ccccc}
\begin{array}{c}
\text { verringert sich } \\
\text { nicht }
\end{array} & \begin{array}{c}
\text { verringert sich } \\
\text { sehr schwach }
\end{array} & \begin{array}{c}
\text { verringert sich } \\
\text { schwach }
\end{array} & \begin{array}{c}
\text { verringert sich } \\
\text { stark }
\end{array} & \begin{array}{c}
\text { verringert sich } \\
\text { sehr stark }
\end{array}
\end{array}
$$

Metalle

mineralische Stoffe

organische Stoffe

\section{Interdependenzen $8 \mathrm{Maßnahmen}$}

Wie bewerten Sie das Zusammenspiel zweier Maßnahmen hinsichtlich einer verstärkenden bzw. abschwächenden Wirkung.

Betrachten Sie, dass die Reihenfolge innerhalb der Bündelung irrelevant ist. Es macht somit keinen Unterschied, wie MaBnahme A auf Maßnahme B oder anders herum wirkt.

Die Maßnahme "\#c_00o8\#"

wirkt in Verbindung mit den folgenden Maßnahmen:

stark
bschwăchend abschwächend neutral verstärkend verstarkend

\#c_0007\#

$\#$ \#_0006\#

\#c_0005\#

\#c_0004\#

\#c_0003\#

\#c_0002\#

\#c_0001\#

\section{Interdependenzen 7 Maßnahmen}

Wie bewerten Sie das Zusammenspiel zweier Maßnahmen hinsichtlich einer verstärkenden bzw. abschwächenden Wirkung.

Betrachten Sie, dass die Reihenfolge innerhalb der Bündelung irrelevant ist. Es macht somit keinen Unterschied, wie MaBnahme A auf MaBnahme B oder anders herum wirkt.

Die Maßnahme: "\#c_0007\#"

wirkt in Verbindung mit den folgenden Maßnahmen:

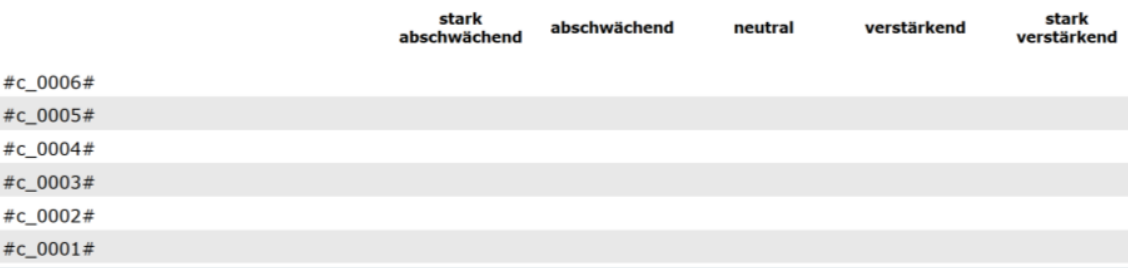

8 Interdependenzen 6 Maßnahmen

Wie bewerten Sie das Zusammenspiel zweier Maßnahmen hinsichtlich einer verstärkenden bzw. abschwächenden Wirkung.

Betrachten Sie, dass die Reihenfolge innerhalb der Bündelung irrelevant ist. Es macht somit keinen Unterschied, wie Maßnahme A auf MaBnahme B oder anders herum wirkt.

Die Maßnahme: "\#c_0006\#"

wirkt in Verbindung mit den folgenden Maßnahmen:

stark
abschwächend abschwächend neutral verstärkend

\section{Interdependenzen 5 Maßnahmen}

Wie bewerten Sie das Zusammenspiel zweier Maßnahmen hinsichtlich einer verstärkenden bzw. abschwächenden Wirkung.

Betrachten Sie, dass die Reihenfolge innerhalb der Bündelung irrelevant ist. Es macht somit keinen Unterschied, wie Maßnahme A auf MaBnahme B oder anders herum wirkt.

Die Maßnahme: "\#c_0005\#"

wirkt in Verbindung mit den folgenden Maßnahmen:

\#c_0004\#
\#c_0003\#
\#c_0002\#
\#c_0001\#


10 Interdependenzen $4 \mathrm{Maßnahmen}$

Wie bewerten Sie das Zusammenspiel zweier Maßnahmen hinsichtlich einer verstärkenden bzw. abschwächenden Wirkung.

Betrachten Sie, dass die Reihenfolge innerhalb der Bündelung irrelevant ist. Es macht somit keinen Unterschied, wie MaBnahme A auf Maßnahme B oder anders herum wirkt.

Die Maßnahme: "\#c_0004\#"

wirkt in Verbindung mit den folgenden Maßnahmen:

$$
\begin{gathered}
\text { stark } \\
\text { abschwächend abschwächend neutral verstärkend } \quad \begin{array}{c}
\text { stark } \\
\text { verstärkend }
\end{array}
\end{gathered}
$$

\#c_0003\#

\#c_0002\#

\#c_0001\#

11 Interdependenzen 3 Maßnahmen

Wie bewerten Sie das Zusammenspiel zweier Maßnahmen hinsichtlich einer verstärkenden bzw. abschwächenden Wirkung.

Betrachten Sie, dass die Reihenfolge innerhalb der Bündelung irrelevant ist. Es macht somit keinen Unterschied, wie MaBnahme A auf MaBnahme B oder anders herum wirkt.

Die Maßnahme: "\#c_0003\#"

wirkt in Verbindung mit den folgenden Maßnahmen:

stark
abschwăchend abschwächend

12 Interdependenzen 2 Maßnahmen

Wie bewerten Sie das Zusammenspiel zweier Maßnahmen hinsichtlich einer verstärkenden bzw. abschwächenden Wirkung

Betrachten Sie, dass die Reihenfolge innerhalb der Bündelung irrelevant ist. Es macht somit keinen Unterschied, wie MaBnahme A auf MaBnahme B oder anders herum wirkt.

Die Maßnahme: "\#c_0002\#"

wirkt in Verbindung mit den folgenden Maßnahmen:

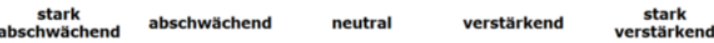

\#c_0001\#

13 Endseite

Vielen Dank für die Teilnahme an unserer Umfrage!

Mehr Informationen zum aktuellen Forschungsprojekt erhalten Sie unter http://www.lip.kit.edu/773_2778.php

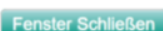

Figure 20: Structured stakeholder survey (in German) 


\section{Appendix C - Variable definitions}

Material flows are defined in the model by their material mat $\in M A T$, their application ber $\in B E R$ and their year of occurrence $j \in J$. Every material flow has a baseline value $S_{b e r, m a t, j}^{b}$ (without stakeholder and measure consideration) and a transformation value $S_{M_{d}, b e r, m a t, j}^{t}$ that depends on the simulated/performed measures $M_{d} \subseteq M$ (M= set of all possible measures). Every material mat $\in$ MAT belongs to exactly one material group $g \in G$ an. Accordingly, the following set definitions and relations apply:

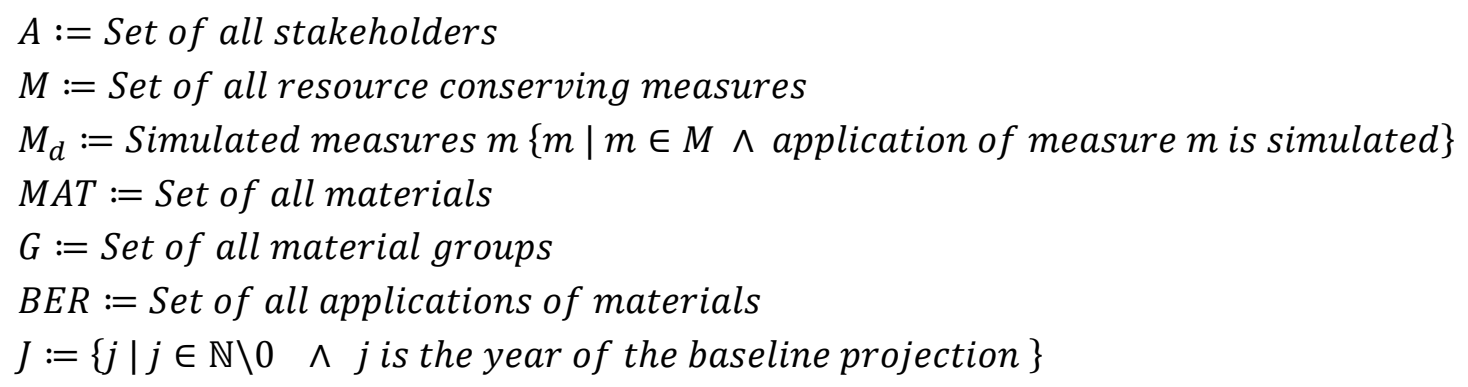

The bijective function $f$ describes the relation of materials to their superordinate material groups. So it follows that $\{$ concrete $\} \in M A T$ and $\{$ minerals $\} \in G$. Function $f$ defines that $\{$ concrete $\} \in$ $\{$ minerals\}.

$$
\begin{aligned}
f: M A T \rightarrow G, \text { mat } & \mapsto f(\text { mat }):=i, \text { mat } \in G_{f(\text { mat })} \\
& G_{i} \cap G_{j}=\emptyset
\end{aligned}
$$

Start and ending of the base projection horizon are set to the first and last year of set $J$ and the duration of the projection is calculated with:

$$
\begin{gathered}
\text { start }:=\min _{j \in J} j \\
\text { end }:=\max _{j \in J} j \\
\text { duration }:=|J|
\end{gathered}
$$

The specific application period $J_{m}$ of a measure $m$ defines to a large extent the effect on resource conservation. Start $_{m}$ denominates the beginning of the measure application and $e n d_{m}$ respectively the end, so that:

$$
\begin{aligned}
J_{m} & \subseteq J \\
\text { start }_{m} & =\min _{j \in J_{m}} j
\end{aligned}
$$




$$
\begin{gathered}
\text { end }_{m}=\max _{j \in J_{m}} j \\
\text { start } \leq \text { start }_{m} \leq \text { end }_{m} \leq \text { end }
\end{gathered}
$$

Furthermore, we define $J_{t} \neq J \neq J_{m}$ with a different application period of measure $t$. For $J_{t}$, the same relations apply like for $J_{m}$. The considered material flows are balances per year, based on the material inputs and outputs of the baseline projection:

$$
S_{b e r, m a t, j}^{b}=I N P U T_{b e r, m a t, j}^{b}-O U T P U T_{b e r, m a t, j}^{b}
$$

$\boldsymbol{S}_{\text {ber }, \text { mat }, j}^{\boldsymbol{b}}=$ Balance of material mat in application area ber in year $j$

$I_{\text {INPUT }}^{\boldsymbol{b}} \boldsymbol{b e r , \boldsymbol { m a t } , \boldsymbol { j }}=$ Input of materials mat into application area ber of the building and infrastructure stock in year $j$ OUTPUT $_{\text {ber,mat }, j}^{\boldsymbol{b}}=$ Output of material mat from application area ber of the building and infrastructure stock in year $j$ 


\section{References}

Abarca-Guerrero, L., Maas, G., van Twillert, H. (2017): Barriers and Motivations for Construction Waste Reduction Practices in Costa Rica, Resources 2017, 6(4), 69; https://doi.org/10.3390/resources6040069

Abdelhamid, M.S. (2014): Assessment of different construction and demolition waste management approaches, HBRC Journal, Volume 10, Issue 3, December 2014, Pages 317-326, https://doi.org/10.1016/j.hbrcj.2014.01.003

Ajayi, S. O. and Oyedele, L.O. (2017): Policy imperatives for diverting construction waste from landfill: Experts' recommendations for UK policy expansion, Journal of Cleaner Production, Volume 147, 20 March 2017, Pages 57-65, https://doi.org/10.1016/j.jclepro.2017.01.075

Augiseau, V. and Barles, S. (2017): Studying construction materials flows and stock: A review, Resources, Conservation and Recycling 123 (2017), 153-164, https://doi.org/10.1016/j.resconrec.2016.09.002

Banias, G., Achillas, C., Vlachokostas, C., Moussiopoulos, N., Papaioannou, I., (2011). A web-based Decision Support System for the optimal management of construction and demolition waste. Waste Manag. 31, 2497-2502. http://dx.doi.org/10.1016/j.wasman.2011.07.018.

Banse, J.; Effenberger, K.-H. (2006): Deutschland 2050 - Auswirkungen des demographischen Wandels auf den Wohnungsbestand / Germany 2050 - Effects of demographioc change on residential building stock. Leibniz-Institut für ökologische Raumentwicklung e.V. (IÖR). In: IÖR-Texte 152. Dresden.

Barles, S. (2009): Urban metabolism of Paris and its region. J. Ind. Ecol. 13 (6), 898-913, https://doi.org/10.1111/j.1530-9290.2009.00169.x.

Barles, S. (2014): L'écologie territoriale et les enjeux de la dématérialisation des sociétés: I'apport de l'analyse des flux de matières. Développement durable et territoires. Économie, géographie, politique, droit, sociologie 5(1), https://doi.org/10.4000/developpementdurable.10090.

BayLASD (2013): Zensusdatenbank 2011 - Ergebnisse aus der Zensusdatenbank dynamisch und individuell 2013 / Zensus database 2011 - Results from Zensus database dynamic and individually 2013, Bayrisches Landesamt für Statistik und Datenverarbeitung, https://ergebnisse.zensus2011.de/\#Home. (last access: July 2016).

BBSR, Bundesinstitut für Bau-, Stadt- und Raumforschung (2015b): Bericht zur Lage und Perspektive der Bauwirtschaft 2015. Bonn.

BBSR (2015a): Held, T; Waltersbacher, M.: Wohnungsmarktprognose 2030 [Housing market forecast 2030]. Bundesinstitut für Bau-, Stadt- und Raumforschung. In: BBSR-Analysen KOMPAKT 07/2015. Bonn.

BMVBS (Bundesministerium für Verkehr, Bau und Stadtentwicklung) (Ed.) (2018): Arbeitshilfen Recycling. Arbeitshilfen zum Umgang mit Bau- und Abbruchabfällen sowie zum Einsatz von RecyclingBaustoffen auf Liegenschaften des Bundes / Guidebook recycling. Guidebook for dealing with 
construction and demolition waste as well as for the use of recycled building materials on federal properties]. https://www.fib-bund.de/Inhalt/Richtlinien/BFRRecycling/ (last access: 01. April 2019).

Bölke, R. (2003): Das SAP-Implementierungsmodell SASPF der Bundeswehr [The SAP implementation model SASPF of the German Federal Armed Forces]. Diploma thesis. Fachhochschule Südwestfalen, Fachbereich Wirtschaftsinformatik, 2003, ISBN: 978-3838669564.

Bosch, G. und Rehfeld, D. (2003): Zukunftsstudie Baugewerbe Nordrhein-Westfalen / Future study construction industry Nordrhein-Westfalia. Endbericht. Gelsenkirchen.

Brunner, P.H., (2011). Urban mining, a contribution to reindustrializing the city. J.Ind. Ecol. 15 (3), 339-341, https://doi.org/10.1111/j.1530-9290.2011.00345.x.

Brunner, P.H; Lahner, T; Lohm, U.; de Haes, U.; Vijverberg, A.J.; Deistler, M.; Bacchini, P. (1998): Materials accounting as a tool for decision making in environmental policy (mac tempo), ENV4-CT960230, Summary final report, https://cordis.europa.eu/docs/publications/5166/51667541-6 en.pdf, last access: 24 May 2018

Buchert, M., Fritsche, U., Jenseit, W., Rausch, L., Deilmann, C., Schiller, G., Siedentop, S., and Lipkow, A. (2004). Material-flow related elements for a national concept of Sustainable Development - linking the construction and housing sector with the corresponding infrastructure/ Nachhaltiges Bauen und Wohnen in Deutschland: Stoffflussbezogene Bausteine für ein nationales Konzept der nachhaltigen Entwicklung - Verknüpfung des Bereiches Bauen und Wohnen mit dem komplementären Bereich „Öffentliche Infrastruktur". UBA, 412.

Buschmann, H., Daxbeck, H., Gassner, A., (2015). Das anthropogene Lager in der Steiermark Entwicklung eines Urban Mining Katasters (Projekt UMKAT) / The anthropogenic stock in the Steiermark region - Development of an urban mining catastre. Zukunftsakademie - Land OÖ Zukunftsthema Urban Mining, 15 September2015.

Busse, D. (2012): Nachhaltigkeitsaspekte in Theorie und Praxis der Entscheidungsfindung. Perspektiven institutioneller Steuerung in der Immobilienwirtschaft / Sustainability aspects in theory and practice in decision making - perspectives of institutional real estate mangement. Dissertation, Karlsruher Institut für Technologie (KIT). Karlsruhe. Gabler Verlag. Wiesbaden

Chinowsky, P., Diekmann, J. and Galotti, V. (2008): Social Network Model of Construction. Journal of Construction Engineering and Management 134 (10), pp. 804-812. http://ceae.colorado.edu/ diekmann/paul_victor_diek_\%20social_\%20networks.pdf (last access: 01. April 2019).

Clement, D.; Hammer, K.; Brunner, P.H.; Anger, L. (2009): "Quo vadis Baurestmassen? Nachhaltige Bewirtschaftung von Baurestmassen - ein Beitrag zur Ressourcenschonung" / Quo vadis building waste? Sustainable management of construction waste - a contribution to resource conservation, Proceedings "Nachhaltige Nutzung von Baurestmassen - Ein Beitrag zur Ressourcenschonung und Umweltverträglichkeit im Bauwesen", 13. November 2009, Wien.

Cochran, K., Townsend, T., Reinhart, D., Heck, H., 2007. Estimation of regional building-related C\&D debris generation and composition: case study for Florida, US. Waste Manage. 27 (7), 921-931, 
https://doi.org/10.1016/j.wasman.2006.03.023.

Coelho, A., de Brito, J., 2011a. Distribution of materials in construction and demolition waste in Portugal. Waste Management \& Research, 29(8), 843-853, https://doi.org/10.1177/0734242X10370240.

Coelho, A., de Brito, J., 2011b. Generation of construction and demolition waste in Portugal. Waste Management \& Research, 29(7), 739-750. https://doi.org/10.1177/0734242X11402253.

Condeixa, K., Haddad, A., Boer, D. (2017): Material flow analysis of the residential building stock at the city of Rio de Janeiro, Journal of Cleaner Production, Volume 149, 15 April 2017, Pages 1249-1267, https://doi.org/10.1016/j.jclepro.2017.02.080.

Crawford, R. H., Mathur, D., Gerritsen, R. (2017): Barriers to Improving the Environmental Performance of Construction Waste Management in Remote Communities, Procedia Engineering, Volume 196, 2017, pp. 830-837, https://doi.org/10.1016/j.proeng.2017.08.014

Daxbeck, H., Buschmann, H., Gassner, A., Kapfenberger-Pock, A., 2015. Das anthropogene Lager in der Steiermark - Entwicklung eines Urban Mining Katasters: Land Steiermark inklusive Fallstudie Graz. Projekt UMKAT - Endbericht / The anthropogenic stock in the Steiermark region - development of an urban mining catastre including a case study in Graz - Final report of project UMKAT, http://www.rma.at/sites/new.rma.at/files/Projekt\%20UMKAT\%20-

\%20Endbericht\%20(Vers.\%201.0a).pdf.

Deilmann, C.; Behnisch, M.; Dirlich, S.; Gruhler, K.; Hagemann, U.; Petereit R.; Kunz, C.; Petereit, K. (2013): Systematische Datenanalyse im Bereich der Nichtwohngebäude - Erfassung und Quantifizierung von Energieeinspar- und $\mathrm{CO}_{2}$-Minderungspotenzialen / Systematic data anlysis of nonresidential buildings - Identification and quantification of energy and $\mathrm{CO}_{2}$ reduction potentials. LeibnizInstitut für ökologische Raumentwicklung e.V. (IÖR); Ingenieurbüro Petereit. Im Auftrag des BMVBS. Dresden, Göldenitz, Berlin, http://www.irbnet.de/daten/baufo/20138036007/DL_ON272013.pdf, last access: 05 Dec 2018.

Deilmann, C.; Krauß, N.; Gruhler, K.; Reichenbach, J. (2014): Sensitivitätsstudie zum Kreislaufwirtschaftspotenzial im Hochbau. Endbericht / Sensitivity study on circular economy potential of structural engineering, Zukunft Bau, im Auftrag von BBSR, Leibniz-Institut für ökologische Raumentwicklung e.V. (IÖR); Intecus GmbH. Im Auftrag des BBSR und BBR. INTECUS GmbH Abfallwirtschaft und umweltintegratives Management, Dresden.

De Melo, A.B.; Goncalves, A.F.; Martins, I.M. (2011). Construction and demolition waste generation and management in Lisbon (Portugal). Resour. Conserv. Recycl. 55 (12), 1252-1264, https://doi.org/10.1016/j.resconrec.2011.06.010.

Destatis (2012): Bauen und Wohnen: Mikrozensus - Zusatzerhebung 2010. Bestand und Struktur der Wohneinheiten. Wohnsituation der Haushalte. / Construction and living: Mikrozensus - Additional data 2010. Stock and structure of residential units and situation of households. Wiesbaden:

Statistisches Bundesamt; 2012. 
Destatis (2015): Pötzsch O., Rößger F.: Bevölkerung Deutschlands bis 2060; 13. koordinierte Bevölkerungsvorausberechnung / Demographics in Germany until 2060, 13. Coordinated demographic projection; Statistisches Bundesamt; Wiesbaden, 2015

Destatis (2016): Umwelt /Environment - Erhebung über die Abfallerzeugung / Survey on waste generation - Ergebnisbericht / Report 2014, https://www.destatis.de/DE/Publikationen/Thematisch/UmweltstatistischeErhebungen/Abfallwirtsc haft/Abfallerzeugung5321601149004.pdf? blob=publicationFile, (last access: 23 March 2018)

Destatis (2017): Anstieg der Siedlungs- und Verkehrfläche / Increase in settlement and traffic area, Fachserie 3, Reihe 5.1, Bodenfläche nach Art der tatsächlichen Nutzung / Floor area by type of actual us2, 2016),

https://www.destatis.de/DE/ZahlenFakten/Wirtschaftsbereiche/LandForstwirtschaftFischerei/Flaech ennutzung/FlaechennutzungAktuell.html and https://www.destatis.de/DE/Publikationen/Thematisch/LandForstwirtschaft/Flaechennutzung/Bode nflaechennutzung.html (last access: 06 March 2019).

Destatis (2018a): Umwelt / Environment, Abfallentsorgung / Waste disposal 2016, Fachserie 19 Reihe 1 ,

https://www.destatis.de/DE/Publikationen/Thematisch/UmweltstatistischeErhebungen/Abfallwirtsc haft/Abfallentsorgung2190100157004.pdf? blob=publicationFile (last access: 15 February 2019)

Destatis (2018b): Umweltstatistische Erhebungen, Abfallwirtschaft, Abfallbilanz 2016 / Environmental statistics / Waste management industry / Waste balance 2016, https://www.destatis.de/DE/Publikationen/Thematisch/UmweltstatistischeErhebungen/Abfallwirtsc haft/AbfallbilanzPDF_5321001.pdf?_blob=publicationFile (last access: 15 February 2019)

Diederichs, C. J. (2012): Bauwirtschaft und Baubetrieb. Unternehmensführung / Construction management. In: K. Zilch, C. J. Diederichs, R. Katzenbach und K. J. Beckmann (Hrsg.): Handbuch für Bauingenieure. Technik, Organisation und Wirtschaftlichkeit. 2., akt. Auflage. Springer, Berlin/Heidelberg, S. 569-622, https://doi.org/10.1007/978-3-642-14450-9.

Ding, T., Xiao, J. (2014): Estimation of building-related construction and demolition waste in Shanghai, Waste Management, Volume 34, Issue 11, November 2014, Pages 2327-2334, https://doi.org/10.1016/j.wasman.2014.07.029

Dirlich, S.; Gruhler, K.; Deilmann, C.; Petereit R.; Kunz, C.; Petereit, K. (2011): Typologie und Bestand beheizter Nichtwohngebäude in Deutschland / Typology and stocks of heated non-residential buildings in Germany. Leibniz-Institut für ökologische Raumentwicklung e.V. (IÖR); Ingenieurbüro Petereit. Im Auftrag des BMVBS, BBSR und BBR. Dresden, Göldenitz.

Duan, H., Wang, J., Huang, Q. (2015): Encouraging the environmentally sound management of C\&D waste in China: An integrative review and research agenda, Renewable and Sustainable Energy Reviews, Volume 43, March 2015, Pages 611-620, https://doi.org/10.1016/j.rser.2014.11.069

Dürkoop, A., Brandstetter, C.P., Gräbe, G., Rentsch, L., 2016. Innovative Technologien für Ressourceneffizienz - Strategische Metalle und Mineralien /Innovative Technologies for resource efficiency. Fraunhofer Verlag, Stuttgart, 440 Seiten. 
European Commission (2014): Living well, within the limits of our planet: 7th EAP - the new general Union Environment Action Programme to 2020, 4 pp.

Figge, F.; Hahn, T.; Schaltegger, S. und Wagner, M. (2002): The Sustainability Balanced Scorecard linking sustainability management to business strategy. Business Strategy and the Environment 11 (5), S. 269-284, https://doi.org/10.1002/bse.339.

Fishman, T., Schandl, H., Tanikawa, H. (2015): The socio-economic drivers of material stock accumulation in Japan's prefectures, Ecological Economics, Volume 113, May 2015, Pages 76-84, http://doi.org/10.1016/j.ecolecon.2015.03.001

Gontia, P., Nägeli, C., Rosado, L., Kalmykova, Y., Österbring, M. (2018): Material-intensity database of residential buildings: A case-study of Sweden in the international context, Resources, Conservation and Recycling, Volume 130, March 2018, Pages 228-239, https://doi.org/10.1016/j.resconrec.2017.11.022

Görg, H. (1997). Entwicklung eines Prognosemodells für Bauabfälle als Baustein von Stoffstrombetrachtungen zur Kreislaufwirtschaft im Bauwesen / Development of a projection model for C\&D waste as part of mass flow analyses of circular economy in the construction sector. TU Darmstadt, Darmstadt

Gruhler, K.; Böhm, R.; Deilmann, C.; Schiller, G. (2002): Stofflich-energetische Gebäudesteckbriefe. Gebäudevergleiche und Hochrechnungen für Bebauungsstrukturen / Material and energetic building passes - Building comparisons and extrapolations for building structures. Hg. v. Institut für ökologische Raumentwicklung e. V. Dresden.

Gruhler, K.; Böhm, R. (2011b): Ressourcenbezogene Kennwerte von Nichtwohngebäuden - Analyse und Aufarbeitung von Daten der Statistik „Bauen und Wohnen“ / Resource-related indicators of nonresidential buildings - analysis and data preparation of statistics, Leibniz-Institut für ökologische Raumentwicklung e.V. (IÖR), Dresden. Fraunhofer IRB Verlag, Stuttgart.

Gruhler, K; Böhm, R. (2011a): Auswirkungen des demografischen Wandels auf das Stofflager und die Stoffflüsse des Wohngebäudebestandes - Deutschland 2050 / Effects of demographic change and material flows in the residential building stock. Leibniz-Institut für ökologische Raumentwicklung e.V. (IÖR), Dresden. Fraunhofer IRB Verlag, Stuttgart.

Harlfinger, T. (2006): Referenzvorgehensmodell zum Redevelopment von Bürobestandsimmobilien [Reference procedure model for the redevelopment of existing office properties]. Books on Demand $\mathrm{GmbH}$, Norderstedt, Dissertation, ISBN: 978-3833437502.

Hassan, S. H., Ahzahar, N., Azrizal, M., Eman, J. (2012): Waste Management Issues in the Northern Region of Malaysia, Procedia - Social and Behavioral Sciences, Volume 42, 2012, Pages 175-181, https://doi.org/10.1016/j.sbspro.2012.04.179

Hedemann, J. et al. (2017): Kartierung des anthropogenen Lagers in Deutschland: Entwicklung eines dynamischen Stoffstrommodells und Aufbau einer Datenbank zur Prognose des Sekundärrohstoffaufkommens (KartAL II) / Mapping of the anthropogenic stock in Germany: Development of a dynamic material flow model and of a database for the forecast of the secondary raw material supply, Abschlussbericht / Final report, 
https://www.umweltbundesamt.de/sites/default/files/medien/1410/publikationen/2017-0804 texte 58-2017 kartalii.pdf (last access: 03 May 2018)

Hiete, M., Stengel, J., Ludwig, J., Schultmann, F. (2011): Matching construction and demolition waste supply and recycling demand: a regional management chain model, Building Research \& Information, 39:4, pp. 333.351, https://doi.org/10.1080/09613218.2011.576849

Hong, L., Zhou, N., Feng, W., Khanna, N., Fridley, D., Zhao, Y., Sandholt, K. (2016): Building stock dynamics and its impacts on materials and energy demand in China, Energy Policy, Volume 94, July 2016, Pages 47-55, https://doi.org/10.1016/i.enpol.2016.03.024

IÖR (2018): Physis der gebauten Umwelt - Informationsportal zu Bauwerksdaten / Physics of the built environment - information platform for built structures, http://bdat.ioer.eu, last access: 02.05.2018

IWU (2012): TABULA - Scientific Report Germany - Further Development of the German Building Typology. 2012.

IWU (2011): Deutsche Gebäudetypologie - Beispielhafte Maßnahmen zur Verbesserung der Energieeffizienz von typischen Wohngebäuden / German building typology - Exemplary measures for energy efficiency improvements of typical residential buildings. Institut Wohnen und Umwelt; 2011.

IWU (2005): Dokumentation Deutsche Gebäudetypologie - Systematik und Datensätze / Documentation - German Building Typology - Systematics and data sets; Stand: 22. Juni 2005. Institut Wohnen und Umwelt GmbH (IWU), Darmstadt.

IWU (1994): Empirische Überprüfung der Möglichkeiten und Kosten, im Gebäudebestand und bei Neubauten Energie einzusparen und die Energieeffizienz zu steigern (ABL und NBL) / Empirical review of the possibilities and costs of saving energy and increasing energy efficiency in existing buildings and new buildings. Endbericht / Final report für die „Deutsche Bundesstiftung Umwelt“ in Kooperation mit der Enquete-Kommission „Schutz der Erdatmosphäre“ des Deutschen Bundestages. Darmstadt.

Jin, R; Li, B.; Zhou, T. Wanatowski, D.; Piroozfar, P. (2017): An empirical study of perceptions towards construction and demolition waste recycling and reuse in China, Resources, Conservation and Recycling, Volume 126, November 2017, Pages 86-98,

https://doi.org/10.1016/j.resconrec.2017.07.034

Kaplan, R.S. and Norton, D.P. (1992): The balanced scorecard - Measures that drive performance. Harvard Business Review, January-February 1992 Issue, Reprint 92105, https://steinbeisbi.de/images/artikel/hbr 1992.pdf

Klauß S, Kirchhof W, Gissel J. (2009): Katalog regionaltypischer Materialien im Gebäudebestand mit Bezug auf die Baualtersklasse und Ableitung typischer Bauteilaufbauten / Catalog of regional materials in the building stock with reference to the construction period and derivation of typical component structures, Bericht. Kassel: Zentrum für Umweltbewusstes Bauen (ZUB); https://www.zub-systems.de/sites/default/files/downloads/Deutschlandkarte-2009-10.pdf, 2009 (last access: 19. April 2018). 
Kleemann, F., Lederer, J., Rechberger, H., Fellner, J. (2016): GIS-based Analysis of Vienna's Material Stock in Buildings. Journal of Industrial Ecology 21 (2), 368-380. https://doi.org/10.1111/jiec.12446.

Kleemann, F., Lederer, J., Fellner, J. (2015): Buildings as an Urban Mine - The case study of Vienna, in: Mining the Technosphere. Drivers and Barriers, Challenges and Opportunities. International Workshop. Mining the Technosphere, Wien.01.-02.10.2015, pp. 105-108.

Kleemann, F., Lederer, J., Aschenbrenner, P., Rechberger, H., Fellner, J. (2014). A method for determining buildings' material composition prior to demolition. Build. Res. Info. 44 (1), 51-62, http://dx.doi.org/10.1080/09613218.2014.979029, print version from 2016.

Knappe, F., Lansche, J. (2010). Optimierung der Verwertung mineralischer Bauabfälle in BadenWürttemberg / Optimization of the recycling of mineral C\&D waste in Baden-Württemberg; Study on behalf of Umweltministerium Baden-Württemberg, IFEU Institute Heidelberg.

Knappe, F., Dehoust, G., Petschow, U. und Jakubowski, G. (2012): Steigerung von Akzeptanz und Einsatz mineralischer Sekundärrohstoffe unter Berücksichtigung schutzgutbezogener und anwendungsbezogener Anforderungen, des potenziellen, volkswirtschaftlichen Nutzens sowie branchenbezogener, ökonomischer Anreizinstrumente / Increase of acceptance and use of mineral secondary raw materials, taking into account resource protection and application requirements, potential economic benefits as well as sector-specific, economic incentive instruments. UBA, DessauRoßlau. (Hrsg). http://www.uba.de/uba-info-medien/4305.html (last access: 19.4.2018).

Knappe, F.; Reinhardt, J.; Bergmann, T.; Mottschall, M.; Keck, I.; Köstlin, S. (2015): Substitution von Primärrohstoffen im Straßen- und Wegebau durch mineralische Abfälle und Bodenaushub Stoffströme und Potenziale unter Berücksichtigung von Neu-, Aus- und Rückbau sowie der Instandsetzung / Substitution of primary raw materials in road construction with mineral waste and excavated soil - mass flows and potentials in new construction, repair and dismantling. Ifeu-Institut; Öko-Institut; Keck-Informationstechnologie. Im Auftrag des Umweltbundesamtes. UBA, DessauRoßlau, http://www.bmu.de/fileadmin/Daten BMU/Pools/Forschungsdatenbank/fkz 371233324 primaer rohstoffe strassenbau bf.pdf (last access: 01 June 2018)

Knoeri, C.; Binder, C.; Althaus, H.-J. (2011): Decisions on recycling: Construction stakeholders' decisions regarding recycled mineral construction materials, Resources, Conservation and Recycling, Volume 55, Issue 11, September 2011, Pages 1039-1050, https://doi.org/10.1016/j.resconrec.2011.05.018

Kohler, N. and Hassler, U. 2002. The building stock as a research object. Building Research \& Information, 30(4): 226-236, https://doi.org/10.1080/09613210110102238.

Kohler, N. and Yang, W., 2007. Long-term management of building stocks. Build. Res. Inf. 35, 351362, https://doi.org/10.1080/09613210701308962.

KRW-Bau (2017): Mineralische Bauabfälle Monitoring 2014 - Bericht zum Aufkommen und zum Verbleib mineralischer Bauabfälle im Jahr 2014 / Mineral C\&D Waste Monitoring 2014 - Report on the occurrence and fate of mineral construction waste in 2014, Kreislaufwirtschaft Bau, http://kreislaufwirtschaft-bau.de/Arge/Bericht-10.pdf (last access: 24 March 2018) 
Lee, Eun-Kyung (2013): Umweltrechtlicher Instrumentenmix und kumulative Grundrechtseinwirkungen / Environmental instrument mix and cumulative fundamental rights impacts. Überlegungen am Beispiel des Energierechts / Considerations in energy policy. Mohr Siebeck (Studien zum europäischen und deutschen öffentlichen Recht, 4), Tübingen, S. 250, zugl. Dissertation Freie Universität Berlin.

Littau, P. (2015): Managing Stakeholders in Megaprojects. University of Leeds. Leeds. https://bib.irb.hr/datoteka/768614. Managing Stakeholders in Megaprojects.pdf (last access: 01. April 2019).

Lu, W., Tam, V.W.Y. (2013): Construction waste management policies and their effectiveness in Hong Kong: a longitudinal review. Renew. Sustain. Energy Rev. 23, 214-223, https://doi.org/10.1016/i.rser.2013.03.007

Lu, W.; Chen, X.; Ho, D. C.W.; Wang, H. (2016): Analysis of the construction waste management performance in Hong Kong: the public and private sectors compared using big data, Journal of Cleaner Production 112 (2016) 521-531, http://dx.doi.org/10.1016/j.jclepro.2015.06.106

Marzouk, M.; Azab S. (2014): Environmental and economic impact assessment of construction and demolition waste disposal using system dynamics ${ }_{\llcorner}$Resources, Conservation and Recycling, Volume 82, 2014, pp. 41-49, https://doi.org/10.1016/j.resconrec.2013.10.015

Mastrucci, A.; Marvuglia, A.; Popovici, E.; Leopold, U.; Benetto, E. (2017): Geospatial characterization of building material stocks for the life cycle assessment of end-of-life scenarios at the urban scale, Resources, Conservation and Recycling, Volume 123, August 2017, Pages 54-66, https://doi.org/10.1016/j.resconrec.2016.07.003

Menegaki, M.; Damigos, D. (2018): A review on current situation and challenges of construction and demolition waste management, Current Opinion in Green and Sustainable Chemistry, Volume 13, October 2018, Pages 8-15, https://doi.org/10.1016/j.cogsc.2018.02.010

Mikrozensus (2010): Datenangebot | Mikrozensus 2010, statistische Ämter des Bundes und der Länder, Forschungsdatenzentren, http://www.forschungsdatenzentrum.de/bestand/mikrozensus/cf/2010/index.asp (last access: 20 August 2018)

Mitchell, R.K., Agle, B.R. and Wood, D.J. (1997): Toward a Theory of Stakeholder Identification and Salience: Defining the Principle of Who and What Really Counts. Academy of Management Review 22 (4), S. 853-886. https://www.jstor.org/stable/pdf/259247.pdf (last access: 04. July 2018).

Müller, R. C.; Schamber, O.; Volk, R.; Schultmann, F. (2017): A Stakeholder-Based Assessment Model (SAM) for Resource -Efficiency Measures in the Construction Industry, Proceedings of the World Sustainable Built Environment Conference 2017: Transforming Our Built Environment through Innovation and Integration: Putting Ideas into Action, Hong Kong, 5-7 June 2017, pp. 833-839, ISBN: 978-988-77943-0-1, https://publikationen.bibliothek.kit.edu/1000072058/4249999

Müller, F. (2016): Das anthropogene Lager / The anthropogenic stock, Umweltbundesamt https://www.umweltbundesamt.de/themen/abfall-ressourcen/abfallwirtschaft/urban-mining/dasanthropogene-lager\#textpart-5 (last access: 02 July 2018) 
Müller, E., Hilty, L.M., Widmer, R., Schluep, M., Faulstich, M. (2014). Modeling metal stocks and flows: a review of dynamic material flow analysis methods. Environ. Sci. Technol. 48 (4), 2102-2113, https://doi.org/10.1021/es403506a.

Müller, D.B., Bader, H.P., Baccini, P. (2004): Long-term coordination of timber production and consumption using a dynamic material and energy flow analysis. J. Ind. Ecol. 8 (3), 65-88, https://doi.org/10.1162/1088198042442342

Naber, E.; Volk, R.; Schultmann, F. (2017): Assessing building related energy demand and buildingbound material masses of residential and non-residential building stocks .2017. International Conference on Advances on Sustainable Cities and Buildings Development, SB-LAB 2017, Nov. 15-17, 2017, 241-253, Green Lines Institute for Sustainable Development, Porto, Portugal.

Olander, S. (2006): External stakeholder analysis in construction project management. Lund University. Lund. http://vpp.sbuf.se/Public/Documents/ProjectDocuments/D3ACFBE9-0622-43FE8BFC-

F313FD2B25AB\%5CFinalReport\%5CSBUF\%2011346\%20Slutrapport\%20Doktorsavhandling\%20Extern al\%20Stakeholder\%20Analysis\%20in\%20Construction\%20Management.pdf (last access: 01.04.2019).

Olander, S. (2007): Stakeholder impact analysis in construction project management. Construction Management and Economics 25 (3), S. 277-287, https://doi.org/10.1080/01446190600879125.

Olander, S. and Landin, A. (2005): Evaluation of stakeholder influence in the implementation of construction projects. International Journal of Project Management 23 (4), S. 321-328.

Olander, S. and Landin, A. (2008): A comparative study of factors affecting the external stakeholder management process. Construction Management and Economics 26 (6), S. 553-561.

Ortlepp, R.; Gruhler, K.; Schiller, G.; Deilmann, C. (2015a): The other 'half of the city' - analysis of non-residential building stock and its material, In: Gibberd, J. [Ed.]; Conradie, D.C.U. [Ed.]: Proceedings of the Smart and Sustainable Built Environment (SASBE) Conference 2015, University of Pretoria, Pretoria, South Africa, 9.-11.12.2015. Pretoria, 2015, S. 271-280,

https://www.researchgate.net/publication/289202266_The_other_half_of_the_city__analysis_of_non-residential_building_stock_and_its_materials

Ortlepp, R.; Gruhler, K.; Schiller, G. (2015b): Rohstofflagerstätte im Nichtwohngebäudebestand Bestandsschätzungsverfahren zur Unterstützung eines strategischen Urban Minings / Raw Material Banks in Non-Residential Property Stock - Stock Assessment Process to Support Strategic Urban Mining, In: Deilmann, C.; Gruhler, K.: Materialaufwand von Nichtwohngebäuden. Verfahrensschritte zur Abbildung der Ressourceninanspruchnahme des Nichtwohnbau-Bestandes. Stuttgart: Fraunhofer IRB Verlag, 2015, (Reihe Wissenschaft; 45), S.137-149.

Ortlepp, R.; Gruhler, K.; Schiller, G. (2016): Material stocks in Germany's non-domestic buildings: a new quantification method, Building research and information, Vol. 44(8), pp. 840-862, https://doi.org/10.1080/09613218.2016.1112096

Ortlepp, R.; Gruhler, K.; Schiller, G.; Ortlepp, S. (2017): Grundlagen für materialeffizientes Planen und Bauen - Baustoffzusammensetzung des deutschen Nichtwohngebäudebestands / Fundamentals of 
material-efficient planning and construction - building material composition of the German nonresidential building stock. In: Bautechnik 94 (1), S. 10-18, https://doi.org/10.1002/bate.201600022.

Ortlepp, R.; Gruhler, K.; Schiller, G. (2018): Materials in Germany's domestic building stock: calculation model and uncertainties, Building Research and Information, Vol. 46(2), pp. 164-178, https://doi.org/10.1080/09613218.2016.1264121

Oyedele, L.; Ajayi, S.; Kadiri, K. (2014): Use of recycled products in UK construction industry: An empirical investigation into critical impediments and strategies for improvement, Resources, Conservation and Recycling, Volume 93, December 2014, Pages 23-31, https://doi.org/10.1016/j.resconrec.2014.09.011

Park, J. and Tucker, R. (2017): Overcoming barriers to the reuse of construction waste material in Australia: a review of the literature, International Journal of Construction Management, Volume 17, 2017, Issue 3, https://doi.org/10.1080/15623599.2016.1192248

Persson, U. and Olander, S. (2004): Methods to estimate stakeholder views of sustainability for construction projects. The 21th Conference on Passive and Low Energy Architecture, 19-22 September, 2004. Eindhoven.

https://www.researchgate.net/profile/Urban Persson/publication/253744025 Methods to Estimat e Stakeholder Views of Sustainability for Construction Projects/links/54c600300cf2911c7a56b6b 4.pdf (last access: 04. July 2018).

Persson, U. (2009): Managment of sustainability in construction works. Dissertation. Lund Institute of Technology, Lund University. Lund. Division of Construction Management.

Polat, G., Damci, A., Turkoglu, H., Gurgun A.P. (2017): Identification of Root Causes of Construction and Demolition (C\&D) Waste: The Case of Turkey, Procedia Engineering, Volume 196, 2017, Pages 948-955, https://doi.org/10.1016/i.proeng.2017.08.035

Rechberger, H., Clement, D. (2011): Urban Mining - städtebauliche Rohstoff-Potenziale / Urban Resource Potentials. In: Recycling und Rohstoffe - Band 4, vol. 4, Thomé-Kozmiensky (ed.), TK Verlag; 2011, ISBN: 978-3-935317-67-2.

Rentz, O.; Pitzini-Dué, B.; Schultmann, F. (1998a): Audit et déconstruction sélective d'un bâtiment à ossature métallique / Audit and selective deconstruction of a metal frame building, Internal Report, French-German Institute for Environmental Research, Karlsruhe (unpublished).

Rentz, O.; Ruch, M.; Schultmann, F.; Sindt, V.; Zundel, T.; Charlot-Vadieu, C.; Vimond, E. (1998b): Selektiver Gebäuderückbau und konventioneller Abbruch: technisch wirtschaftliche Analyse eines Pilotprojektes / Selective and conventional demolition: technical economic analysis of a pilot project, Hüthig Jehle Rehm, ISBN 3-609-652802.

Rentz, O.; Schultmann, F.; Seemann, A. (1998c): Rückbau des staatlichen Aufbaugymnasiums Rottweil - Gebäudeauditierung, Rückbau- und Verwertungsplanung / Dismantling of the public grammar school Rottweil - Building auditing, dismantling and recycling planning. Endbericht eines Forschungsvorhabens im Auftrag des Staatlichen Vermögens- und Bauamtes Rottweil / Final Report of a research project on behalf of the Rottweil State Property and Construction Office (unpublished). 
Rentz, O.; Ruch, M.; Schultmann, F.; Sindt, V.; Zundel, T. (1998d): Deconstruction selective - etude scientifique de la deconstruction selective d'une immeuble a Mulhouse / Selective deconstruction scientific study of the selective deconstruction of a building in Mulhouse. Société Alpine de Publications, Grenoble.

Rentz, O.; Pitzini-Dué, B.; Zundel, T. (1999): Chantier de déconstruction sélèctive, Lycée Xavier Bichat, Nantua, réalisation et intégration d'un audit du bâtiment avant déconstruction au dossier de consultation des entreprises, planification, réalisation et suivi des travaux / Selective deconstruction site - Lycee Xavier Bichat, Nantua, Realization and integration of an audit of the building before deconstruction to the file of consultation of the companies, Institut Franco-Allemand de Recherche sur l'Environnement, 1999 - 176 pages.

Rouvreau, L.; Michel, P.; Monfort, D.; Jayr, E.; Morice. J. (2013): L'analyse systémique du métabolisme territorial, un outil pour favoriser le recours aux ressources secondaires dans le domaine du BTP / Systemic analysis of territorial metabolism, a tool to promote the use of secondary resources in the field of construction. Colloque International Futurs urbains, Jan 2013, PARIS, France. <hal-00788373>, https://hal-brgm.archives-ouvertes.fr/hal-00788373/document

Saaty, T. (1990): How to make a decision. The analytic hierarchy process. European Journal of Operational Research 48 (1), S. 9-26.

Schebek, L., Schnitzer, B., Blesinger, D., Köhn, A., Miekley, B., Linke, H. J., Lohmann, A., Motzko, C., Seemann, A., (2017): Material stocks of the non-residential building sector: the case of the Rhine-Main area, Resources, Conservation and Recycling, Volume 123, August 2017, Pages 24-36, https://doi.org/10.1016/j.resconrec.2016.06.001

Schiller, G.; Deilmann, C.; Gruhler, K.; Röhm, P.; Reichenbach, J.; Baumann, J.; Günther, M. (2010): Ermittlung von Ressourcenschonungspotentialen bei der Verwertung von Bauabfällen und Erarbeitung von Empfehlungen zu deren Nutzung / Determination of resource conservation potentials in the utilization of building waste and development of recommendations for their use. Leibniz-Institut für ökologische Raumentwicklung e.V. (IÖR); Intecus GmbH. Im Auftrag des Umweltbundesamtes. In: Umweltbundesamt (UBA)-Texte 56/2010, ISSN: 1862-4804, Dessau-Roßlau, http://www.umweltbundesamt.de/publikationen/ermittlung-vonressourcenschonungspotenzialenbei, 2010

Schiller, G., Ortlepp, R., Krauß, N., Steger, S., Schütz, H., Acosta Fernández, J., Reichenbach, J., Wagner, J., Baumann, J., (2015): Kartierung des anthropogenen Lagers in Deutschland zur Optimierung der Sekundärrohstoffwirtschaft / Mapping of the anthropogenic stock in Germany to optimize the secondary raw material economy; UBA-Texte 83/2015, https://www.umweltbundesamt.de/sites/default/files/medien/378/publikationen/texte 832015 k artierung des anthropogenen lagers.pdf

Schiller, G., Müller, F., Ortlepp, R. (2017c): Mapping the anthropogenic stock in Germany: Metabolic evidence for a circular economy, Resources, Conservation and Recycling, Volume 123, August 2017, Pages 93-107, https://doi.org/10.1016/j.resconrec.2016.08.007

Schiller, G.; Gruhler, K.; Ortlepp, R. (2017a): Quantification of anthropogenic metabolism using spatially differentiated continuous MFA. In: Change and Adaptation in Socio-Ecological Systems 3 (2017) 1, pp. 119-132. https://doi.org/10.1515/cass-2017-0011. 
Schiller, G.; Gruhler, K.; Ortlepp, R. (2017b): Continuous material flow analysis approach for bulk nonmetallic mineral building materials applied to the German building sector. In: Journal of Industrial Ecology 21 (2017) 3, S. 673-688. http://dx.doi.org/10.1111/jiec.12595

Schiller, G.; Bräuer, A.; Westphal, M.; Zinkler, S.; Friederich, I.; Kramer-Heinke, K. (2016):

MinResource - Nachhaltiges Ressourcenmanagement von mineralischen Primär- und Sekundärbaustoffen. Dresden : Sächsisches Landesamt für Umwelt, Landwirtschaft und Geologie, 2016, S.98. https://publikationen.sachsen.de/bdb/artikel/13598

Schlomann, B.; Kleeberger, H.; Hardi, L.; Geiger, B; Pich, A.; Gruber, E.; Gerspacher, A.; Holländer, E.; Roser, A. (2015): Energieverbrauch des Sektors Gewerbe, Handel, Dienstleistungen (GHD) in Deutschland für die Jahre 2011 bis 2013 / Energy consumption of the sector trade, commerce, services (GHD) in Germany for the years 2011 to 2013. Fraunhofer ISI; IfE Technische Universität München; GfK Retail and Technology GmbH; IREES GmbH. Karlsruhe, München, Nürnberg.

Schmidt-Bleek, F.; Klüting, R. (1994): Wieviel Umwelt braucht der Mensch? MIPS - das Maß für ökologisches Wirtschaften / How much environment does a person need? MIPS - the indicator of ecological management. Birkhäuser, Berlin.

Seemann, A. (2003): Entwicklung integrierter Rückbau- und Recyclingkonzepte - Ein Ansatz zur Kopplung von Demontage, Sortierung und Aufbereitung / Development of integrated demolition and recycling concepts - An approach for coupling disassembly, sorting and processing, Dissertation. Deutsch-Französisches Institut für Umweltforschung, Universität Karlsruhe.

Sepp, H. (1996): Strategische Frühaufklärung - Eine ganzheitliche Konzeption aus ökologieorientierter Perspektive / Strategic Early Enlightenment - A holistic conception from an ecologyoriented perspective. Deutscher Universitätsverlag, Wiesbaden.

Serrand, M., Monfort-Climent, D., Vaxelaire, S., Michel, P., Gautier, A.-L. 2013. Projet ANR ASURET Approvisionnement en mateériaux de construction dans le départmement du Loiret et la Région Centre / ANR project ASURET - Supply of building materials in the Loiret department and Center region (tâche 4.3) - Rapport final BRGM/RP-62586-FR. 85 p., http://infoterre.brgm.fr/rapports/RP62296-FR.pdf

Song, Y., Wang, Y., Liu, F., Zhang, Y. (2017): Development of a hybrid model to predict construction and demolition waste: China as a case study, Waste Management, Volume 59, January 2017, Pages 350-361, https://doi.org/10.1016/j.wasman.2016.10.009

StaBaWü (2016): Abfallstatistik / Waste statistics; online: https://www.statistikbw.de/Umwelt/Abfall/a2d02.jsp; Statistisches Landesamt Baden-Württemberg /Federal Statistical Office Baden-Württemberg, (last visited: 09.02.2018)

Statistik Südwest (2016): Evaluation of the statistics service Südwest on behalf of ifeu. 2016.

Statistikportal (2019a): Entsorgung von Abfällen nach Abfallkategorien, https://www.statistikportal.de/de/entsorgung-von-abfaellen-nach-abfallkategorien, last access: 13.02.2019) 
Statistikportal (2019b): Entsorgung von Abfällen nach Art der Entsorgung, https://www.statistikportal.de/de/entsorgung-von-abfaellen-nach-art-der-entsorgung, last access: 13.02.2019).

Stephan, A., Athanassiadis, A. (2018): Towards a more circular construction sector: Estimating and spatialising current and future non-structural material replacement flows to maintain urban building stocks, Resources, Conservation and Recycling, Volume 129, February 2018, Pages 248-262, https://doi.org/10.1016/j.resconrec.2017.09.022

Streck, S. (2010): Leitbild Bau - Zur Zukunft des Planens und Bauens in Deutschland / Mission Statement Construction - The Future of Planning and Construction in Germany. In Bauingenieur, Band 85/2010. S 53-60.

Stürmer S., Kulle C. (2017): Untersuchung von Mauerwerksabbruch (verputztes Mauerwerk aus realen Abbruchgebäuden) und Ableitung von Kriterien für die Anwendung in Betonen mit rezyklierter Gesteinskörnung (RC-Beton mit Typ 2 Körnung) für den ressourcenschonenden Hochbau / Investigation of masonry demolition (plastered masonry from real demolition buildings) and derivation of criteria for use in concretes with recycled aggregates (RC concrete type 2 ) for resourcesaving building construction; HTWG Konstanz in Zusammenarbeit mit IAB Weimar und ifeu-Institut; im Auftrag der DBU. Oktober 2017

Tanikawa, H., Hashimoto, S., (2009). Urban stock over time: spatial material stock analysis using 4dGIS. Build. Res. Info. 37 (5-6), 483-502, http://dx.doi.org/10.1080/09613210903169394.

Tanikawa, H., Fishman, T., Okuoka, K., Sugimoto, K., (2015). The weight of society over time and space: a comprehensive account of the construction material stock of Japan, 1945-2010. J. Ind. Ecol. 19 (5), 778-791, https://doi.org/10.1111/jiec.12284.

UBA (2018b): Abfallaufkommen - Deutschlands Abfall / Waste generation - Germany's waste, https://www.umweltbundesamt.de/daten/ressourcen-abfall/abfallaufkommen\#textpart-1, based on data of: Statistisches Bundesamt (last access: 23 March 2018)

UBA (2018c): Bau-, Abbruch-, Gewerbe- und Bergbauabfälle / Construction, demolition, commercial and mining waste, https://www.umweltbundesamt.de/daten/ressourcenabfall/abfallaufkommen\#textpart-2, (last access: 23 March 2018)

Wadenpohl, F. (2011): Stakeholder-Management bei grossen Verkehrsinfrastrukturprojekten / Stakeholder management for large transport infrastructure projects. Dissertation ETH Zürich. vdf Hochschulverlag. Zürich. https://www.researchcollection.ethz.ch/bitstream/handle/20.500.11850/151876/eth-1099-02.pdf (last access: 04.July 2018).

Wang, Y.; Chen, P.-C.; Ma, H.-W.; et al. (2018): Socio-economic metabolism of urban construction materials: A case study of the Taipei metropolitan area, Resources Conservation and Recycling, Vol. 128, pp. 563-571, https://doi.org/10.1016/j.resconrec.2016.08.019

Winch, G.M. (2007): Managing project stakeholders. In: Morris, P.W.G. (Hrsg.): The Wiley guide to project, program \& portfolio management. Hoboken, NJ, S. 271-289. 
Wu, T.Z., Ann, T.W., Shen, L., Liu, G. (2014): Quantifying construction and demolition waste: an analytical review. Waste Manage. 34 (9), 1683-1692. https://doi.org/10.1016/j.wasman.2014.05.010

Wu, H., Duan, H., Zheng, L., Wang, J., Niu, Y., Zhang, G. (2016a): Demolition waste generation and recycling potentials in a rapidly developing flagship megacity of South China: Prospective scenarios and implications, Construction and Building Materials, Volume 113, 15 June 2016, Pages 1007-1016, https://doi.org/10.1016/j.conbuildmat.2016.03.130

Wu, H., Wang, J., Duan, H., Ouyang, L., Huang, W., Zuo, J. (2016b): An innovative approach to managing demolition waste via GIS (geographic information system): a case study in Shenzhen city, China, Journal of Cleaner Production, Volume 112, Part 1, 20 January 2016, Pages 494-503, https://doi.org/10.1016/j.jclepro.2015.08.096

Wünsche, M. (2015): BWL für IT-Berufe. Ein praxisorientierter Leitfaden für das kaufmännische Denken [Business Administration for IT Professions. A practice-oriented guideline for commercial thinking]. 3., aktualisierte Auflage. Springer, Wiesbaden.

Yang, W. and Kohler, N. (2008): Simulation of the Evolution of Chinese Building and Infrastructure Stock, Building Research and Information, vol. 36, no. 1, pp. 1-19, https://doi.org/10.1080/09613210701702883.

Yang, H., Xia, J., Thompson, J., Flower, R. (2017): Urban construction and demolition waste and landfill failure in Shenzhen, China, Waste Management, Volume 63, May 2017, Pages 393-396, https://doi.org/10.1016/j.wasman.2017.01.026

Zhao, W., Leeftink, R. B., Rotter, V.S. (2010): Evaluation of the economic feasibility for the recycling of construction and demolition waste in China-The case of Chongqing, Resources, Conservation and Recycling, Volume 54, Issue 6, April 2010, Pages 377-389,

https://doi.org/10.1016/j.resconrec.2009.09.003

Zheng, L., Wua, H., Zhang, H., Duan, H., Wang, J., Jiang, W., Dong, B., Liu, G., Zuo, J., Song, Q. (2017): Characterizing the generation and flows of construction and demolition waste in China, Construction and Building Materials, Volume 136, 1 April 2017, Pages 405-413,

https://doi.org/10.1016/j.conbuildmat.2017.01.055 